\begin{abstract}
ANÁLISE DA CAPACIDADE SELADORA E DA ADAPTAÇÃO MARGINAL DE TAMPÕES APICAIS CONFECCIONADOS COM DIFERENTES MATERIAIS, SOB A INFLUÊNCIA DE TRÊS TÉCNICAS DE OBTURAÇÃO DE CANAIS RADICULARES.
\end{abstract}

\begin{abstract}
Dissertação apresentada à Faculdade de Odontologia de Bauru, da Universidade de São Paulo, como parte dos requisitos para obtenção do título de Mestre em Odontologia, área de Endodontia.
\end{abstract}




\title{
ANÁLISE DA CAPACIDADE SELADORA E DA ADAPTAÇÃO MARGINAL DE TAMPÕES APICAIS CONFECCIONADOS COM DIFERENTES MATERIAIS, SOB A INFLUÊNCIA DE TRÊS TÉCNICAS DE OBTURAÇÃO DE CANAIS RADICULARES.
}

\begin{abstract}
Dissertação apresentada à Faculdade de Odontologia de Bauru, da Universidade de São Paulo, como parte dos requisitos para obtenção do título de Mestre em Odontologia, área de Endodontia.
\end{abstract}

Orientador: Prof. Dr. Ivaldo Gomes de Moraes 


\section{Orosco, Fernando Accorsi}

Análise da capacidade seladora e da adaptação

Or6a marginal de tampões apicais confeccionados com diferentes materiais, sob a influência de três técnicas de obturação. / Fernando Accorsi Orosco. - Bauru, 2007.

152 p. : il.; $30 \mathrm{~cm}$.

Dissertação (Mestrado) - Faculdade de Odontologia de Bauru. Universidade de São Paulo.

Orientador: Prof. Dr. Ivaldo Gomes de Moraes.

Aprovado pelo Comitê de Ética em Pesquisa em Seres Humanos da FOB-USP em 30 de novembro de 2005, sob o número 133/2005.

A cópia do parecer de aprovação e as cópias que indicam as alterações no título da dissertação encontram-se no capítulo “Apêndice”.

Autorizo, exclusivamente para fins acadêmicos e científicos, a reprodução total ou parcial desta Dissertação, por processos fotocopiadores e outros meios eletrônicos.

Bauru, 06 de fevereiro de 2007.

Assinatura: 


\section{Dados Curriculares \\ Fernando Accorsi Orosco}

Nascimento

Filiação

1997 2002

2002 2002

2003 2004

2005 2007

Associações
25 de janeiro de 1978

Jundiaí - SP

José Aparecido Orosco

Arlete Accorsi Orosco

Curso de Graduação em Odontologia -

Universidade de Fortaleza (UNIFOR) - CE

Curso de Aperfeiçoamento em Endodontia Universidade Camilo Castelo Branco - CE

Curso de Especialização em EndodontiaFaculdade de Odontologia de Bauru - USP

Curso de Pós graduação em Endodontia, nível de Mestrado, na Faculdade de Odontologia de Bauru - USP

SBPqO - Sociedade Brasileira de Pesquisa Odontológica

GRUBE - Grupo Bauruense de Endodontia 


\title{
AGRADECIMENTO ESPECIAL
}

\begin{abstract}
A DEUS, meu Pai Maior, pela vida, por todas as dificuldades que se fizeram presentes durante a realização do meu Mestrado, por ter colocado algumas pessoas tão maravilhosas na minha vida durante esse período, por me dar os melhores pais do mundo, por manter sempre viva em mim a chama da perseverança, pois algumas vezes eu achei que não conseguiria chegar até aqui e, mesmo quando achei que o Senhor havia se esquecido de mim, deixando de caminhar ao meu lado, na verdade o Senhor me carregava em Seus Braços, para permitir que eu recuperasse minhas forças e seguisse em frente.
\end{abstract}




\section{DEDICATÓRIA}

Ao meu pai, JOSÉ APARECIDO OROSCO, por ter dedicado grande parte de sua vida para dar a mim e à minha irmã uma vida tranqüila. Para mim, papai, o senhor é um grande vencedor, pois quem começou entregando jornal, aos 7 anos de idade, e se tornou diretor de uma grande multinacional, sendo sempre honesto e competente, só pode ser alguém muito especial. Costumo dizer que, se eu tiver $10 \%$ da sua capacidade profissional, serei um dos melhores na minha profissão. Obrigado por todo o seu amor, pelas suas broncas, que só me fizeram crescer e, principalmente, por fazer do meu sonho o seu sonho, permitindo que ele se tornasse realidade. Amo você!

À minha mãe, ARLETE ACCORSI OROSCO, que abdicou do seu trabalho para cuidar da família. Por todas as noites que a senhora passou ao meu lado, "estudando" comigo durante a minha graduação, e que me fez muita falta durante o Mestrado. Por não medir esforços para me ver sempre feliz, e por todo o amor que sempre teve por mim. A senhora, mamãe, também é um grande exemplo para mim; exemplo de bondade, de dedicação, de caráter. Obrigado por tudo o que fez por mim. Amo você!

A toda minha família, em especial à minha querida irmã TATIANE, que eu tanto amo e quero muito bem.

À minha namorada, RENATA VASCONCELLOS SANCHEZ, pelo amor e pelo carinho que tem por mim. Por me mostrar e me fazer entender o real e verdadeiro sentido do amor e, principalmente, por acreditar em mim e me incentivar sempre na busca dessa conquista. Por compartilhar comigo as alegrias vividas e por estar ao meu lado nos momentos difíceis, apoiando me incondicionalmente. Obrigado por fazer de mim um homem melhor a cada dia. Você é muito especial, e eu tenho muita sorte por ter você em minha vida. Amo você!

\section{A VOCÊS, DEDICO ESPECIALMENTE ESTE TRABALHO!}




\section{DEDICATÓRIA}

Ao meu orientador, Prof. Dr. IVALDO GOMES DE MORAES. O senhor foi mais que um orientador para mim; foi meu pai, meu amigo, meu confidente, meu conselheiro....lembro me muito bem de que, ao vir para Bauru fazer minha especialização, fui aconselhado por um professor meu, de Fortaleza, a me paroximar do senhor, pois eu teria muito a aprender. Além de Endodontia, o senhor me ensinaria lições de vida. Ele estava certo! Não tenho palavras para agradecer todo o carinho, o respeito, os ensinamentos, enfim, tudo o que o senhor fez e tem feito por mim. Espero não tê lo decepcionado. O senhor tem um lugar especial guardado em meu coração. Foi uma honra poder compartilhar os seus conhecimentos e, especialmente, a sua amizade.

"Hoje, mais do que nunca, a humanidade necessita de homens conscientes, de homens que pensem e que saibam pensar bem, pois, sendo assim, estes poderão ensinar aos outros a fazer o mesmo e, desse modo, a humanidade voltará a encontrar algum dia a paz e a felicidade que perdeu."

Do livro "Introdução ao Conhecimento Logosófico"

C.B.G. Pecotche 


\section{AGRADECIMENTOS}

À melhor amiga da minha vida, PATRÍcIA ZANATTA ARANHA CONEGLIAN, mais do que amiga, minha "irmã de coração". Eu nunca poderei retribuir tudo o que você fez por mim. Você é uma das grandes responsáveis por eu conseguir terminar o Mestrado. Ser amigo quando tudo está bem é fácil, mas você sempre esteve ao meu lado nos momentos difíceis. Para mim foi um privilégio poder trabalhar com você, pois competência, determinação, responsabilidade e humildade são qualidades que você, irmãzinha, tem de sobra. Como já falei antes, toda a felicidade que eu desejo para mim, espero que você, o GUTO e os futuros pimpolhos possam ter em dobro. Obrigado por nunca desistir de mim. Tenho certeza de que a nossa amizade, não importa o que façam o tempo e a distância, será eterna.

À minha querida amiga SIMONE ELOÍZA SITA FAUSTINO, pelo carinho, pela sinceridade, pelo companheirismo, por compartilhar as minhas alegrias e as minhas tristezas. Obrigado por acreditar em mim e por fazer com que eu também acreditasse.

Ao grande amigo RONAN JACQUES REZENDE DELGADO, pela amizade sincera e honesta. Meu amigo, talvez eu nunca tenha lhe falado, mas a minha admiração por você é enorme. Admiro a sua determinação, a sua persistência, a sua capacidade de estar sempre de bom humor, mesmo em situações adversas, e a capacidade que você tem para superá las. Você é um grande exemplo para mim. Desejo, sinceramente, que você realize todos os seus sonhos. Obrigado por tudo!

À minha querida amiga CLARICE FERNANDES ELOY DA COSTA, pelo companheirismo, pelo bom humor contagiante, pelo que pude aprender trabalhando com você, pelo seu carinho. Espero que você tenha muito sucesso e seja muito feliz! 


\section{AGRADECIMENTOS}

Aos professores doutores CLÓVIS MONTEIRO BRAMANTE, ROBERTO BRANDÃO GARCIA, NORBERTI BERNARDINELI e ALCEU BERBERT, pela forma com que me receberam, desde o curso de especialização, e por todo o respeito e o carinho com que sempre me trataram. Obrigado pela oportunidade de aprender com vocês!

Às minhas amigas FLORA TÁVORA e GABRIELA VEDOLIN, pela longa e verdadeira amizade que nos une. Obrigado por fazerem parte da minha vida!

Ao meu sempre amigo e eterno "chefe", CARLOS QUIROZ, que, mesmo distante, sempre me acompanhou durante o Mestrado e torceu pelo meu sucesso.

A todos os meus colegas de Mestrado, que compartilharam comigo seus conhecimentos, suas experiências, e contribuíram para o meu crescimento profissional.

AOs professores MARCO ANTÔNIO HÚNGARO DUARTE, JOSÉ CARLOS YAMASHITA, ELIANE GULIN DE OLIVEIRA e SYLVIO DE CAMPOS FRAGA, da Universidade do Sagrado Coração - USC, Bauru, pela amizade, pelo respeito e pelos ensinamentos durante o Curso de Atualização em Endodontia. Ao Prof. Dr. José Carlos Yamashita, agradeço a oportunidade a mim oferecida, durante a VI Jornada de Odontologia da USC, de fazer parte, pela primeira vez, de uma banca examinadora.

À D. CARMINHA, FERNANDA, RENATA e GUILHERME, que sempre me trataram com muito carinho.

A todos os alunos de graduação da FOB USP, pois, ao me chamarem para ajudá los, nas clínicas e nos laboratórios, permitiram me dividir o que tenho de mais precioso, que é o meu, ainda pouco, conhecimento. Agradeço a oportunidade que tive de aprender com cada um de vocês e, principalmente, a confiança em mim depositada.

A todos os pós graduandos da FOB USP que eu tive o prazer de conhecer e com os quais pude aprender um pouco mais, em especial CARLA SIPERT, BRUNO VASCONCELOS, RAMIRO ORTIZ, ROBERTA GARCIA, THAÍS ACCORSI MENDONÇA, 
FERNANDA GOMES DE MORAES, NORBERTO JUÁREZ BROON, EDUARDO ANTUNES BORTOLUZZI, RENATO MENEZES, EVERDAN CARNEIRO, ULISSES XAVIER DA SILVA NETO, CHRISTIAN GIAMPIETRO BRANDÃO, JÁRCIO BALDI, ADRIANA LUSTOSA, FAUSTO VICTORINO E RICARDO BERNARDES.

À D. NEIDE, que sempre se preocupou comigo e, com apenas um abraço, fazia com que a saudade que eu sentia da minha família fosse minimizada.

Ao EDIMAURO, pela amizade, pelo carinho, pelos trotes que sempre me deu, por acabar se tornando meu "co orientador", pelas fotomicrografias feitas no microscópio eletrônico de varredura e por sempre estar disposto a me ajudar.

Aos demais funcionários de Departamento de Dentística, Endodontia e Materiais Dentários, SUELY, PATRÍCIA, CLEIDE, LÍGIA, NÉLSON, ALCIDES, MARIA e MAURO, por toda a atenção e solicitude que sempre demonstraram.

Ao OVÍDIO, funcionário da Disciplina de Bioquímica, pela amizade e pelo preparo da solução de Rodamina B a 0,2\%.

À amiga GISELE DA SILVA DALBEN, pela tradução do resumo para a língua inglesa.

Aos funcionários da Biblioteca da FOB USP, por todo o apoio na realização deste trabalho.

Ao Prof. Dr. JOSÉ ROBERTO PEREIRA LAURIS, pelo auxílio na realização da análise estatística.

À FACULDADE DE ODONTOLOGIA DE BAURU, da Universidade de São Paulo, na pessoa do seu Diretor, Prof. Dr. LUIZ FERNANDO PEGORARO.

À COMISSÃO DE PÓS GRADUAÇÃO da Faculdade de Odontologia de Bauru, na pessoa de sua Presidente, Prof ${ }^{a}$. Dra ${ }^{a}$. MARIA APARECIDA DE ANDRADE MOREIRA MACHADO.

Ao $\mathrm{CNPq}$, pela concessão da bolsa de estudos, que tornou possível a realização deste trabalho. 


\section{SUMÁRIO}

LISTA DE FIGURAS............................................................................. xiii

LISTA DE TABELAS........................................................................... XV

LISTA DE SÍMBOLOS E ABREVIATURAS............................................... x xviii

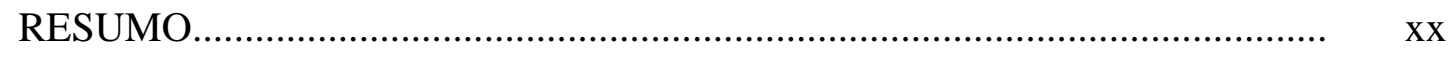

1 - INTRODUÇÃ

2 - REVISÃO DE LITERATURA............................................................. 9

2.1 - Pasta L \& C (Lopes \& Costa).......................................................... 9

2.2 - Cimento MTA (Agregado de Trióxido Mineral)................................. 11

2.3 - Cimento $\mathrm{CPM}^{\circledR}$ (Cimento Portland Modificado)................................ 33

2.4 - Cimento MBPc [Moraes e Berbert Pasta (cirurgia)]........................... 34

3 - PROPOSIÇÃO................................................................................. 41

4 - MATERIAL E MÉTODOS................................................................ 45

4.1 - Avaliação da capacidade seladora por meio da infiltração de Rodamina B

4.2 - Preparo dos espécimes para microscopia eletrônica de varredura........ 63

4.2.1 - Manobras prévias e montagem.................................................... 63

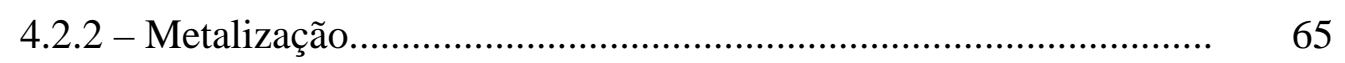

4.2.3 - Fotomicrografias em microscopia eletrônica de varredura e análise da adaptação dos materiais às paredes dentinárias.................................. 67

4.3 - Materiais utilizados........................................................................... $\quad 75$

4.3.1 - Pasta L \& C.............................................................................. 75

4.3.2 - Cimento MTA-Angelus ${ }^{\circledR}$ cinza................................................. 77

4.3.3 - Cimento CPM ${ }^{\circledR}$...................................................................... 79

4.3.4 - Cimento MBРc....................................................................... 81

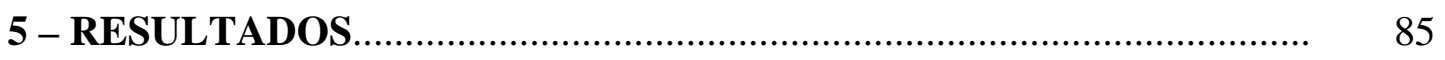

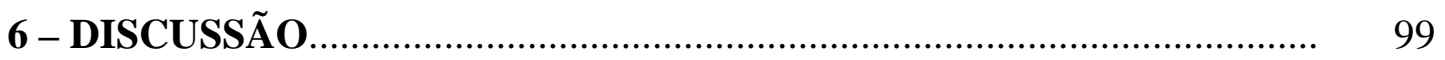

6.1 - Das metodologias........................................................................... 99

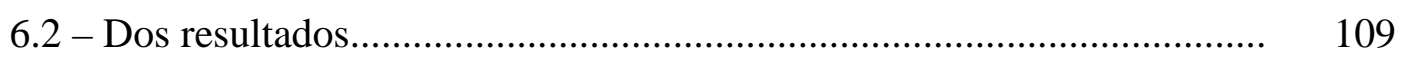

6.2.1 - Da avaliação da capacidade seladora por meio da infiltração de

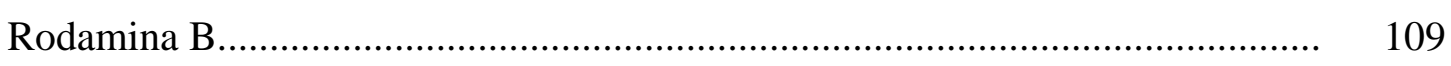

6.2.2 - Da análise da adaptação dos materiais às paredes dentinárias....... 112 
6.3 - Considerações gerais...................................................................... 113

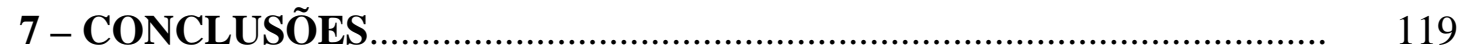

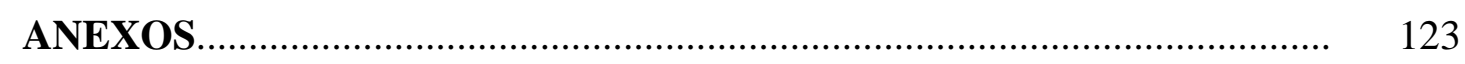

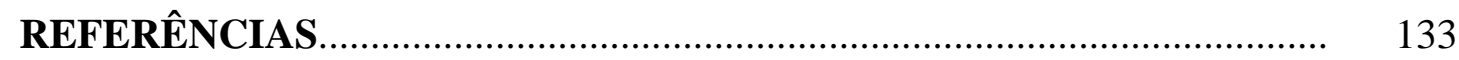

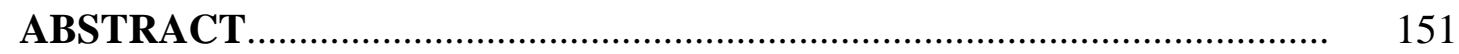

APÊNDICE 


\section{LISTA DE FIGURAS}

Quadro 1 Grupos e número de espécimes, em função dos materiais

Pág.

utilizados

Quadro 2 Subgrupos e número de espécimes, em função das técnicas obturadoras utilizadas.

Figura 1A Broca de Gates-Glidden número 1 ultrapassando o forame apical em $1 \mathrm{~mm}$

Figura 1B Ampliação da área apical observada na Figura 1A .

Figura 2A

Lima número 90 ultrapassando o forame apical em $1 \mathrm{~mm}$

Figura 2B Ampliação da área apical de outro dente mostrando o trespasse apical da lima, em $1 \mathrm{~mm}$.

Figura 3A Impermeabilização das raízes com araldite e esmalte para unhas..

Figura 3B Forame sem impermeabilização.

Figura 4A MTA-Angelus ${ }^{\circledR}$ cinza após a manipulação.

Compactação do cimento.

Figura 5A Proporcionamento do cimento MBPc..

Figura 5B

Homogeneização do cimento..

Figura 6A Dentes fixados em cera utilidade com os ápices voltados para cima.

Figura 6B Rodamina B a 0,2\% recobrindo completamente os ápices.

Figura 7 Fotografia dos dentes e do segmento da régua milimetrada para análise da infiltração de Rodamina B.

Figura 8 Medida da infiltração de Rodamina B feita no software Image Tool 3.0.

Figura 9 Hemiparte do dente seccionada transversalmente a $7 \mathrm{~mm}$ do ápice.

Figura 10 Fixação dos segmentos apicais para metalização. 
Figura 11 Segmentos apicais metalizados................................................... 67

Figura 12 Filme Neopan 100, ACROS, preto e branco.................................. 67

Figura 13A Tampão apical feito com MTA-Angelus ${ }^{\circledR}$ cinza............................ 69

Figura 13B Fotomicrografia mostrando a desadaptação do material em relação à parede dentinária............................................................. 69

Figura 13C Tampão apical feito com MTA-Angelus ${ }^{\circledR}$ cinza............................... 69

Figura 13D Fotomicrografia mostrando a adaptação do cimento em relação à

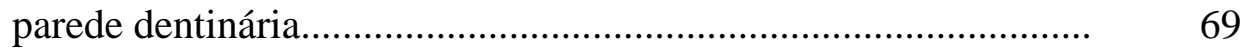

Figura 14A Tampão apical feito com $\mathrm{CPM}^{\circledR}$ …........................................... 71

Figura 14B Fotomicrografia mostrando a desadaptação do material em relação à parede dentinária.......................................................... 71

Figura 14C Tampão apical feito com CPM ${ }^{\circledR}$................................................ 71

Figura 14D Fotomicrografia mostrando a adaptação do cimento em relação à parede dentinária........................................................................ 71

Figura 15A Tampão apical feito com MBPc......................................................

Figura 15B Fotomicrografia mostrando a desadaptação do material em relação à parede dentinária........................................................... 73

Figura 15C Tampão apical feito com MBPc.................................................... 73

Figura 15D Fotomicrografia mostrando a adaptação do cimento em relação à

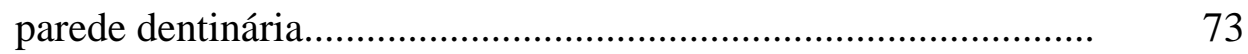

Figura 16 Medida da desadaptação marginal do tampão apical...................... 75

Figura $17 \quad$ Pasta L \& C............................................................................ $\quad 77$

Figura 18 Cimento MTA-Angelus ${ }^{\circledR}$ cinza..................................................... 77

Figura 19 Cimento $\mathrm{CPM}^{\circledR}$...................................................................... 79

Figura 20 Cimento MBPc...................................................................... 81 


\section{LISTA DE TABELAS}

Tabela 1 Médias de infiltração de Rodamina B a 0,2\%, em porcentagem,

Pág. considerando-se os materiais usados para a confecção dos tampões apicais e as técnicas obturadoras utilizadas.

Tabela 2 Avaliação da infiltração de Rodamina B a 0,2\% pelo teste nãoparamétrico de Kruskal-Wallis, quando considerada apenas a técnica da condensação lateral

Tabela 3 Comparação, pelo teste de Dunn, entre os materiais usados como tampão apical, para se determinar o nível de significância entre eles, considerando a técnica da condensação lateral.

Tabela 4 Avaliação da infiltração de Rodamina B a 0,2\% pelo teste nãoparamétrico de Kruskal-Wallis, quando considerada apenas a técnica híbrida de Tagger.

Tabela 5 Comparação, pelo teste de Dunn, entre os materiais usados como tampão apical, para se determinar o nível de significância entre eles, considerando a técnica híbrida de Tagger.

Tabela 6 Avaliação da infiltração de Rodamina B a 0,2\% pelo teste nãoparamétrico de Kruskal-Wallis, quando considerada apenas a técnica de injeção de guta-percha

Tabela 7 Comparação, pelo teste de Dunn, entre os materiais usados como tampão apical, para se determinar o nível de significância entre eles, utilizando a técnica de injeção de guta-percha.

Tabela 8 Avaliação da infiltração de Rodamina B a 0,2\% pelo teste nãoparamétrico de Kruskal-Wallis, quando considerado apenas o tampão apical feito com a pasta L \& C.............................................

Tabela 9 Comparação, pelo teste de Dunn, entre as técnicas obturadoras realizadas, para se determinar o nível de significância entre elas, considerando-se a pasta L \& C.

Tabela 10 Avaliação da infiltração de Rodamina B a 0,2\% pelo teste nãoparamétrico de Kruskal-Wallis, quando considerado apenas o tampão apical feito com o MTA-Angelus ${ }^{\circledR}$ cinza............................. 
Tabela 11 Comparação, pelo teste de Dunn, entre as técnicas obturadoras realizadas, para se determinar o nível de significância entre elas, considerando-se o MTA-Angelus ${ }^{\circledR}$ cinza........................................

Tabela 12 Avaliação da infiltração de Rodamina B a 0,2\% pelo teste nãoparamétrico de Kruskal-Wallis, quando considerado apenas o tampão apical feito com o $\mathrm{CPM}^{\circledR}$.....

Tabela 13 Comparação, pelo teste de Dunn, entre as técnicas obturadoras realizadas, para se determinar o nível de significância entre elas, considerando-se o $\mathrm{CPM}^{\circledR}$.

Tabela 14 Avaliação da infiltração de Rodamina B a 0,2\% pelo teste nãoparamétrico de Kruskal-Wallis, quando considerado apenas o tampão apical feito com o MBPc.

Tabela 15 Comparação, pelo teste de Dunn, entre as técnicas obturadoras realizadas, para se determinar o nível de significância entre elas, considerando-se o MBPc

Tabela 16 Avaliação da adaptação marginal, pelo teste não-paramétrico de Kruskal-Wallis, quando considerada apenas a técnica da condensação lateral

Tabela 17 Comparação, pelo teste de Dunn, entre os cimentos usados como tampão apical, para se determinar o nível de significância entre eles, considerando-se a técnica de condensação lateral.

Tabela 18 Avaliação da adaptação marginal, pelo teste não-paramétrico de Kruskal-Wallis, quando considerada apenas a técnica híbrida de Tagger.....

Tabela 19 Comparação, pelo teste de Dunn, entre os cimentos usados como tampão apical, para se determinar o nível de significância entre eles, considerando-se a técnica híbrida de Tagger.

Tabela 20 Avaliação da adaptação marginal, pelo teste não-paramétrico de Kruskal-Wallis, quando considerada apenas a técnica de injeção de guta-percha.

Tabela 21 Comparação, pelo teste de Dunn, entre os cimentos usados como tampão apical, para se determinar o nível de significância entre eles considerando-se a técnica de injeção de guta-percha. 
Tabela 22 Avaliação da adaptação marginal, pelo teste não-paramétrico de Kruskal-Wallis, quando considerado apenas o cimento MTA-

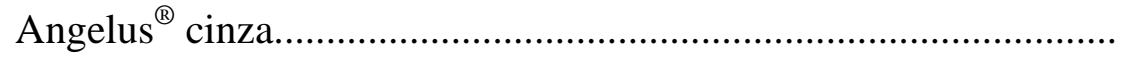

Tabela 23 Comparação, pelo teste de Dunn, entre as técnicas obturadoras utilizadas, para se determinar o nível de significância entre elas de acordo com o cimento MTA-Angelus ${ }^{\circledR}$ cinza..................................

Tabela 24 Avaliação da adaptação marginal, pelo teste não-paramétrico de Kruskal-Wallis, quando considerado apenas o cimento $\mathrm{CPM}^{\circledR}$...

Tabela 25 Comparação, pelo teste de Dunn, entre as técnicas obturadoras utilizadas, para se determinar o nível de significância entre elas, de acordo com o cimento $\mathrm{CPM}^{\circledR}$

Tabela 26 Avaliação da adaptação marginal, pelo teste não-paramétrico de Kruskal-Wallis, quando considerado apenas o cimento MBPc.......

Tabela 27 Comparação, pelo teste de Dunn, entre as técnicas obturadoras utilizadas, para se determinar o nível de significância entre elas, de acordo com cimento MBPc 


\section{LISTA DE SÍMBOLOS E ABREVIATURAS}

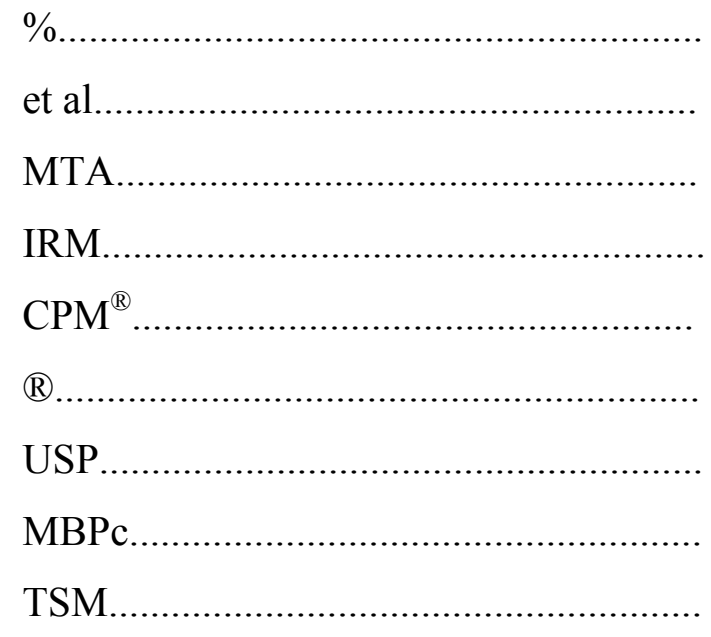

EBA

$\mathrm{Ph}$.

$\mathrm{MPa}$

$\mathrm{X}$

$\mu \mathrm{g}$.

TGF- $\beta$

IGF-1

PDGF

FDA

EUA

BHI

$\mathrm{mm}$

EDTA

M.E.V

EWT

${ }^{\circ} \mathrm{C}$.

UNESP

FOB.

ADA

ASTM

MBP

ISO. por cento

E colaboradores

Mineral Trioxide Aggregate

Intermediate Restorative Material

Cimento Portland Modificado

Marca registrada

Universidade de São Paulo

Moraes e Berbert Pasta (cirurgia)

Tanden Scanning Reflected light microscope

Ethoxybenzoic Acid

Potencial hidrogeniônico

Megapascal

Vezes

Micrograma

Transforming Growth Factor beta

Insulin Like Growth Factor 1

Platelet Derived Growth Factor

Food and Drug Administration

Estados Unidos da América

Brain and Heart Infusion

Milímetros

Ethylenodiaminic Tetracethic Acid

Microscópio eletrônico de varredura

Extended Working Time

graus Celsius

Universidade Estadual Paulista

Faculdade de Odontologia de Bauru

American Dental Association

American Society for Tests and Materials

Moraes e Berbert Pasta

International Standards Organization 


\begin{tabular}{|c|c|}
\hline 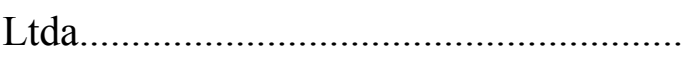 & Limitada \\
\hline ............... & Mililitro \\
\hline $\mathrm{L} \& \mathrm{C}$. & Lopes \& Costa \\
\hline NS... & Não significante \\
\hline S.. & Significante \\
\hline$+\ldots \ldots \ldots \ldots \ldots$ & Mais \\
\hline$<$.. & Menor \\
\hline $\mathrm{kV} \ldots$ & Quilovolts \\
\hline g... & Grama \\
\hline BMP-2... & Bone morphogenetic protein - 2 \\
\hline 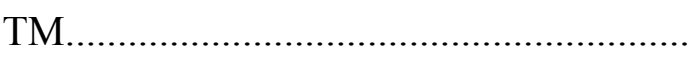 & Trade Mark \\
\hline
\end{tabular}




\section{RESUMO}

Foram analisadas a capacidade seladora e a adaptação marginal de tampões apicais confeccionados com diferentes materiais, sob a influência de três técnicas de obturação de canais radiculares. Foram utilizados cento e vinte dentes permanentes de humanos, unirradiculados e portadores de um canal, superiores ou inferiores, com raízes íntegras e ápices completamente formados. Após a abertura coronária, foi realizado o preparo dos canais radiculares pela técnica coroa-ápice, com brocas de Gates Glidden em ordem numérica decrescente, partindo-se da broca número 5 até a de número 1 , sendo que esta sempre ultrapassou o forame apical em $1 \mathrm{~mm}$. Após esse procedimento, os canais foram dilatados, ainda, com limas do tipo K, iniciando-se com a de número 50 até a de número 90, padronizando-se, assim, o diâmetro do forame. Durante a instrumentação, todas as limas ultrapassaram o forame apical em 1mm. Após esse procedimento, realizou-se a impermeabilização da superfície externa das raízes, com uma camada de Araldite e duas de esmalte para unhas. Na seqüência, os dentes foram divididos em 4 grupos de 30 espécimes cada, de acordo com os materiais utilizados na confecção dos tampões apicais, com 5mm de espessura: Grupo 1 - pasta L \& C, Grupo 2 - cimento MTA-Angelus ${ }^{\circledR}$ cinza, Grupo 3 - cimento CPM $^{\circledR}$ e Grupo 4 - cimento MBPc. A seguir, cada grupo foi dividido em três subgrupos, com 10 dentes cada, de acordo com a técnica obturadora utilizada: condensação lateral, híbrida de Tagger e sistema Ultrafil. Realizadas as obturações, os 10 dentes de cada subgrupo, devidamente identificados, foram imersos em solução corante de Rodamina B a 0,2\%, pH 7,0 e levados à estufa a $37^{\circ} \mathrm{C}$, onde permaneceram por 48 horas. Após a lavagem dos dentes e a retirada da impermeabilização, os mesmos foram desgastados longitudinalmente, na face mesial ou na distal, utilizando-se discos de carburundum, de modo a expor o tampão apical e a obturação. A análise da infiltração marginal foi feita utilizando-se fotografias digitalizadas, com o auxílio do software Image Tool 3.0. Como medida de infiltração, considerou-se o traço de maior extensão do corante, na interface tampão apical-parede dentinária, desde a porção mais apical do material até a sua porção mais cervical. Para a realização do teste de adaptação marginal às paredes dentinárias dos materiais utilizados como tampão apical, foram utilizados os mesmos dentes submetidos ao teste de infiltração de Rodamina B a 0,2\%, com exceção dos dentes do grupo 1 (pasta

L \& C). Assim, os 90 espécimes dos grupos 2, 3 e 4 foram seccionados 
transversalmente a $7 \mathrm{~mm}$ do ápice. Esses segmentos foram metalizados e levados ao microscópio eletrônico de varredura (M.E.V.), obtendo-se fotomicrografias com aumentos de 35X e 150X. Para a análise da adaptação marginal dos cimentos testados, as fotomicrografias com aumento de 35X foram levadas ao software Image Tool 3.0 e a mensuração da desadaptação foi feita de forma linear, medindo-se, em micrometros, a extensão da mesma. Os resultados obtidos, tanto da análise da infiltração como da adaptação marginal, foram tabulados e submetidos aos testes estatísticos de KruskalWallis e de Dunn. Os resultados mostraram que o cimento MBPc apresentou os menores índices de infiltração de Rodamina B a 0,2\%, com diferença estatística significante para os demais materiais; o cimento $\mathrm{CPM}^{\circledR}$ apresentou os melhores resultados quando avaliada a adaptação às paredes do canal radicular, porém sem significância estatística; as três técnicas obturadoras utilizadas não tiveram influência sobre a capacidade seladora e nem na adaptação dos tampões apicais.

Palavras-chave: Capacidade seladora. Adaptação marginal. Tampão apical. 


\section{1 - INTRODUÇÃO}




\section{INTRODUÇÃO}

A obturação de canais de dentes com necrose pulpar e reabsorção apical, assim como a de dentes com rizogênese incompleta e, também, de dentes que foram sobreinstrumentados durante o tratamento endodôntico, é uma das grandes dificuldades enfrentadas pelo profissional. Isto ocorre porque, nesses casos, a confecção de um batente apical, muitas vezes, não é conseguida, fazendo com que o risco de extravasamento do material obturador seja maior, o que serviria para manter uma irritação tecidual, dificultando, ou mesmo, impedindo o processo de reparo.

Assim, com o intuito de manter o material obturador confinado no interior do canal radicular, sem que ocorra o extravasavamento para a região periapical, tem-se buscado materiais que tenham a capacidade de induzir a formação de uma barreira de tecido mineralizado, no caso de dentes com rizogênese incompleta, ou que possam servir de anteparo ao material obturador, quando da realização da obturação, e sejam resistentes à infiltração e à compressão, além de serem biocompatíveis.

Em 1920, o hidróxido de cálcio foi introduzido na Odontologia por Herman (LEONARDO; SILVA ${ }^{59}$, 1998). No entanto, segundo WHITERSPOON; HAM ${ }^{116}$, (2001), Granath, em 1959, foi o primeiro a descrever o uso do hidróxido de cálcio para induzir o fechamento apical de dentes com rizogênese incompleta. Desde então, o hidróxido de cálcio, em combinação com a água destilada, solução salina estéril, solução anestésica, paramonoclorofenol canforado, ou base de metilcelulose, vem sendo utilizado como indutor de barreira de tecido mineralizado em dentes, tanto com polpas vivas ou necrosadas, e, também, com rizogênese incompleta (SHEEHY; ROBERTS ${ }^{84}$, 1997).

Contudo, WEISENSEEL; LAMAR HICKS; PELLEU ${ }^{115}$ (1987) afirmaram que, mesmo o hidróxido de cálcio tendo a capacidade de estimular a formação de uma barreira apical, os procedimentos de apicificação apresentam alguns inconvenientes, como a necessidade de várias sessões de atendimento ao paciente, pois, para a formação da barreira necessita-se de um período relativamente longo, bem como, o fato de que as constantes trocas desse medicamento, no interior do canal radicular, poderiam interromper a formação daquela barreira. Tais considerações também foram feitas por SHEEHY; ROBERTS ${ }^{84}$, que em 1997, por meio de uma revisão de literatura, verificaram ser o hidróxido de cálcio o material de escolha para a indução de uma 
barreira apical em dentes permanentes, mesmo com necrose pulpar e rizogênese incompleta, e que o índice de sucesso variava entre 74\% e 100\%. Além disso, os autores relataram que o período para a formação dessa barreira poderia variar entre 5 e 20 meses.

Já em 2005, FELIPPE et al. ${ }^{35}$ verificaram, após um estudo em dentes de cães, que a troca da pasta de hidróxido de cálcio, a cada trinta dias, em dentes com rizogênese incompleta, reduziu significativamente a intensidade do processo inflamatório. Contudo, os resultados mostraram que essa troca reduziu a ocorrência da apicificação de forma significativa.

Assim, para suprir tais inconvenientes, em especial a redução do número de sessões para o término do tratamento endodôntico, tem-se utilizado a manobra do tampão apical. De acordo com SIQUEIRA JR.; LOPES; ELIAS ${ }^{93}$, (2004), o uso do tampão apical tem dois objetivos, o mecânico e o biológico. O objetivo mecânico seria o de atuar como um obstáculo ao extravasamento da guta-percha e do cimento utilizados na obturação do canal radicular, enquanto o biológico seria o de favorecer a reparação por um tecido mineralizado junto à área crítica apical.

Vários materiais têm sido utilizados para a confecção de tampão apical. Além do hidróxido de cálcio, utilizado tanto em pó (HOLLAND ${ }^{48}$, 1984, WEISENSEEL; LAMAR HICKS; PELLEU ${ }^{115}$, 1987) quanto em pasta (LOPES; COSTA FILHO ${ }^{63}$, 1988), alguns trabalhos relatam o uso do fosfato tricálcico (COVIELLO; BRILLIANT ${ }^{28}$, 1979; HARBERT ${ }^{45}$, 1991; HARBERT ${ }^{46}$, 1996), da dentina liofilizada (ROSSMEISL et al. $^{80}$, 1982), do osso cortical liofilizado (ROSSMEISL et al. ${ }^{81}$, 1982), da hidroxiapatita (WYLIE BRANDELL et al. ${ }^{120}$, 1986) e, com maior freqüência, das raspas de dentina (HOLLAND et al. ${ }^{49}$, 1980; ELDEEB; THUC-QUYEN; JENSEN ${ }^{31}$, 1983; HOLLAND ${ }^{46}$, 1984; PITTS; JONES; OSWALD ${ }^{78}$, 1984; YEE et al. ${ }^{125}$, 1984; BRADY; HIMEL; WEIR ${ }^{19}$, 1984; JACOBSEN; BERY; BEGOLE $\left.^{52}, 1984\right)$.

HOLLAND $^{48}$, em 1984, relatou que não há diferença histológica entre tampões apicais feitos com raspas de dentina e com hidróxido de cálcio em pó. Isto poderia servir de motivo para se optar pela confecção do tampão apical com raspas de dentina. Todavia, o autor apresentou duas possíveis desvantagens em relação ao uso deste material. A primeira desvantagem está ligada à necessidade de que as raspas de dentina estejam estéreis. Em dentes vitais isto não é problema, mas em dentes com necrose pulpar a confecção de tampões apicais com raspas, ainda infectadas, poderia 
acontecer, o que induziria uma resposta inflamatória crônica. Já, a segunda desvantagem está relacionada ao fato de que, em estudos in vitro, as raspas de dentina não produziram um bom selamento apical, possivelmente, devido ao seu tamanho ser considerado grande e sua forma irregular.

Assim, segundo SIQUEIRA JR; LOPES; ELIAS ${ }^{93}$, (2004), os materiais capazes de cumprir os objetivos mecânico e biológico de um tampão apical seriam o hidróxido de cálcio e o agregado de trióxido mineral (MTA).

Em 1984, os professores Hélio Pereira Lopes e Arlindo dos Santos Costa Filho publicaram um trabalho que procurou analisar as dificuldades existentes em relação ao tratamento endodôntico de dentes permanentes com rizogênese incompleta e necrose pulpar, em relação à técnica, à substância utilizada e ao tipo de reparação apical após a intervenção. Neste mesmo trabalho, é descrita a composição de uma pasta, à base de hidróxido de cálcio, utilizada pelos referidos professores na obturação temporária dos dentes com rizogênese incompleta e necrose pulpar. Tal pasta foi idealizada baseandose em estudos do professor Mário Roberto Leonardo, e utilizava as mesmas proporções por ele propostas em sua pasta, diferindo, apenas, quanto ao radiopacificador (carbonato de bismuto em detrimento ao sulfato de bário) e ao veículo utilizado (óleo de oliva ao invés do polietilenoglicol 400) (LOPES; COSTA FILHO ${ }^{62}$, 1984). Em 1988, LOPES; COSTA FILHO ${ }^{63}$, publicaram um estudo demonstrando a eficiência da pasta L \& C quando utilizada como tampão apical.

O agregado de trióxido mineral (MTA) foi desenvolvido por Mahmoud Torabinejad no início dos anos 90, na Universidade de Loma Linda - Califórnia, Estados Unidos da América, com o objetivo de selar as comunicações entre o interior e o exterior do dente. (BERNABÉ; HOLLAND ${ }^{16}$, 2003). O primeiro trabalho científico que empregou o MTA foi publicado em 1993 por LEE, MONSEF; TORABINEJAD ${ }^{57}$, no qual ele foi utilizado in vitro, em casos de perfuração radicular lateral de molares humanos, testando-se o selamento, após imersão em azul de metileno. Os resultados mostraram superioridade do MTA em relação ao IRM e ao amálgama de prata. Ainda, segundo os autores, o MTA foi originariamente indicado como material retrobturador, em cirurgias parendodônticas, e em casos de perfurações intra-radiculares e de furca.

Em 1996, TITTLE et al. ${ }^{104}$ foram os primeiros a realizar um estudo utilizando o MTA como barreira apical, obtendo bons resultados e, em 1999, TORABINEJAD; CHIVIAN ${ }^{105}$ ampliaram as indicações clínicas desse material, incluindo, entre elas, o seu uso como tampão apical, devido às suas propriedades físico- 
químicas e biológicas. Assim, vários estudos foram feitos utilizando-se o MTA como tampão apical (KWAK; PARK; OH ${ }^{55}$, 2000; HACHMEISTER et al. ${ }^{43}$, 2002; AMINOSHARIAE; HARTWELL; $\mathrm{MOON}^{6}$, 2003; VALOIS; COSTA JR. ${ }^{111}$, 2004; MATT et al. $^{71}$, 2004; LAWLEY et al. ${ }^{56}$, 2004; AL-KAHTANI et al. ${ }^{5}$ 2005; CONEGLIAN; BRAMANTE; OROSCO ${ }^{27}$, 2005; EL-MELIGY; AVERY ${ }^{32}$, 2006; XU et al. ${ }^{123}$, 2006; STUART; SCHWARTZ; BEESON ${ }^{100}$, 2006; YEUNG; LIEWEHR; MOON $^{126}$, 2006), bem como vários relatos de casos clínicos onde ele foi utilizado (GÓMEZ $^{41}$, 2000; LEVENSTEIN ${ }^{60}$, 2002; GIULIANI et al. $^{40}$, 2002; LINSUWANONT $^{61}$, 2003; MAROTO et al. ${ }^{69}$, 2003; LYNN; EINBENDER ${ }^{65}$, 2003; BRAMANTE; BORTOLUZZI; BROON ${ }^{20}$, 2004; HAYASHI; SHIMIZU; EBISU ${ }^{47}$, 2004; XU et al. ${ }^{122}$, 2006).

Em 2003, foi lançado na Argentina o $\mathrm{CPM}^{\circledR}$ (Cimento Portland Modificado), que também é um tipo de agregado de trióxido mineral, cujas indicações clínicas seriam as mesmas do MTA $\left(\right.$ CASTRO $\left.^{24}, 2003\right)$.

A partir de uma linha de pesquisa que teve início em 1984, com o Prof. Dr. Ivaldo Gomes de Moraes e com o Prof. Dr. Alceu Berbert, foi desenvolvido na disciplina de Endodontia da Faculdade de Odontologia de Bauru - USP um cimento endodôntico cirúrgico, o MBPc, à base de resina epóxica e contendo em sua fórmula o hidróxido de cálcio. Este cimento estaria indicado para ser utilizado em obturações retrógradas $\left(\mathrm{PAVAN}^{77}, 1999\right)$ e perfurações radiculares (SILVA NETO; MORAES ${ }^{88}$, 2003).

Tendo em vista que o tratamento de dentes com rizogênese incompleta e necrose pulpar ou com ápices arrombados, quando realizado com o hidróxido de cálcio, demanda uma longa espera, pela necessidade de várias trocas, apresentando dificuldades para que possa ser finalizado, ou mesmo, diante da possibilidade de que ocorra extravasamento de materiais obturadores durante a obturação dos canais radiculares, torna-se interessante avaliar a possibilidade da utilização de cimentos como o MTAAngelus $^{\circledR}$ cinza, o $\mathrm{CPM}^{\circledR}$ e o MBPc, como tampões apicais, o que possibilitaria a diminuição no tempo de tratamento dos casos acima citados, sem que ocorresse um decréscimo no índice de sucesso.

Desta forma, no capítulo seguinte será feita a revisão da literatura, cujos resumos serão apresentados com o intuito de servirem de subsídio para a viabilidade do trabalho. 


\section{2 - REVISÃO DE LITERATURA}




\section{REVISÃO DE LITERATURA}

A revisão de literatura será apresenta em quatro partes, referentes à pasta e aos cimentos utilizados.

\subsection{Pasta L \& C (Lopes \& Costa)}

LOPES; COSTA FILHO ${ }^{62}$, em 1984, publicaram um estudo descrevendo a composição de uma pasta, sendo o pó composto por $2 \mathrm{~g}$ de hidróxido de cálcio, $1 \mathrm{~g}$ de bicarbonato de bismuto e $0,05 \mathrm{~g}$ de colofônia, tendo o óleo de oliva como veículo, e também a técnica de utilização da mesma, apresentando, inclusive, quatro casos clínicos em que foram realizados os tratamentos endodônticos de dentes com rizogênese incompleta e com necrose pulpar. Nos quatro casos apresentados, a pasta de hidróxido de cálcio foi utilizada com a finalidade de promover a apicificação e, após a obtenção da mesma, os canais foram obturados.

Em 1988, LOPES; COSTA FILHO ${ }^{63}$, utilizaram a pasta L \& C como tampão apical em dentes despolpados e com lesões periapicais. Foram incluídos 50 dentes unirradiculados, apresentando completo desenvolvimento radicular, porém, com perda óssea periapical, e divididos em 2 grupos: Grupo I - 10 dentes, e Grupo II - 40 dentes. No grupo I, os dentes tiveram os canais obturados temporariamente com a pasta L \& C e foram realizados exames clínico-radiográficos aos 7, 30, 90, 180 e 365 dias. Após o último exame, a pasta foi retirada dos canais e fez-se a obturação com cones de guta-percha e cimento, pela técnica de condensação lateral. No grupo II, os 40 canais também foram totalmente preenchidos com a pasta L \& C. Contudo, após 7 dias, retirou-se, parcialmente, a pasta do interior do canal, deixando-se um tampão de 3 a $4 \mathrm{~mm}$, completando-se a obturação com cones de guta-percha e cimento, pela técnica de condensação lateral. Os resultados mostraram que no grupo I, após 365 dias, a reparação ocorreu em todos os casos, sendo total em 8 e parcial em 2 casos. Já, no grupo II, após 365 dias, 4 pacientes não retornaram. Em 3 dentes observou-se aumento da área radiolúcida e sensação dolorosa à palpação, a nível apical. A reparação foi total em 25 casos e parcial nos 8 restantes.

Em 1997, BITTENCOURT; MALLMANN; REZENDE ${ }^{17}$ avaliaram, em dentes de cães, o comportamento da polpa após a pulpotomia e recobrimento com pastas à base de hidróxido de cálcio, manipuladas com diferentes veículos e o óxido de zinco e 
eugenol. Foram utilizados quatro cães da raça Beagle, e em cada animal foram executadas 20 pulpotomias. Quatro grupos foram feitos, sendo, grupo I - Hemiarco superior direito: com pasta de hidróxido de cálcio P.A. e propilenoglicol; grupo II Hemiarco superior esquerdo: com cimento de óxido de zinco e eugenol; grupo III Hemiarco inferior direito: com pasta L \& C e grupo IV - Hemiarco inferior esquerdo: com pasta Calen. Após 90 dias os animais foram sacrificados, os maxilares removidos e processados para o exame histológico. Os grupos I e IV apresentaram o maior número de barreiras mineralizadas consideradas completas. Contudo, no grupo III, apesar de haver uma incidência menor de barreiras completas em relação aos grupos I e IV, as barreiras formadas eram bem mais espessas e definidas. Estas evidências permitiram afirmar que a utilização do hidróxido de cálcio, manipulado com veículo oleoso, parece manter a alcalinidade da área por um tempo maior, determinando uma estimulação continuada à deposição de tecido duro. No grupo II, nenhuma barreira completa foi formada. No entanto, na maioria dos casos, a polpa manteve-se com vitalidade.

MACHADO ${ }^{66}$, 2000, apud SIQUEIRA JR; RÔÇAS; LOPES ${ }^{94}, 2004$, avaliou a infiltração de corante (azul de metileno diluído em soro fetal bovino), após a obturação de canais radiculares pela técnica da compressão hidráulica. Foram utilizados três grupos, divididos de acordo com o material empregado na obturação, sendo grupo I - pasta L \& C; grupo II - Sealer 26, e grupo III - EndoFill. Os resultados mostraram que o grupo I apresentou a menor infiltração em relação aos demais materiais.

BERGER; LIMA; POSSAGNO ${ }^{15}$, em 2001, avaliaram a eficiência do hidróxido de cálcio com veículo oleoso no fechamento apical de dentes com rizogênese incompleta e necrose pulpar. $\mathrm{O}$ estudo foi realizado em doze pacientes, com idade entre oito e onze anos. Na primeira sessão, todos os dentes tiveram os canais instrumentados e, após a secagem dos mesmos, foi colocada uma pasta de hidróxido de cálcio com soro fisiológico como medicação intracanal. Na segunda sessão, realizada entre sete e dez dias após a primeira, a pasta de hidróxido de cálcio com soro fisiológico foi substituída pela pasta L \& C (hidróxido de cálcio com óleo de oliva), permanecendo nos canais por quatro meses. Após esse período, todos os canais foram obturados com guta-percha e cimento, pela técnica da condensação lateral. Segundo os autores, na maioria dos casos, o que permitiu o travamento dos cones de guta-percha foi a pasta, que permaneceu rígida no terço apical, possibilitando o uso da mesma como tampão apical.

FERREIRA $^{36}$, 2001, apud SIQUEIRA JR; RÔÇAS; LOPES ${ }^{92}$, 2004, avaliou a capacidade da pasta $\mathrm{L} \& \mathrm{C}$ e do cimento AH Plus, associados a cones de guta- 
percha na obturação de canais radiculares, em prevenir a infiltração de microrganismos da saliva. Após 67 dias, foi verificado que a infiltração ocorreu em 45\% dos espécimes obturados com a pasta L \& C e em 65\% dos obturados com AH Plus.

FARIA $^{33}$, 2003, apud SIQUEIRA JR; RÔÇAS; LOPES ${ }^{94}$, 2004, também comparou o nível da infiltração apical de azul de metileno dissolvido em soro fetal bovino, porém, utilizando a pasta L \& C, o MTA e o óxido de zinco e eugenol em retrobturações. Os resultados mostraram que, tanto a pasta L \& C como o MTA foram estatisticamente superiores ao óxido de zinco e eugenol.

\subsection{Cimento MTA (Agregado de Trióxido Mineral)}

LEE; MONSEF; TORABINEJAD ${ }^{57}$, em 1993, publicaram o primeiro trabalho científico que empregava esse novo material, o agregado de trióxido mineral (MTA). Nesse trabalho, os autores testaram, in vitro, a capacidade de selamento do MTA em casos de perfuração radicular lateral de molares humanos quando comparado ao IRM e ao amálgama de prata. Os resultados, após a imersão dos espécimes em azul de metileno por 48 horas, demonstraram que o grupo do MTA apresentou os menores índices de infiltração, sendo estatisticamente superior aos demais materiais. Ainda, segundo os autores, o MTA foi originariamente indicado como material retrobturador em cirurgias parendodônticas e em casos de perfurações intra-radiculares e de furca.

Ainda, em 1993, TORABINEJAD; WATSON; PITT FORD ${ }^{110}$ realizaram um estudo, in vitro, utilizando o corante fluorescente rodamina B para avaliar a capacidade de selamento do amálgama, do Super-EBA e do MTA, quando utilizados como materiais retrobturadores. Trinta dentes humanos unirradiculados tiveram as coroas removidas, os canais instrumentados e obturados com guta-percha e cimento endodôntico. Após a impermeabilização da superfície externa das raízes, as mesmas foram seccionadas apicalmente, no sentido transversal e cavidades com $3 \mathrm{~mm}$ de profundidade foram preparadas. As raízes foram divididas em três grupos aleatórios e as cavidades apicais preenchidas com os materiais experimentais. Todas as raízes foram, então, colocadas em uma solução corante de rodamina B por 24 horas. Após esse período, foram seccionadas longitudinalmente, e a extensão da infiltração do corante mensurada por meio de um microscópio TSM ("Tanden Scanning Reflected light microscope"). A análise estatística dos resultados mostrou que a infiltração nas 
obturações com MTA foi significantemente menor que nas obturações com amálgama ou Super-EBA.

TORABINEJAD et al. ${ }^{106}$, em 1994, analisaram a quantidade de infiltração de corante, na presença e na ausência de sangue, em cavidades apicais preenchidas com MTA, IRM, Super-EBA e amálgama. Noventa dentes humanos unirradiculados, extraídos, tiveram as coroas removidas, os canais radiculares instrumentados e obturados. As superfícies radiculares foram impermeabilizadas com duas camadas de esmalte para unhas, exceto os $2 \mathrm{~mm}$ apicais, que foram seccionados. Uma cavidade apical estandardizada foi preparada em cada raiz. Oitenta raízes foram divididas aleatoriamente em quatro grupos experimentais. Para cada grupo, metade do número de cavidades apicais foi seca previamente à inserção do material e a outra, preenchida após ter sido contaminada com sangue. Cinco cavidades apicais foram preenchidas com gutapercha sem cimento (controle positivo) e outras cinco com cera em bastão (controle negativo). Todas as noventa raízes foram imediatamente imersas em azul de metileno a $1 \%$, por 72 horas. Foram retiradas do corante, cortadas ao meio no sentido longitudinal e, então, a infiltração linear do corante foi mensurada e analisada estatisticamente. A presença ou ausência de sangue não apresentou efeito significante na quantidade da infiltração do corante, porém, houve diferença significante de infiltração entre os materiais retrobturadores. Com MTA a infiltração foi significantemente menor que a dos demais materiais testados, com ou sem a contaminação sangüínea das cavidades apicais.

Em 1995, TORABINEJAD et al. ${ }^{107}$ determinaram a composição química, o pH e a radiopacidade do MTA, além de compararem-no ao amálgama, ao Super-EBA e ao IRM, em relação ao tempo de presa, a resistência à compressão e à solubilidade. Os resultados mostraram que as principais moléculas presentes no MTA são os íons cálcio e fósforo. $\mathrm{O}$ pH inicial foi de 10,2, aumentando para 12,5, três horas após a sua mistura. O MTA mostrou-se mais radiopaco que o Super-EBA e o IRM. Em relação ao tempo de presa, o amálgama apresentou o menor tempo (4 minutos) e o MTA o maior (duas horas e quarenta e cinco minutos). Em um período de 24 horas o MTA apresentou a menor resistência à compressão $(40 \mathrm{MPa})$ entre os materiais, aumentando para $67 \mathrm{MPa}$ após 21 dias. Com exceção do IRM, os demais materiais não mostraram qualquer solubilidade sob as condições do estudo. 
Ainda, em 1995, TORABINEJAD et al. ${ }^{108}$ realizaram um estudo para determinar o tempo necessário para o Staphylococcus epidermidis ultrapassar obturações retrógradas feitas com amálgama, Super-EBA, IRM e agregado de trióxido mineral (MTA). Cinqüenta e seis dentes unirradiculados, extraídos de humanos tiveram os canais instrumentados utilizando-se a técnica clássica. Após a secção das raízes, 48 retrocavidades, com $3 \mathrm{~mm}$ de profundidade, foram obturadas com os materiais acima citados. Quatro retrocavidades foram obturadas com guta-percha termoplastificada sem cimento endodôntico (controle positivo) e outras quatro com cera quente e coberta com duas camadas de esmalte para unhas (controle negativo). A superfície radicular externa de todos os dentes foi impermeabilizada com esmalte para unhas. Os ápices dentais foram imersos em um frasco contendo meio de cultura estéril e os canais radiculares foram preenchidos com Staphylococcus epidermidis. O monitoramento da passagem bacteriana via retrobturação foi realizado diariamente. A maioria dos espécimes cujas retrobturações foram realizadas com amálgama, Super-EBA ou IRM apresentaram infiltração em um período que variou dos 6 aos 57 dias. Já, dos espécimes que foram retrobturados com o MTA, a maioria não apresentou infiltração bacteriana após 90 dias.

Em outro estudo realizado em 1995, TORABINEJAD et al. ${ }^{109}$ analisaram a adaptação marginal do agregado de trióxido mineral (MTA) quando utilizado como material retrobturador, comparando-o aos materiais comumente usados em tal situação, sob microscopia eletrônica de varredura. Oitenta e oito dentes humanos, unirradiculados, extraídos, tiveram seus canais instrumentados e obturados com gutapercha e cimento endodôntico. Em seguida, foram apicectomizados e as retrocavidades preparadas e preenchidas com MTA, IRM, Super-EBA ou amálgama. Quarenta raízes foram seccionadas longitudinalmente em duas metades, e réplicas de resina das raízes remanescentes, não seccionadas, também foram preparadas. Após montar as secções longitudinais e as réplicas de resina das raízes apicectomizadas em bases de alumínio, a distância entre os materiais retrobturadores testados e a superfície dentinária (desadaptação) foi mensurada em quatro pontos por meio de um microscópio eletrônico de varredura com aumentos de $30 \mathrm{X}$ e 100X. A avaliação dos exemplares originais mostrou numerosos artefatos nas secções longitudinais, o que não ocorreu nas réplicas de resina. A análise estatística dos dados, comparando os espaços abertos entre os materiais retrobturadores e a superfície dentinária (desadaptação), mostrou que o MTA apresentou melhor adaptação marginal quando comparado aos demais. 
ABEDI; INGLE², também em 1995, relataram, por meio de uma revisão de literatura, algumas propriedades físicas do MTA, assim como a sua biocompatibilidade e o seu uso em experimentos com animais. Afirmaram que o MTA possui muitas vantagens em relação aos materiais comumente usados (amálgama e IRM), em especial a sua propriedade hidrofílica, que facilita o uso em perfurações radiculares.

Por meio do sistema de transporte de fluidos, BATES; CARNES; DEL RIO $^{12}$, em 1996, avaliaram o MTA, o Super-EBA e o amálgama quando utilizados como materiais retrobturadores quanto à microinfiltração. Foram utilizados 72 dentes humanos extraídos, os quais foram apicectomizados e retrocavidades foram preparadas e retrobturadas com os materiais testados. Os espécimes foram colocados em solução salina de fosfato, tamponada, em alta pressão. A microinfiltração foi avaliada nos seguintes períodos experimentais: 24 horas, 72 horas, duas, quatro, oito e doze semanas. A microinfiltração nos grupos do MTA e do Super-EBA foi estatisticamente menor que no grupo do amálgama nos períodos de 24 horas, 72 horas e duas semanas. Nos demais períodos não houve diferença estatisticamente significante entre os três materiais testados.

TITTLE et al. ${ }^{104}$, em 1996, realizaram um estudo utilizando o MTA como barreira apical. O estudo comparou a capacidade de três combinações diferentes de fatores de crescimento ósseo à do hidróxido de cálcio, em estimular o selamento apical, assim como a efetividade do agregado de trióxido mineral (MTA) como barreira apical. Cinqüenta e seis raízes de segundos e quartos pré-molares inferiores de cães foram usadas. Lesões periapicais foram induzidas durante um período de quatro semanas. Os canais foram, então, instrumentados, irrigados com hipoclorito de sódio a 5,25\% e preenchidos com hidróxido de cálcio, que permaneceu nos canais por uma semana. Após a remoção desse material, cada canal recebeu um dos sete diferentes tratamentos possíveis. Os fatores de crescimento foram colocados em um carregador de carboximetilcelulose e deixados nos canais radiculares da maneira como se segue: grupo I: $0,5 \mu \mathrm{g}$ de TGF- $\beta$ e $25 \mu \mathrm{g}$ de IGF-1; grupo II: $5 \mu \mathrm{g}$ de TGF- $\beta$ e $25 \mu \mathrm{g}$ de IGF-1; grupo III: $25 \mu \mathrm{g}$ de IGF-1 e $25 \mu \mathrm{g}$ de PDGF; grupo IV: recebeu apenas o carregador; grupo V: canais foram obturados com hidróxido de cálcio; grupo VI: canais foram obturados com MTA e grupo VII: não recebeu tratamento. Os animais foram sacrificados após nove semanas e, então, o grau de apicificação e o tamanho da lesão foram avaliados radiográfica e histologicamente. Os grupos I, IV, V e VI produziram 
maior quantidade de osteodentina que o grupo VII. Não houve diferença estatisticamente significante entre o tamanho das lesões, contudo, no grupo do MTA as mesmas eram menores, tanto histológica quanto radiograficamente.

SLUYK; MOON; HARTWELL ${ }^{95}$, em 1998, avaliaram as propriedades de endurecimento e as características de adesão do MTA, quando utilizado como material reparador de perfurações de furca. Trinta e dois molares humanos, superiores e inferiores, extraídos, tiveram as coroas seccionadas um pouco acima do assoalho da câmara pulpar, e as raízes removidas logo abaixo da região de furca. As porções remanescentes foram montadas em bases de resina acrílica e, então, foram perfuradas com brocas esféricas número 2 , perpendicularmente à cada secção da furca. A abertura foi ampliada com uma broca de Gates-Glidden número 5, criando-se uma perfuração com 1,4mm de diâmetro. Uma matriz de espuma de "Gelfoam" umedecida com solução salina foi colocada sob a perfuração para simular as condições clínicas. Os espécimes foram divididos aleatoriamente em quatro grupos. Todas as perfurações foram obturadas com o agregado de trióxido mineral (MTA) e, então, cobertas com mechas de algodão secas ou úmidas por 24 ou 72 horas. Para medir a força necessária para deslocar o material da perfuração foi utilizado o teste de Instron. Os resultados mostraram que o MTA resistiu ao deslocamento, após 72 horas, a um nível significativamente maior do que após 24 horas. A presença de umidade no local da perfuração durante a inserção foi vantajosa, auxiliando a adaptação do MTA às paredes da perfuração. Porém, não houve diferença significante na adesão do MTA quando a mecha de algodão, úmida ou seca, foi colocada no interior da câmara pulpar durante o período de endurecimento (tempo de presa).

No final de 1998, o MTA foi aprovado pela FDA (Food and Drug Administration) norte-americana e lançado comercialmente, em 1999, pela Dentisply Tulsa Dental, Oklahoma - EUA, com o nome de Pro Root MTA (BERNABÉ; HOLLAND $\left.^{16}, 2003\right)$.

WUCHERPFENNIG; GREEN ${ }^{119}$, em 1999, chamaram a atenção para o fato de que o MTA e o cimento Portland eram materiais muito semelhantes. Tal afirmação foi fundamentada em análises macro e microscópicas e por meio da difração de raios-X.

Em 1999, SHABAHANG et al. ${ }^{83}$ compararam a eficácia da proteína osteogênica 1 e do MTA com o hidróxido de cálcio na formação de tecido mineralizado em dentes de cães com rizogênese incompleta. Sessenta e quatro raízes de pré-molares 
foram utilizadas. Após a indução de lesões periapicais, os canais foram instrumentados, debridados e preenchidos com hidróxido de cálcio por uma semana. Após a remoção do hidróxido de cálcio, os canais foram divididos em quatro grupos, sendo três com os materiais testados (MTA, proteína osteogênica 1 e hidróxido de cálcio), e o grupo controle negativo (colágeno). Os cães foram sacrificados após 12 semanas, e o grau de formação de tecido mineralizado e o teor da inflamação foram avaliados histomorfologicamente. O MTA produziu uma formação de tecido mineralizado na região apical com uma consistência mais significativa que os outros materiais. A diferença na quantidade de tecido mineralizado produzido pelos três materiais testados não foi estatisticamente significante, verificando-se o mesmo para o grau de inflamação ante os três materiais.

ADAMO et al. $^{3}$, em 1999, avaliaram comparativamente a infiltração bacteriana em dentes humanos extraídos e que foram retrobturados com MTA, Super EBA, resina composta TPH mais adesivo dentinário Pro Bond e amálgama (com e sem aplicação de adesivo Pro Bond). Sessenta dentes unirradiculados de humanos foram divididos aleatoriamente em cinco grupos, um para cada material testado. Os dentes tiveram os canais instrumentados, sendo, posteriormente, apicectomizados e os materiais inseridos em retrocavidades de três milímetros de profundidade preparadas com ultra-som. Toda a superfície radicular externa foi impermeabilizada com esmalte para unhas, exceto o local preenchido com os materiais testados. As amostras foram esterilizadas em óxido de etileno. Cerca de três milímetros das raízes foram imersos em meio de cultura BHI com indicador fenol vermelho. $\mathrm{O}$ canal radicular de todos os dentes foi preenchido com uma suspensão de Streptococcus salivarius. O meio de cultura foi observado diariamente para verificação da mudança de cor indicativa de contaminação bacteriana. O período de observação foi de 12 semanas, e os autores concluíram que, sob as condições do estudo, não houve diferença estatisticamente significante no valor da infiltração entre os cinco grupos testados.

TORABINEJAD; CHIVIAN ${ }^{105}$, também em 1999, ampliaram as indicações clínicas do MTA. Os autores relataram que vários experimentos in vitro e in vivo haviam sido feitos para comparar a capacidade de selamento do MTA, principalmente com o amálgama, Super-EBA e IRM. A capacidade de selamento do MTA foi avaliada por estudos que utilizaram a infiltração de corantes e de bactérias, e o MTA mostrou-se superior ao amálgama e igual ou superior ao Super-EBA. Além disso, apresentaram as 
possíveis indicações clínicas do MTA, que seriam o capeamento pulpar, a pulpotomia, como tampão apical, como material preenchedor de perfurações, como material retrobturador e como barreira coronária prévia ao clareamento de dentes desvitalizados, descrevendo os procedimentos que deveriam ser realizados para a utilização do MTA em cada indicação clínica.

KWAK; PARK; $\mathrm{OH}^{55}$, já em 2000, realizaram um estudo com a intenção de determinar a ocasião oportuna de se realizar a obturação do canal com cimento e gutapercha quando o MTA fosse usado como tampão apical e, também, para determinar se a obturação afetaria o desempenho de um tampão apical de MTA mais delgado. Foram utilizados 42 dentes unirradiculados, os quais foram divididos em quatro grupos (A, B, C e D). Nos canais dos dentes do grupo A foi confeccionado um tampão de $2 \mathrm{~mm}$ e obturação imediata; nos do grupo B o tampão foi, também, de $2 \mathrm{~mm}$, porém a obturação foi realizada 24 horas mais tarde; nos do grupo C foi confeccionado um tampão de $4 \mathrm{~mm}$ e obturação imediata, e nos do grupo D foi utilizado um tampão de $4 \mathrm{~mm}$ e obturação 24 horas mais tarde. Os resultados mostraram que não houve diferença significante na penetração do corante entre os quatro grupos experimentais. Concluiu-se, então, que o tampão apical de MTA e a obturação com guta-percha e cimento podem ser feitos em uma única sessão, sem perda da capacidade de selamento. Ressaltaram que essa capacidade não é afetada com o uso de um tampão apical mais delgado, desde que o mesmo não seja deslocado, como aconteceu com oito dos vinte dentes dos grupos $\mathrm{A}$ e $\mathrm{B}$, cujos tampões possuíam $2 \mathrm{~mm}$ de espessura.

SHABAHANG; TORABINEJAD ${ }^{82}$, em 2000, foram os primeiros a relatarem, clinicamente, o uso do MTA para o tratamento de dentes com ápices incompletos. Apresentaram três casos clínicos, em dois dos quais o MTA foi utilizado como tampão apical. Os autores confeccionaram os tampões com cerca de $3 \mathrm{~mm}$ de espessura e a obturação da porção remanescente do canal radicular foi feita com gutapercha termoplastificada, utilizando o sistema Obtura II. No terceiro caso clínico relatado, o MTA foi usado como capeador pulpar, após pulpotomia, levando à complementação dos ápices dos dentes, após dois anos do tratamento.

GÓMEZ ${ }^{41}$, em 2000, relatou, por meio de dois casos clínicos, o uso do MTA como barreira apical em dentes com o ápice aberto. Em ambos os casos, primeiramente foram deixados curativos de hidróxido de cálcio nos canais radiculares, com o objetivo de descontaminá-los. Após a confecção do tampão apical de MTA, 
tendo cerca de $3 \mathrm{~mm}$ de espessura, os pacientes retornaram na sessão seguinte para a obturação das porções remanescentes dos canais radiculares com guta-percha termoplastificada, pelo sistema Obtura II, e cimento endodôntico.

WHITERSPOON; HAM ${ }^{116}$, em 2001, indicaram a utilização do MTA, em uma sessão, em substituição ao hidróxido de cálcio, como indutor de barreira de tecido mineralizado na região apical, em dentes com rizogênese incompleta. Para isso, os autores relataram a técnica de colocação do MTA no terço apical do canal radicular. Recomendaram a utilização de condensadores manuais para levar o material ao local desejado e, também, o uso do ultra-som para promover vibrações no condensador, o que, segundo eles, facilita o escoamento do MTA para o ápice, melhorando a sua adaptação. $\mathrm{Na}$ mesma sessão, a porção remanescente do canal radicular pode ser preenchida com material obturador, e a abertura coronária é selada com resina composta.

Em 2001, a empresa brasileira Angelus Soluções Odontológicas lançou no mercado o MTA desenvolvido no Brasil, que apresentava menor custo e era, aparentemente, semelhante ao Pro Root MTA (SILVA NETO et al. ${ }^{89}, 2003$; ROCHA ${ }^{79}$, 2003; ARAÚJO et al. ${ }^{10}$, 2004; MENEZES et al. ${ }^{72}, 2004$; SIQUEIRA et al. ${ }^{90}$, 2004).

Utilizando uma das várias maneiras de se analisar a infiltração marginal, TANG; TORABINEJAD; KETTERING ${ }^{102}$, em 2002, compararam, in vitro, a capacidade do MTA, do IRM, do Super-EBA e do amálgama em prevenir a infiltração de endotoxinas bacterianas, quando utilizados como materiais retrobturadores. Utilizaram 104 raízes extraídas, as quais, depois de terem os canais instrumentados, foram divididas em quatro grupos experimentais com 23 espécimes cada e três grupos controles com quatro espécimes cada. Foram preparadas retrocavidades com $3 \mathrm{~mm}$ de profundidade que, em seguida, foram preenchidas com os materiais experimentais. As raízes foram fixadas em tubos de microcentrífuga (eppendorfs), e dentro desses tubos foi colocada a endotoxina. O conjunto formado pelo tubo de microcentrífuga, pela raiz retrobturada e pela endotoxina foi fixado em um frasco de vidro contendo meio de cultura estéril. Os materiais foram avaliados nos períodos de uma, duas, seis e doze semanas. A cada período experimental, retirava-se uma alíquota do meio de cultura para a verificação da presença da endotoxina, o que indicaria a sua passagem pelo material retrobturador. Os resultados mostraram que o MTA foi melhor que o amálgama e o IRM em todos os períodos avaliados. Já, com relação ao Super-EBA, o MTA foi 
superior nos períodos de duas, seis e doze semanas. No período de uma semana esses materiais não apresentaram diferença estatística significante.

HACHMEISTER et al. ${ }^{43}$, em 2002, avaliaram a capacidade de selamento e retenção do agregado de trióxido mineral (MTA), quando utilizado como barreira apical em canais de dentes simulando rizogênese incompleta. As espessuras de MTA utilizadas foram de 1 e 4mm, e com ou sem a utilização do hidróxido de cálcio como medicação intracanal antes da colocação do MTA. Para avaliar a capacidade de selamento das barreiras apicais o método utilizado foi a infiltração bacteriana. As bactérias usadas foram Enterobacter aerogenes, Enterococcus faecalis e Staphylococcus epidermidis. Para avaliar a força necessária para provocar o deslocamento das barreiras apicais foi utilizado o teste de Instron. Com relação à infiltração bacteriana, 91\% dos canais que tiveram o MTA usado como barreira apical, tanto de $1 \mathrm{~mm}$ como de $4 \mathrm{~mm}$, apresentaram turbidez do meio após o décimo dia. Apenas E. aerogenes foi identificada nos meios de cultura turvos. Os testes feitos para avaliar o deslocamento da barreira apical mostraram que aquelas de $4 \mathrm{~mm}$ de espessura foram mais resistentes do que as de $1 \mathrm{~mm}$, havendo diferença estatística significante.

LEVENSTEIN $^{60}$, apoiando-se em um caso clínico realizado em 2002, relatou o uso do MTA na apicificação de um dente com rizogênese incompleta. Na primeira sessão, após a limpeza e a modelagem do canal, foi utilizado um curativo de hidróxido de cálcio. Na segunda sessão o canal foi irrigado com hipoclorito de sódio a 5\% e EDTA e, após a secagem do mesmo, um tampão apical de MTA de 3 a $4 \mathrm{~mm}$ de espessura foi feito. Uma bolinha de algodão umedecida foi colocada na entrada do canal e a cavidade de acesso foi selada com IRM; após 48 horas o paciente retornou e o tampão apical de MTA teve sua presa verificada por meio da inserção de um cone de papel e, então, foi realizada a obturação do canal. O autor constatou, depois de um ano, por meio de controles radiográficos, que o MTA induziu à formação de um tecido duro apical obliterando o ápice.

GIULIANI et al. ${ }^{40}$, também em 2002, demonstraram o uso do MTA como tampão apical em três casos clínicos de incisivos centrais superiores com ápices incompletos e lesões periapicais. Os canais foram irrigados com solução de hipoclorito de sódio a 5\% e uma pasta de hidróxido de cálcio foi deixada como curativo de demora por uma semana. Removida a pasta, na porção apical do canal foi colocado um tampão de MTA (4mm), e o restante do canal radicular foi obturado com guta-percha termoplastificada (Obtura II) e cimento. As avaliações, após seis meses e um ano, tanto 
clínica quanto radiográfica, mostraram que havia ocorrido o reparo das lesões periapicais.

Continuando o relato de casos clínicos, LYNN; EINBENDER ${ }^{65}$, em 2003, relataram o uso do agregado de trióxido mineral (MTA) com a finalidade de criar uma barreira apical em um dente permanente que sofreu trauma durante o seu processo de desenvolvimento, o que resultou na formação incompleta do ápice radicular. Devido ao trauma, o dente apresentava-se escurecido. Foi feita a abertura coronária e o canal foi instrumentado, sendo irrigado com hipoclorito de sódio. O canal foi seco e um tampão de MTA foi confeccionado, usando-se condensadores endodônticos e cones de papel para a adaptação do material no terço apical. Foi colocada uma bolinha de algodão úmida na câmara pulpar e a cavidade de acesso foi fechada com Cavit G. Uma semana depois, a paciente retornou para o término do tratamento endodôntico. Primeiramente, verificou-se a consistência do tampão de MTA e, então, realizou-se a obturação da porção remanescente do canal radicular com guta-percha e cimento endodôntico. Após seis meses, foram feitos os controles clínico e radiográfico, verificando-se a ausência de sintomatologia, assim como a neoformação de tecido ósseo periapical.

STEINIG; REGAN; GUTMANN ${ }^{99}$, em 2003, propuseram um método para a colocação do MTA, em uma sessão, em dentes com rizogênese incompleta. Primeiramente, esse método foi realizado in vitro para, posteriormente, ser aplicado in vivo. O método é composto por seis etapas, que seriam: a determinação do comprimento de trabalho, a seleção do condensador apropriado, a seleção do instrumento que levará o material à extensão desejada, a colocação do MTA, a colocação de um material intermediário, de preferência um cimento de ionômero de vidro e, por fim, a restauração com um compósito resinoso. Os autores apresentaram, ainda, um caso realizado in vivo com um ano de proservação, que mostrou o desaparecimento da área radiolúcida periapical, indicando o sucesso do tratamento.

No mesmo ano, LINSUWANONT ${ }^{61}$ relatou casos clínicos em que o MTA foi utilizado como tampão apical em casos de retratamento. $O$ autor relatou que, primeiramente, foi feita uma tentativa de se realizar a apicificação de incisivos centrais superiores utilizando uma pasta de hidróxido de cálcio, que seria trocada a cada três meses. Porém, como a paciente não compareceu à consulta para a realização da primeira troca, voltando ao consultório somente oito meses após o início do tratamento, optou-se pela colocação de uma barreira de MTA de 3 a 4mm, já que a pasta de hidróxido de cálcio não havia sido eficaz em criar uma barreira de tecido mineralizado. A paciente 
retornou no dia seguinte para a obturação da porção remanescente dos canais radiculares, que foi feita com o sistema Obtura II. Controles clínicos e radiográficos realizados seis meses e um ano após o término do tratamento mostraram o sucesso alcançado.

Em mais um caso clínico, MAROTO et al. ${ }^{69}$, em 2003, relataram o uso do MTA como tampão apical em um incisivo central com rizogênese incompleta e que havia sofrido intrusão. $O$ paciente de 9 anos de idade sofreu um acidente que provocou a intrusão dos incisivos centrais superiores. Trocas de curativo de hidróxido de cálcio haviam sido feitas a cada três meses, durante dois anos, com o objetivo de se conseguir a formação de uma barreira apical que possibilitasse a obturação dos canais radiculares. Apenas em um dos dentes (incisivo central esquerdo) essa barreira apical foi formada, e o canal foi obturado com guta-percha e cimento endodôntico. Já, no incisivo central direito, as trocas de curativo com hidróxido de cálcio, ainda, foram feitas por mais um ano. Porém, como não houve formação de barreira e a imagem radiolúcida apical ainda era persistente, decidiu-se confeccionar um tampão com MTA, de $2 \mathrm{~mm}$ de espessura e, após dois dias, realizou-se a obturação da porção remanescente do canal radicular. Após 12 meses, verificou-se a diminuição da imagem radiolúcida circunjascente ao ápice do incisivo central direito tratado com MTA, indicando que o processo de reparo estava ocorrendo.

AMINOSHARIAE; HARTWELL; MONN ${ }^{6}$, em 2003, realizaram um estudo para determinar se a adaptação marginal do MTA poderia diferir quando colocado em canais radiculares simulados, variando-se a espessura do material e a forma de colocação e condensação, nesses canais. Oitenta tubos de polietileno foram divididos em quatro grupos de 20 elementos cada. Os tubos foram preparados para receber $3 \mathrm{~mm}, 5 \mathrm{~mm}, 7 \mathrm{~mm}$ e $10 \mathrm{~mm}$ de MTA. Cada grupo de 20 tubos foi, assim, subdivido: 10 espécimes de cada espessura tiveram o MTA colocado e condensado pelo método manual e os outros 10 pelo método ultra-sônico. Após a condensação, os espécimes foram avaliados por meio de um microscópio de luz e também por radiografias, para verificar o grau de adaptação do MTA às paredes dos tubos e se havia espaços vazios no interior do próprio material. Os resultados demonstraram $80 \%$ de concordância entre a avaliação radiográfica e a microscópica. A condensação manual resultou em melhor adaptação às paredes do tubo e menos espaços vazios no interior do MTA quando comparada à condensação ultra-sônica, o que levou os autores a 
indicarem a condensação manual como o melhor método de se condensar o MTA no canal radicular.

MANGIN et al. ${ }^{67}$, em 2003, avaliaram a capacidade de selamento do MTA, do Super-EBA e de um cimento à base de hidroxiapatita frente à infiltração bacteriana quando usados como materiais retrobturadores. Foram utilizados 40 dentes humanos extraídos, divididos em três grupos experimentais de 10 espécimes cada, e dois grupos controles de 5 espécimes cada. O microrganismo utilizado para o teste de infiltração foi o Enterococcus faecalis. Os dentes tiveram as coroas seccionadas e, posteriormente, os canais foram instrumentados e as raízes apicectomizadas em três milímetros. Retrocavidades de $3 \mathrm{~mm}$ de profundidade foram preparadas com pontas de ultra-som e obturadas com os materiais testados. As raízes permaneceram em uma esponja embebida com solução salina a $37^{\circ} \mathrm{C}$ por 48 horas. Após esse período, as raízes foram fixadas no aparato utilizado para mensurar a infiltração, procedendo-se à realização das leituras. Os resultados mostraram que o MTA e o Super-EBA foram melhores que o cimento à base de hidroxiapatita, porém, não houve diferença estatisticamente significante entre os materiais testados.

Também avaliando a capacidade de selamento do Pro Root MTA, do MTAAngelus e do Super-EBA como materiais retrobturadores, SILVA NETO et al. ${ }^{89}$, em 2003, utilizaram 34 dentes unirradiculados de humanos, cujas coroas foram removidas, os canais radiculares instrumentados e, então, obturados com cimento de óxido de zinco e eugenol e cone único de guta-percha. Quarenta e oito horas após a obturação dos canais, as raízes foram apicectomizadas e cavidades retrógradas foram preparadas com pontas ultra-sônicas. A superfície externa de todas as raízes foi impermeabilizada com Araldite, e as mesmas divididas em três grupos experimentais e dois controles. Terminadas as retrobturações, as raízes foram imersas em solução de Rodamina B a $0,2 \%$ e mantidas em estufa a $37^{\circ} \mathrm{C}$, durante 48 horas. Após esse período, realizou-se o desgaste longitudinal da face mesial radicular, expondo a retrobturação e a marca da infiltração marginal. Os resultados mostraram que houve infiltração apical em todos os materiais, não havendo diferença estatística significante entre eles.

VALOIS; COSTA JR. ${ }^{111}$, em 2004, compararam a capacidade do MTA em prevenir a infiltração apical de um complexo protéico, quando utilizado em diferentes espessuras. Foram utilizados 64 dentes, os quais foram divididos em 4 grupos de 15 elementos e, dos 4 restantes, dois dentes foram usados para controle positivo e outros dois para controle negativo. Os dentes dos 4 grupos experimentais tiveram os canais 
obturados na região apical, com MTA, nas espessuras de 1, 2, 3 e 4mm. O grupo com $1 \mathrm{~mm}$ de espessura foi o menos efetivo em evitar a infiltração apical, enquanto o grupo com $4 \mathrm{~mm}$ de espessura ofereceu os melhores resultados.

HAYASHI; SHIMIZU; EBISU ${ }^{47}$, em 2004, relataram um caso clínico no qual o MTA foi utilizado como material obturador em dois incisivos centrais inferiores que já haviam sido tratados convencionalmente e também submetidos à cirurgia. $\mathrm{O}$ paciente, ao procurar tratamento, apresentava edema e fístula entre os incisivos centrais. Como havia duas coroas de porcelana nesses dentes, explicou-se ao paciente que o melhor tratamento seria a cirurgia parendodôntica, mas o paciente preferiu não se submeter à outra cirurgia. Por isso, optou-se pela remoção das coroas e dos núcleos. Deixou-se um curativo de hidróxido de cálcio por duas semanas e, após esse período, verificou-se a regressão da fístula. Outra aplicação de hidróxido de cálcio foi feita e, como o paciente não relatou dor e os canais apresentaram-se sem exsudato, foi feita a obturação dos mesmos com o MTA, utilizando-se um condensador e cones de papel. A espessura do material ficou em torno de 3 a $4 \mathrm{~mm}$ e, então, colocaram-se os núcleos metálicos e novas coroas de porcelana. Após dois anos de proservação, pôde-se notar o sucesso do tratamento, tanto radiográfico como clínico.

Também, em 2004, BRAMANTE; BORTOLUZZI; BROON ${ }^{20}$ demonstraram o uso do MTA como tampão apical por meio de um caso clínico e indicaram uma nova técnica de confecção do tampão de MTA. A técnica preconiza o uso de uma espiral Lentulo para a colocação do MTA no canal radicular, 2mm aquém do comprimento de trabalho, sendo que o MTA deve ser preparado numa consistência pastosa. A condensação deve ser feita com uma lima tipo K de calibre compatível com o do canal radicular e com a sua ponta envolta em algodão. Para a retirada do excesso do material recomenda-se a utilização de uma lima com a ponta envolta por algodão umedecido. Além disso, os autores afirmaram que a espessura do tampão apical deve ser de 3 a $4 \mathrm{~mm}$, o que garantiria o selamento apical.

LAWLEY et al. ${ }^{56}$, em 2004, avaliaram qual maneira de se levar o MTA ao canal radicular, via coronária, para ser utilizado como barreira apical, seria capaz de promover o melhor selamento deste material contra a infiltração bacteriana. Além disso, buscaram determinar se a utilização de resina composta intracanal ou guta-percha e cimento endodôntico colocados sobre a barreira apical de MTA promoveria maior resistência à fratura. O MTA foi colocado como barreira apical numa espessura de 
$4 \mathrm{~mm}$, com e sem vibração ultra-sônica. As barreiras foram expostas à infiltração bacteriana, e a resistência à fratura foi verificada aplicando-se forças utilizando-se o teste de Instron. Após 45 dias, os resultados estatísticos mostraram que o uso do ultrasom aumentou significativamente a capacidade de selamento do MTA, pois a infiltração bacteriana ocorreu em 6 dentes dos 18 utilizados no grupo que não fez uso do ultra-som e em 2 dos 18 utilizados no grupo em que o ultra-som foi utilizado. Com relação à resistência à fratura, o grupo em que se utilizou resina composta intracanal demonstrou maior resistência, sendo estatisticamente significante, quando comparado ao grupo em que se utilizou guta-percha e cimento endodôntico.

FERRIS; BAUMGARTNER ${ }^{38}$, em 2004, avaliaram a capacidade de dois tipos de agregado de trióxido mineral (MTA) em selar perfurações na região de furca em molares humanos extraídos, por meio da infiltração bacteriana. Quarenta molares humanos extraídos, superiores e inferiores, foram divididos aleatoriamente em dois grupos experimentais com 18 elementos cada. Dois dentes foram usados como controle positivo e dois, sem perfuração, serviram como controle negativo. Nos dentes do grupo 1 a perfuração foi selada com MTA cinza e nos do grupo 2, com o MTA branco. Os dentes foram montados em um modelo utilizado para se verificar a infiltração bacteriana, representada pelo Fusobacterium nucleatum. Os resultados mostraram que não houve diferença estatisticamente significante entre os dois tipos de MTA em prevenir a infiltração bacteriana.

Apresentando bons índices de sucesso, KRATCHMAN ${ }^{53}$, em 2004, relatou, por meio de casos clínicos, o uso do MTA, tanto o cinza quanto o branco, no reparo de perfurações e, também, como barreira apical em casos de dentes com ápices abertos. Para a obturação da porção remanescente do canal radicular, o autor sugeriu a utilização do sistema Obtura II.

Ainda, em 2004, VIZGIRDA et al. ${ }^{114}$ avaliaram o potencial do MTA como cimento obturador de canal radicular comparando sua capacidade de selamento com as proporcionadas pela obturação com guta-percha e cimento endodôntico pela técnica de condensação lateral e, também, pela técnica termoinjetora de guta-percha plastificada, utilizando o sistema Obtura II. Sessenta incisivos superiores de bovinos, com apenas um canal radicular, foram instrumentados utilizando-se o sistema LightSpeed. A seguir, foram divididos aleatoriamente em três grupos com vinte dentes cada e, então, obturados. O selamento apical foi analisado por meio da imersão dos dentes em solução 
corante de azul de metileno a $1 \%$, por três dias. A extensão linear da penetração do corante foi mensurada utilizando-se um estereomicroscópio. Os resultados mostraram que os canais obturados com guta-percha e cimento endodôntico, tanto pela técnica da condensação lateral como pela técnica termoinjetora, apresentaram menor infiltração apical, com significância estatística, em relação aos canais obturados com MTA.

MATT et al. ${ }^{71}$, em 2004, investigaram o uso do MTA como barreira apical comparando a capacidade de selamento e a dureza de dois tipos de MTA, o branco e o cinza. Foram utilizados 44 segmentos radiculares de $10 \mathrm{~mm}$ de comprimento, cujos canais foram preparados para simular ápices abertos. Para tal, os canais foram preparados com brocas de Gates Glidden, pela técnica coroa-ápice, da número 5 à número 1, até esta última ultrapassar o forame apical. Em seguida, os canais foram instrumentados com limas do tipo Flexofile até que a lima número 90 pudesse ser vista ultrapassando o forame apical em $1 \mathrm{~mm}$. O MTA, como tampão apical, foi colocado em duas espessuras, uma de $2 \mathrm{~mm}$ e outra de $5 \mathrm{~mm}$. Além disso, uma parte dos espécimes foi obturada imediatamente e a outra 24 horas após a colocação do MTA. Após a imersão dos dentes em azul de metileno pelo período de 48 horas, os mesmos foram seccionados para a avaliação da infiltração e a realização do teste de dureza dos tampões apicais. Os resultados mostraram que o MTA cinza apresentou menor infiltração do que o MTA branco, e que a técnica mediata mostrou-se superior à técnica imediata de obturação. $\mathrm{O}$ tampão apical de $5 \mathrm{~mm}$ foi, significantemente, superior ao de $2 \mathrm{~mm}$ quando avaliada a dureza, e isso ocorreu independentemente do tipo de MTA utilizado, bem como, do tipo de técnica de obturação realizada. Com isso, os autores sugeriram que o tampão apical com $5 \mathrm{~mm}$ de espessura, feito com MTA cinza e a obturação realizada em uma sessão posterior deveria ser a indicação para o tratamento de dentes com rizogênese incompleta.

Já, em 2005, AL-KAHTANI et al. ${ }^{5}$ simularam ápices incompletos em dentes permanentes para avaliar o selamento criado por tampões apicais de diferentes espessuras feitos com MTA. De acordo com os autores, a opção por testar diferentes espessuras de tampões apicais tem como principais razões o fato de que a colocação do MTA através de uma cavidade de acesso com mínima resistência à compressão na porção apical, devido à divergência das paredes dentinárias, pode dificultar o controle desse material para se obter a espessura desejada e, também, pelo fato de que a espessura do tampão apical irá determinar a profundidade de um possível núcleo 
protético usado para a restauração do dente. Assim, cinco grupos, com dez dentes cada, foram utilizados neste trabalho. O grupo 1 recebeu um tampão apical de $2 \mathrm{~mm}$ de MTA; no grupo 2 o tampão apical foi de $5 \mathrm{~mm}$ e no grupo 3 colocou-se um tampão de $2 \mathrm{~mm}$ e 24 horas depois foram colocados mais $2 \mathrm{~mm}$ de MTA. A porção remanescente do canal, nesses grupos, foi deixada vazia. O grupo 4 recebeu um tampão apical de $2 \mathrm{~mm}$ e após 24 horas o restante do canal foi obturado com guta-percha e cimento, enquanto o grupo 5 não recebeu tampão apical de MTA, sendo utilizado como controle positivo. $O$ selamento apical foi testado por meio da infiltração bacteriana, sendo utilizado o Actinomyces viscosus. Os resultados mostraram que o grupo 2, com $5 \mathrm{~mm}$ de espessura de tampão apical, exibiu diferença estatisticamente significante em relação aos demais, pois preveniu completamente a infiltração bacteriana.

KUBO; GOMES; MANCINI ${ }^{54}$, em 2005, avaliaram o selamento de cavidades retrógradas tratadas com diferentes agentes desmineralizantes e retrobturadas com agregado de trióxido mineral (MTA), mediante infiltração marginal de corante. Cinqüenta e seis dentes unirradiculados de humanos, extraídos, foram instrumentados, obturados, apicectomizados e tiveram retrocavidades preparadas com pontas ultrasônicas. A aplicação dos agentes desmineralizantes foi feita previamente à obturação das retrocavidades com MTA. Os espécimes foram divididos em quatro grupos de 14 dentes, como se segue: grupo 1 - nenhuma aplicação de qualquer agente desmineralizante; grupo 2 - aplicação de ácido fosfórico a 35\% durante 15 segundos; grupo 3 - aplicação de solução de EDTA a 17\%, pH 7, durante 3 minutos e grupo 4 aplicação de gel de EDTA a 24\%, pH 7, durante 4 minutos. A extensão da infiltração do corante (Rodamina B $0,2 \%$, a $37^{\circ} \mathrm{C}$, durante 24 horas) foi mensurada em milímetros, utilizando-se um microscópio óptico. Os resultados mostraram que o grupo que apresentou menor infiltração de corante foi o grupo 1, porém, não houve diferença estatisticamente significante em relação aos demais grupos.

Também, em 2005, XAVIER et al. ${ }^{121}$ avaliaram a capacidade de selamento de alguns materiais retrobturadores, por meio da microinfiltração de corante, e a adaptação marginal utilizando-se de um microscópio eletrônico de varredura. Trinta dentes unirradiculados de humanos foram utilizados. Os dentes tiveram as coroas seccionadas, de modo a deixar as raízes com um comprimento aproximado de $16 \mathrm{~mm}$. Os canais foram instrumentados e, posteriormente, obturados com guta-percha e cimento à base de óxido de zinco e eugenol (Endofill). As raízes foram, então, 
seccionadas apicalmente e retrocavidades com $3 \mathrm{~mm}$ de profundidade foram preparadas com pontas ultra-sônicas. A seguir, as raízes foram divididas em três grupos experimentais de 10 espécimes cada: grupo 1: retrobturadas com MTA-Angelus; grupo 2: retrobturadas com Super-EBA e grupo 3: retrobturadas com Vitremer. As superfícies radiculares externas foram isoladas com esmalte para unhas e os dentes foram imersos em nitrato de prata por uma hora. As raízes foram seccionadas transversalmente em cada um dos 3mm obturados, resultando em três secções denominadas de A, B e C, que foram levadas a um estereomicroscópio para a observação da infiltração do corante. Por meio do microscópio eletrônico de varredura (M.E.V.), o espaço entre os materiais retrobturadores testados e a dentina adjacente foi mensurado em quatro pontos, mas apenas nas secções $\mathrm{A}$ e $\mathrm{B}$, pois a secção $\mathrm{C}$ representava a união do material retrobturador à guta-percha e ao cimento endodôntico. A análise estatística mostrou diferença significante entre os três materiais em relação à capacidade de selamento, sendo que o Vitremer apresentou o pior resultado. Em relação à adaptação marginal, o MTA-Angelus apresentou os melhores resultados.

AL-HEZAIMI et al. ${ }^{4}$, em 2005, analisaram a capacidade de selamento do agregado de trióxido mineral (MTA), usado como material obturador de canal radicular em prevenir a infiltração de saliva humana, in vitro. Quarenta e três dentes humanos extraídos, unirradiculados, tiveram os canais instrumentados até o ápice com um instrumento número 40/0.6 e, então, foram obturados com MTA cinza (grupo A), MTA branco (grupo B) ou guta-percha e cimento endodôntico Kerr Pulp Canal Sealer EWT (grupo C). Os dentes foram montados em um modelo para testar a infiltração salivar. Após 42 dias, um dente do grupo A (9,1\%), quatro do grupo B (36,4\%) e nove do grupo C $(81,8 \%)$ apresentaram infiltração. Estatisticamente, verificou-se diferença entre os grupos A e C. De acordo com o estudo, os dois tipos de MTA parecem ser mais resistentes à infiltração de saliva do que a obturação convencional com guta-percha e cimento endodôntico à base de óxido de zinco e eugenol.

HAM et al. ${ }^{44}$, em 2005, avaliaram a expressão de BMP-2 e as características histológicas, usando hidróxido de cálcio e MTA, durante o processo de apicificação. Nos cinco macacos utilizados neste estudo (Macaca fascicularis), três dos quatro quadrantes da boca tiveram os dentes infectados pela exposição pulpar à saliva. Após 30 dias, houve a formação de quatro grupos, obedecendo sempre a mesma disposição em todos os macacos, sendo, grupo I - quadrante superior direito (controle positivo): dentes 
não infectados, grupo II - quadrante superior esquerdo: canais tratados com MTA, grupo III - quadrante inferior esquerdo: canais tratados com hidróxido de cálcio e grupo IV - quadrante inferior direito: canais não tratados (controle negativo). Noventa dias após o tratamento, os animais foram sacrificados e áreas contendo a região apical de cada quadrante foram analisadas. A avaliação histológica mostrou que o grupo tratado com MTA apresentou menor processo inflamatório quando comparado aos grupos controle negativo e do hidróxido de cálcio. Além disso, no grupo tratado com MTA, a formação de uma barreira apical também foi maior em relação aos grupos III e IV. Em relação à expressão de BMP-2, os resultados mostraram que os grupos tratados com MTA e hidróxido de cálcio tendem a ser mais imunoreativos à BMP-2 do que o grupo que não recebeu tratamento.

CONEGLIAN; BRAMANTE; OROSCO ${ }^{27}$, em 2005, avaliaram a capacidade de selamento apical dos MTA-Angelus branco e cinza e do cimento Portland branco, colocados via canal, variando-se a espessura do tampão apical. Os canais de noventa raízes foram instrumentados, tendo a lima tipo K número 60 como instrumento de memória e a 40 para se padronizar a abertura foraminal. A seguir, as raízes foram divididas em três grupos de trinta, de acordo com os materiais utilizados; grupo A: MTA-Angelus cinza; grupo B: MTA-Angelus branco e grupo C: cimento Portland branco. Subseqüentemente, cada grupo foi subdividido em três grupos de dez raízes, em função das espessuras dos tampões apicais $(2,5$ e $7 \mathrm{~mm})$. A infiltração foi marcada utilizando-se o corante Rodamina B a $0,2 \%$, por 72 horas, em estufa a $37^{\circ} \mathrm{C}$. A menor infiltração foi constatada nos tampões de 5 e $7 \mathrm{~mm}$ de espessura, e não se encontrou diferença entre o MTA-Angelus cinza e o cimento Portland branco. O MTA-Angelus branco foi o que apresentou a maior infiltração marginal, com diferença estatisticamente significante em relação aos demais.

No ano de 2006, FIDEL et al. ${ }^{39}$ descreveram o tratamento, em um incisivo inferior esquerdo, de ápice incompletamente formado e que sofreu fratura coronária, em um paciente de 12 anos de idade. Após os procedimentos endodônticos convencionais e medicação intracanal com pasta de hidróxido de cálcio, que foi trocada em intervalos de 3 meses, durante 1 ano, foi confeccionado um tampão apical com agregado de trióxido mineral, na tentativa de se evitar o extravasamento de guta-percha e cimento endodôntico para os tecidos periapicais. A proservação, realizada 2 anos após, 
demonstrou que o dente se encontrava assintomático e o exame radiográfico mostrou o reparo completo da lesão apical.

ANDREASEN; MUNKSGAARD; BAKLAND ${ }^{7}$, em 2006, compararam a resistência à fratura de dentes de ovelha, com rizogênese incompleta, após a obturação dos canais radiculares com hidróxido de cálcio ou MTA. Trinta incisivos, com aproximadamente $80 \%$ do seu desenvolvimento, foram removidos após o sacrifício dos animais e divididos em quatro grupos experimentais. As polpas de todos os dentes foram extirpadas via apical. No grupo A, os dentes foram preenchidos com solução salina e mantidos nesta mesma solução por 100 dias a $6^{\circ} \mathrm{C}$. No grupo $\mathrm{B}$, os dentes foram obturados com hidróxido de cálcio e selados apicalmente com IRM, também sendo mantidos em solução salina por 100 dias a $6^{\circ} \mathrm{C}$. No grupo $\mathrm{C}$, os dentes foram obturados com MTA e no grupo D foram obturados com hidróxido de cálcio que, após 30, dias foi retirado do canal e substituído por MTA. Os dentes desses grupos também foram armazenados por um período de 100 dias em solução salina a $6^{\circ} \mathrm{C}$. Após esse período, todos os dentes foram colocados em blocos de gesso Paris para que a resistência à fratura fosse testada utilizando-se o teste de Instron. Os resultados mostraram uma diminuição da resistência à fratura nos dentes que foram obturados com hidróxido de cálcio, quando comparados aos demais grupos. Os autores constataram que, quando o hidróxido de cálcio foi mantido no canal radicular por 30 dias e, após esse tempo, foi substituído pelo MTA, não ocorreu decréscimo na resistência dos dentes.

XU et al. ${ }^{123}$, em 2006, avaliaram, clinicamente, o efeito MTA, como barreira apical, no tratamento de dentes com ápices abertos. Vinte e três dentes com ápices abertos tiveram os canais limpos, instrumentados e preenchidos com pasta de hidróxido de cálcio. Após a retirada da pasta, o MTA foi levado ao canal radicular de modo a criar barreiras apicais de 3 a $5 \mathrm{~mm}$ de espessura. A porção remanescente do canal foi obturada utilizando guta-percha (sistema Obtura II) e o cimento endodôntico AH Plus. Todos os pacientes retornaram para a realização dos controles clínico e radiográfico após duas ou três semanas. O controle radiográfico mostrou que sete casos apresentaram sobreobturação de 1 a $2 \mathrm{~mm}$, enquanto os outros dezesseis ficaram bem obturados. Além disso, os dentes que apresentavam, previamente, área radiolúcida na região periapical, mostraram uma diminuição e/ou o completo desaparecimento da mesma. Todos os pacientes apresentaram-se assintomáticos. 
Em outro estudo realizado por XU et al. ${ }^{122}$, também em 2006, foi comparado o tratamento de dentes com ápices incompletos, em adultos, feitos com MTA e com Vitapex, que é uma pasta composta por hidróxido de cálcio (30,3\%), iodofórmio (40,4\%), óleo de silicone $(22,4 \%)$ e outras substâncias não descritas $(6,9 \%)$, de fabricação japonesa. Assim, 41 dentes anteriores e pré-molares com apenas um canal tiveram os canais instrumentados e preenchidos com hidróxido de cálcio. $\mathrm{O}$ grupo experimental foi composto por 21 dentes, em que foram feitos tampões apicais de MTA de 3 a $5 \mathrm{~mm}$ de espessura, seguidos de obturação com guta-percha (sistema Obtura II) e cimento endodôntico (AH Plus). Os 20 dentes restantes (grupo controle) tiveram os canais tratados com Vitapex. Após a detecção da formação de barreira apical, os canais foram obturados de maneira semelhante à do grupo experimental. Os resultados foram satisfatórios para a maioria dos casos do grupo experimental. A radiografia pósoperatória mostrou que 15 canais foram bem obturados, enquanto que em 6 casos ocorreu sobreobturação (de 0,5 a $2 \mathrm{~mm}$ ). As radiografias de controle pós-operatório mostraram uma diminuição das áreas radiolúcidas pré-existentes ou o completo desaparecimento das mesmas, com exceção de um caso. No grupo controle, a apicificação ocorreu em 11 casos, falhando nos 9 restantes. A média de visitas para a realização do controle radiográfico, durante um ano, foi de 3,5 para o grupo experimental e de 6 para o grupo controle. Já a média para a completa realização do tratamento endodôntico foi de 11,8 dias para o grupo experimental e de 306, 8 para o controle. Os autores concluíram que o MTA foi mais rápido e efetivo no tratamento de dentes com ápices incompletos em adultos.

Também em 2006, EL-MELIGY; AVERY ${ }^{32}$ compararam o agregado de trióxido mineral (MTA) e o hidróxido de cálcio, clínica e radiograficamente, como materiais utilizados para induzir a formação de barreira apical em dentes permanentes com necrose pulpar e rizogênese incompleta. Quinze crianças, cada uma com, pelo menos, dois dentes permanentes com necrose pulpar e que necessitavam de tratamento para induzir a apicificação foram selecionadas para esse estudo. Os dentes selecionados foram, aleatoriamente, divididos em dois grupos. No grupo 1 o tratamento foi realizado utilizando-se o hidróxido de cálcio, enquanto que no grupo 2 o material usado foi o MTA. As crianças foram chamadas para reavaliações clínicas e radiográficas após 3, 6 e 12 meses. Dos quinze dentes tratados com o hidróxido de cálcio, dois apresentaram falhas no tratamento, já que aos 6 e aos 12 meses foi verificado que os mesmos 
apresentavam inflamação periapical persistente e sensibilidade à percussão. Já os quinze dentes que foram tratados com o MTA não mostraram qualquer sinal clínico ou radiográfico de patologia periapical.

FELIPPE; FELIPPE; ROCHA ${ }^{36}$, ainda em 2006, avaliaram a influência do MTA na apicificação e no reparo da região periapical de dentes de cães com rizogênese incompleta e canais radiculares previamente contaminados, além da verificação da necessidade de emprego da pasta de hidróxido de cálcio como curativo de demora antes do uso do MTA. Para isso, vinte pré-molares de dois cães de seis meses de idade foram usados. Após o acesso aos canais radiculares e a remoção da polpa, os mesmos permaneceram expostos ao ambiente bucal por duas semanas. Após esse período, os canais foram instrumentados, secos, e dois pré-molares, em cada cão, foram utilizados como controle, em que os canais foram deixados vazios. Os outros oito dentes, em cada animal, foram divididos em dois grupos experimentais. No grupo 1, o terço apical dos canais radiculares foi obturado com MTA. No grupo 2, foi colocada uma pasta de hidróxido de cálcio, tendo como veículo o propilenoglicol. Após uma semana, a pasta foi removida e o terço apical dos canais foi obturado com MTA. Os dentes foram restaurados com IRM e amálgama. Os animais foram sacrificados 5 meses mais tarde, e blocos de dente e tecidos adjacentes foram submetidos ao processamento histológico. Os cortes foram estudados para avaliar sete parâmetros: formação de barreira apical calcificada; nível da formação da barreira; presença de reação inflamatória; reabsorções radicular e óssea; extrusão de MTA e presença de microrganismos. Resultados significativos foram encontrados em relação à posição da formação da barreira e também da extrusão de MTA. A barreira foi formada no interior do canal em 69,2\% das raízes do grupo 1, enquanto no grupo 2 essa formação se deu além dos limites das paredes do canal em $75 \%$ das raízes. A extrusão de MTA ocorreu, principalmente, nas raízes do grupo 2, e nos demais parâmetros houve similaridade entre os grupos.

Também, em 2006, STUART; SCHWARTZ; BEESON ${ }^{100}$ realizaram um estudo comparando o reforço e a capacidade de resistência do Resilon, da guta-percha e de uma resina (Bisfil 2B) em dentes com ápices incompletos, selados com MTA e submetidos ao tratamento endodôntico. Para isso, sessenta dentes unirradiculados foram divididos em cinco grupos com doze dentes cada, e todos os dentes, com exceção do grupo controle negativo, foram preparados com uma broca de Peeso número 5 (1,5mm de diâmetro) ultrapassando o forame apical, para simular dentes com ápices 
incompletos, e os canais foram obturados com uma barreira de 4mm de MTA. A seguir, a porção remanescente dos canais dos três grupos experimentais foi obturada com gutapercha, Resilon e Bisfil 2B. No grupo controle positivo, o restante do canal não foi obturado, enquanto no controle negativo os canais não receberam qualquer tipo de tratamento. Uma fratura horizontal foi feita em cada raiz de cada espécime usando uma máquina Instron. Os resultados mostraram não haver diferença estatística significante entre os grupos, o que levou os autores a concluírem que o reforço de dentes com canais que tenham 1,5mm de diâmetro, ou menos, pode não ser necessário.

Buscando uma forma de facilitar a colocação do MTA no canal radicular, YEUNG; LIEWEHR; MOON ${ }^{126}$, em 2006, realizaram um estudo comparando a densidade desse material, produzida pela condensação manual e pela condensação manual com ativação ultra-sônica. Sessenta blocos de acrílico com canais estreitos ou curvos foram instrumentados até o instrumento de diâmetro 45, e pesados em uma balança eletrônica digital. Em 30 espécimes escolhidos aleatoriamente, os canais foram obturados com MTA pela técnica de condensação manual e, então, pesados. O MTA foi removido, os canais foram lavados e secos e, novamente obturados, desta vez usando a condensação manual com ativação ultra-sônica. Nos outros 30 espécimes, o procedimento realizado foi o mesmo, porém, de maneira inversa. Os blocos foram pesados novamente, e o peso da obturação com MTA produzido pelas duas técnicas de colocação foi analisado estatisticamente. Os resultados mostraram que a condensação manual com ativação ultra-sônica resultou em obturações mais pesadas e, também, mais densas, do que aquelas feitas apenas com a condensação manual, sendo a diferença estatisticamente significante.

Em 2006, VASCONCELOS ${ }^{112}$ avaliou o pH, a liberação de íons cálcio, o tempo de presa e a solubilidade de vários cimentos, entre eles o ProRoot MTA ${ }^{\circledR}$, o MTA-Angelus ${ }^{\circledR}$ cinza, o MTA-Angelus branco e um MTA-experimental, desenvolvido na UNESP de Ilha Solteira - SP. Os ensaios que se prestaram para a avaliação das propriedades físico-químicas foram realizados conforme a norma \#57 da ADA, excetuando-se a determinação do tempo de presa, onde foi incluída a utilização da agulha de Gilmore de 453,6g, conforme recomenda a norma \#C266-03 da ASTM. Os resultados demonstraram que todos os cimentos avaliados apresentam $\mathrm{pH}$ alcalino e foram capazes de liberar íons cálcio em quantidades bastante semelhantes, com tendência de redução nos períodos mais longos. Quanto aos tempos de presa, os cimentos da empresa Angelus ${ }^{\circledR}$ foram os que apresentaram os menores tempos. 
Considerando-se o ensaio de solubilidade, todos os cimentos enquadraram-se dentro das recomendações da ADA, apresentando valores próximos a 1,0\%.

\subsection{Cimento CPM ${ }^{\circledR}$ (Cimento Portland Modificado)}

Como relatou $\mathrm{CASTRO}^{24}$, em 2003, trata-se de um cimento Portland modificado, de cor branca, com características especiais de plasticidade, aderência, tamanho das partículas, $\mathrm{pH}$, tolerância biológica, histocompatibilididade, estimulação osteogênica e escoamento. Entre as aplicações clínicas do $\mathrm{CPM}^{\circledR}$ encontram-se, de modo geral, os tratamentos sobre polpas vitais e polpas necróticas. Assim, pode-se aplicar o $\mathrm{CPM}^{\circledR}$ como material capeador pulpar direto e indireto, em casos de pulpotomia, de reabsorções externas e internas. Em casos de polpas necróticas, é possível utilizá-lo como barreira apical, indutora de formação de tecido mineralizado, e em dentes imaturos necrosados por trauma. No caso do tratamento de perfurações dentais, radiculares ou de furca, o objetivo é manter os tecidos periodontais saudáveis em torno do dente perfurado. Também pode ser utilizado em fraturas transversais, como material obturador permanente em grandes lesões apicais e laterais, resultantes de processos patológicos e/ou traumáticos agudos e crônicos, luxações ou reimplantes. Por outro lado, também pode ser utilizado como tampão apical para a obturação dos canais radiculares com outros materiais de uso endodôntico, com o objetivo de se evitar o extravasamento de material para os tecidos periapicais. $O$ autor afirma que $o$ extravasamento de $\mathrm{CPM}^{\circledR}$ não implica riscos biológicos, pois o material apresenta excelente tolerância biológica, ausência de mutagenicidade e, também, de potencial carcinogênico. Ainda, segundo o autor, devido à estabilidade dimensional, o $\mathrm{CPM}^{\circledR}$ oferece excelente propriedade de selamento marginal. Como características gerais, o $\mathrm{CPM}^{\circledR}$ apresenta-se substancialmente livre de óxido de ferro, ou de conteúdo muito baixo, por volta de $0,5 \%$; apresenta melhor plasticidade e menor tamanho de partículas de pó, em relação a outros agregados de trióxidos minerais; tem capacidade osteoindutora; menor tempo de trabalho; estabilidade química e dimensional ao longo do tempo; contém uma altíssima concentração de íons cálcio no sítio de aplicação, que diminui a permeabilidade capilar e o extravasamento de plasma, favorecendo o processo de regeneração biológica; possui um pH em torno de 9,4 a 10, que possibilita a ativação da fosfatase alcalina; permite a adesão de carbonato de cálcio, às expensas do qual se 
forma a barreira de osteocemento durante o reparo de lesões ósseas e dentárias; menor tempo de presa; não apresenta em sua composição mercúrio e chumbo; suas principais moléculas são o cálcio e o fósforo; sua resistência à compressão é de 70MPa. Assim como o MTA, o $\mathrm{CPM}^{\circledR}$ também possui propriedade hidrofílica, podendo ser utilizado nas presenças de umidade e sangue.

Já, em 2006, VASCONCELOS ${ }^{112}$ avaliou algumas propriedades físicoquímicas de vários cimentos, dentre eles o $\mathrm{CPM}^{\circledR}$. Esse cimento apresentou $\mathrm{pH}$ alcalino e foi capaz de liberar íons cálcio, porém, com tendência de redução nos períodos mais longos. Quanto aos tempos de presa, o $\mathrm{CPM}^{\circledR}$ apresentou valores intermediários entre os tempos de presa apresentados pelos outros cimentos avaliados. Considerando-se o ensaio de solubilidade, a média, em porcentagem, obtida pelo $\mathrm{CPM}^{\circledR}$, foi de $0,91 \%$, estando dentro do valor máximo permitido pela ADA.

Ainda, em 2006, BRAMANTE et al. ${ }^{21}$ apresentaram algumas vantagens do $\mathrm{CPM}^{\circledR}$ em relação ao amálgama e aos compostos derivados do óxido de zinco e eugenol, destacando-se, entre outras, o excelente selamento marginal, impedindo a migração bacteriana e dos fluidos tissulares para o interior do canal, e também o tamanho adequado das partículas do pó, conferindo ao material boa aderência às paredes do canal radicular. Além disso, relatam as indicações clínicas do $\mathrm{CPM}^{\circledR}$, destacando-se os casos de proteção pulpar direta, pulpotomia, perfurações e reabsorções radiculares, cirurgias parendodônticas e como tampão apical em dentes com rizogênese incompleta.

\subsection{Cimento MBPc [Moraes e Berbert Pasta (cirurgia)]}

MORAES ${ }^{74}$, em 1984, realizou 30 experimentos com a intenção de obter novos cimentos epóxicos viáveis para a obturação de canais radiculares. Foram feitos testes de alterações de cor, textura e volume, de radiopacidade, de consistência e tempo de presa, buscando outros radiopacificadores e resinas tipo bisfenol A e respectivos endurecedores. Terminados os 30 experimentos, chegou-se a 4 formulações, que foram submetidas aos mesmos testes para comparações com outros materiais obturadores de canais radiculares, como o AH26 original ou com hidróxido de cálcio, o óxido de zinco e eugenol e guta-perchas de diversas procedências. Além desses testes, também foi feito o de infiltração marginal, no qual duzentos e dezesseis dentes unirradiculados tiveram 
os canais instrumentados e obturados com os cimentos experimentais ou com o AH26 ou com o óxido de zinco e eugenol. As suas superfícies foram impermeabilizadas, exceto próximo ao forame apical, e os dentes foram imersos em solução de azul de metileno a $2 \%$, permanecendo por 72 horas ou 30 dias. Os resultados mostraram que, dentro de padrões clínicos aceitáveis, pelo menos um dos cimentos experimentais apresentou desempenho destacado em relação ao AH26 e ao cimento de óxido de zinco e eugenol.

PAVAN $^{77}$, em 1999, analisou a infiltração marginal em obturações retrógradas, utilizando 80 dentes anteriores humanos extraídos. Os dentes foram distribuídos aleatoriamente em quatro grupos de 20 espécimes cada, de acordo com os materiais retrobturadores utilizados. Os canais foram instrumentados e, então, obturados. Em seguida, realizou-se a ressecção da porção apical e confeccionaram-se retrocavidades com uma broca esférica número 2 , com ponta ativa de $2 \mathrm{~mm}$. As raízes foram impermeabilizadas com duas camadas de Araldite e duas camadas de esmalte para unhas. As retrobturações foram, então, realizadas com os seguintes materiais: grupo I - polímero de mamona, grupo II - epóxico experimental, grupo III - Super-EBA e grupo IV - ionômero de vidro. Posteriormente, os espécimes foram imersos em solução corante de azul de metileno a $2 \%$, a $37^{\circ}$, por 48 horas. Após a lavagem dos dentes e a retirada da impermeabilização, as raízes foram seccionadas longitudinalmente, expondo-se as retrobturações e marcas da infiltração do corante. Para a avaliação da infiltração da solução de azul de metileno a $2 \%$ os espécimes foram escaneados para a utilização do programa SigmaScan, realizando, assim, as medições lineares das infiltrações. Os resultados indicaram que o grupo que apresentou a menor infiltração foi o grupo I - polímero de mamona, seguido pelo grupo II - epóxico experimental, grupo IV - ionômero de vidro e grupo III - Super-EBA, com diferença estatisticamente significante entre os grupos I e III. Vale ressaltar que o cimento epóxico experimental, testado nesse trabalho, foi um precursor do MBPc.

Também em 1999, BRANDÃO ${ }^{22}$ avaliou os cimentos resinosos Sealer 26, Sealer Plus e MBP, uma versão do MBPc, utilizado para obturação de canais, sendo os dois últimos, experimentais. Como controle, foi utilizado o cimento de óxido de zinco e eugenol. Foram realizados os testes de escoamento, tempo de presa e radiopacidade, segundo a norma ISO/DIS 6876, além dos testes de infiltração marginal apical, pH e liberação de cálcio. Os resultados mostraram que todos os cimentos apresentaram 
escoamento, tempo de presa e radiopacidade satisfatórios. O cimento de óxido de zinco e eugenol foi o único a apresentar média de infiltração marginal apical acima de $0,4 \mathrm{~mm}$. Quanto ao pH, os cimentos Sealer 26 e MBP apresentaram valores acima de 9,0 aos 30 dias. Em relação à liberação de cálcio, o MBP apresentou maiores valores aos 30 dias, sempre crescentes ao longo do tempo. Foram comprovadas as boas propriedades do cimento Sealer 26, enquanto o cimento MBP foi considerado bastante promissor.

Em 2002, SILVA NETO $^{87}$ analisou a capacidade seladora e a adaptação marginal, in vitro, de alguns materiais quando utilizados em perfurações na região de furca. Utilizaram-se cento e quatro dentes molares humanos extraídos, superiores e/ou inferiores, dos quais oitenta e oito foram usados para analisar o selamento, por meio da infiltração da solução corante de Rodamina B a $0,2 \%$, e dezesseis para a adaptação marginal, por meio da microscopia eletrônica de varredura. As perfurações foram obturadas com os seguintes materiais: grupo I - MTA-Angelus, grupo II - Pro Root MTA, grupo III - Super-EBA e grupo IV - MBPc. Antes da obturação, porém, cada grupo foi dividido em dois subgrupos, um recebendo uma matriz de gesso Paris no fundo da perfuração e o outro não. A leitura da infiltração marginal foi realizada por meio de um microscópio óptico, utilizando-se de escores numéricos - 0, 1, 2 e 3 - para sua quantificação. Para a visualização da adaptação marginal dos materiais obturadores às paredes dentinárias, os espécimes foram submetidos ao microscópio eletrônico de varredura (M.E.V.), obtendo-se fotomicrografias com aumentos de 50 e 200X. Quanto à infiltração, os resultados mostraram que o cimento MBPc, quando utilizado sem a matriz de gesso Paris, apresentou os menores índices de infiltração marginal, seguido pelo Super-EBA, havendo diferença estatística entre esses e os cimentos MTA-Angelus e ProRoot MTA. Na presença da matriz de gesso Paris, o MBPc também foi superior aos demais cimentos, havendo diferença estatística entre ele e os cimentos MTAAngelus e Pro Root MTA.

SIQUEIRA et al. $^{90}$, em 2004, avaliaram comparativamente, in vitro, a microinfiltração bacteriana permitida por retrobturações realizadas com Pro Root MTA, MTA Angelus cinza, MBPc e cimento Portland. Para isso, noventa e dois dentes unirradiculados de humanos foram aleatoriamente divididos em quatro grupos de 20 espécimes cada, que receberam os materiais experimentais, e dois grupos controles. Os dentes tiveram as coroas removidas e, então, os canais foram instrumentados e, a seguir, apicectomizados, e os materiais retrobturadores foram inseridos em retrocavidades de 
$3 \mathrm{~mm}$ de profundidade. Para impedir a passagem de bactérias por canais laterais, aplicou-se Araldite em toda a superfície radicular externa, exceto sobre a superfície apicectomizada. As raízes foram inseridas em tubos de microcentrífuga (eppendorf), fixadas com Araldite e mantidas em ambiente úmido durante 15 dias, sendo, então, esterilizadas em óxido de etileno. O conjunto (raiz e tubo de microcentrífuga) foi montado em frascos tipo penicilina, e o Enterococcus faecalis foi inoculado dentro do tubo de microcentrífuga. $\mathrm{O}$ aparato permaneceu em estufa a $37^{\circ} \mathrm{C}$ durante 50 dias. Nesse período, ocorreu infiltração em apenas um espécime de cada grupo experimental.

Em 2006, CINTRA et al. ${ }^{26}$ avaliaram, quantitativa e qualitativamente, a resposta inflamatória e a formação óssea frente ao implante de tubos de polietileno em alvéolos dentários de ratos, contendo o cimento experimental MBPc, que contém hidróxido de cálcio, comparando-o ao cimento ProRoot MTA. Foram utilizados 48 ratos, divididos aleatoriamente em três grupos. No grupo I, foram introduzidos no alvéolo dentário, após a extração do respectivo elemento, tubos de polietileno vazios que serviram de controle para os grupos experimentais. No grupo II foram implantados tubos contendo o cimento ProRoot MTA e no grupo III o cimento experimental MBPc. Após 7, 15 e 30 dias da realização do implante os animais foram sacrificados e as hemimaxilas direitas, que continham os alvéolos e os tubos implantados, foram removidas e processadas em laboratório para a análise em microscopia de luz. Os resultados demonstraram que ambos os materiais tiveram comportamento biológico semelhante, não apresentando diferença estatisticamente significante.

VASCONCELOS ${ }^{112}$, em 2006, comparou o MBPc a vários cimentos, avaliando o pH, a liberação de íons cálcio, o tempo de presa e a solubilidade. O MBPc apresentou $\mathrm{pH}$ alcalino em todos os períodos analisados, assim como foi capaz de liberar íons cálcio, porém, nos dois testes, houve diminuição dos valores nos períodos mais longos. Com relação aos tempos de presa, esse cimento apresentou os maiores valores, tanto de presa inicial (121 minutos) como final (224 minutos), em média. Já o valor médio obtido no teste de solubilidade foi de 1,07\%, enquadrando-se nas recomendações da ADA. 
3 - PROPOSIÇÃO 


\section{PROPOSIÇÃO}

A revisão da literatura mostrou ser oportuna e viável a realização deste trabalho, conforme foi exposto na introdução. Assim, nos propusemos a confeccionar tampões apicais com os cimentos MTA-Angelus ${ }^{\circledR}$ cinza, CPM $^{\circledR}$ e MBPc, em dentes permanentes com forames apicais ampliados, e avaliar:

3.1 A capacidade de selamento proporcionada pelos tampões;

3.2 A adaptação dos tampões às paredes dos canais radiculares;

3.3 A influência de três técnicas de obturação de canais radiculares, na capacidade de selamento e adaptação dos tampões. 


\section{4 - MATERIAL E MÉTODOS}




\section{MATERIAL E MÉTODOS}

\subsection{Avaliação da capacidade seladora por meio da infiltração de Rodamina B.}

Foram utilizados 120 dentes permanentes de humanos, unirradiculados e portadores de um canal, superiores ou inferiores, com raízes íntegras e ápices completamente formados, provenientes do arquivo de dentes da disciplina de Endodontia da FOB-USP e obtidos antes de 1996, e que foram conservados em solução aquosa de formol a $10 \%$ até o momento do uso.

A abertura coronária foi realizada com pontas diamantadas esféricas número 1013 e tronco-cônicas 3082 (K.G. Sorensen Indústria e Comércio Ltda, São Paulo, Brasil) em alta rotação. O preparo dos canais radiculares foi feito, inicialmente, pela técnica coroa-ápice, com brocas de Gates Glidden (Dentisply-Maillefer Instuments SA, Ballaigues, Suíça) em ordem numérica decrescente, partindo-se da broca número 5 até a de número 1. Esta sempre ultrapassou o forame apical em 1mm (Figura 1).

Após esse procedimento, os canais foram dilatados, ainda, com limas do tipo K (Dentsply-Maillefer Instuments SA, Ballaigues, Suíça), iniciando-se com a de número 50 até a de número 90, padronizando-se, assim, o diâmetro do forame. Durante a instrumentação, todas as limas ultrapassaram o forame apical em 1mm (Figura 2). 

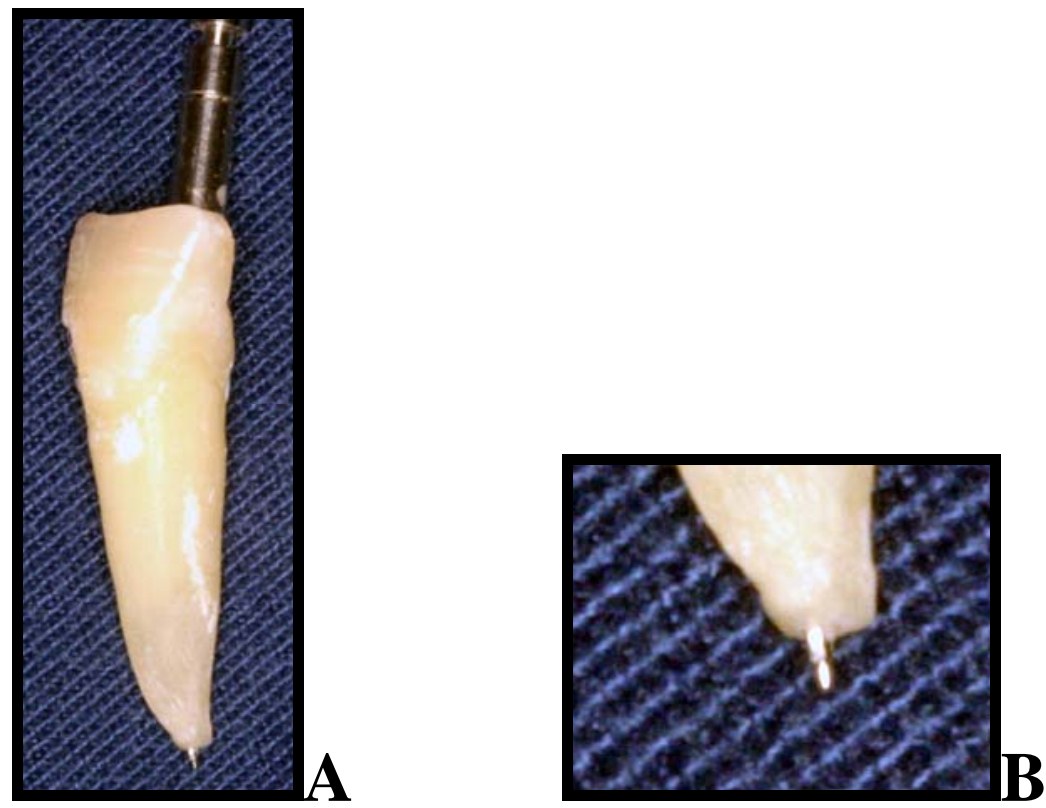

Figura 1 A e B - A: Broca de Gates-Glidden número 1 ultrapassando o forame apical em 1mm.; B: Ampliação da área apical observada na Figura 1A.
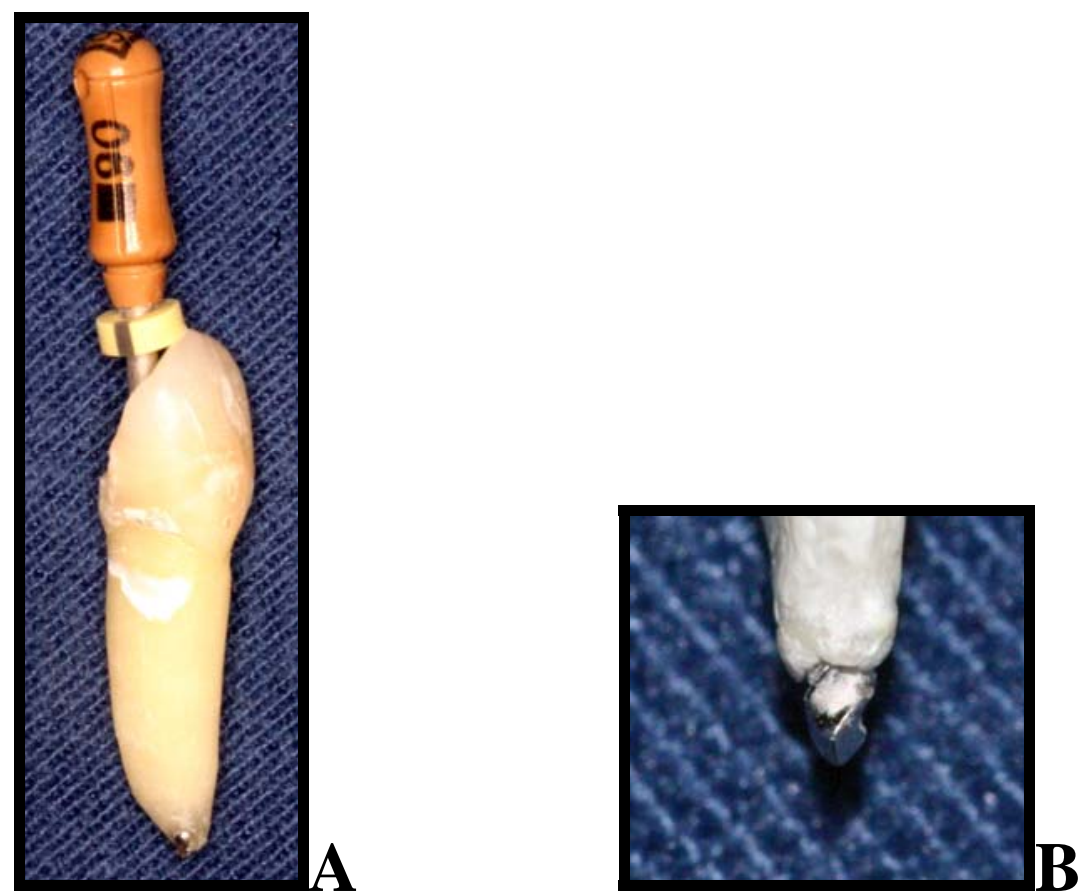

Figura 2 A e B - A: Lima número 90 ultrapassando o forame apical em 1mm.; B: Ampliação da área apical de outro dente mostrando o trespasse apical da lima, em 1mm.

A cada troca de instrumento, os canais eram irrigados com $1 \mathrm{~mL}$ de hipoclorito de sódio a 1\% (Biodinâmica Química e Farmacêutica Ltda, Ibiporã, Brasil). Terminado o preparo dos canais radiculares, realizou-se a impermeabilização das raízes, 
cuidando para que os agentes impermeabilizadores fossem aplicados respeitando-se 0,5mm ao redor do forame apical. Para a impermeabilização, primeiramente, foi aplicada uma camada de araldite de presa rápida (Brascola Ltda, São Paulo, Brasil) e, após a sua polimerização, foram aplicadas duas camadas de esmalte para unhas (Niasi SA, São Paulo, Brasil) (Figura 3).
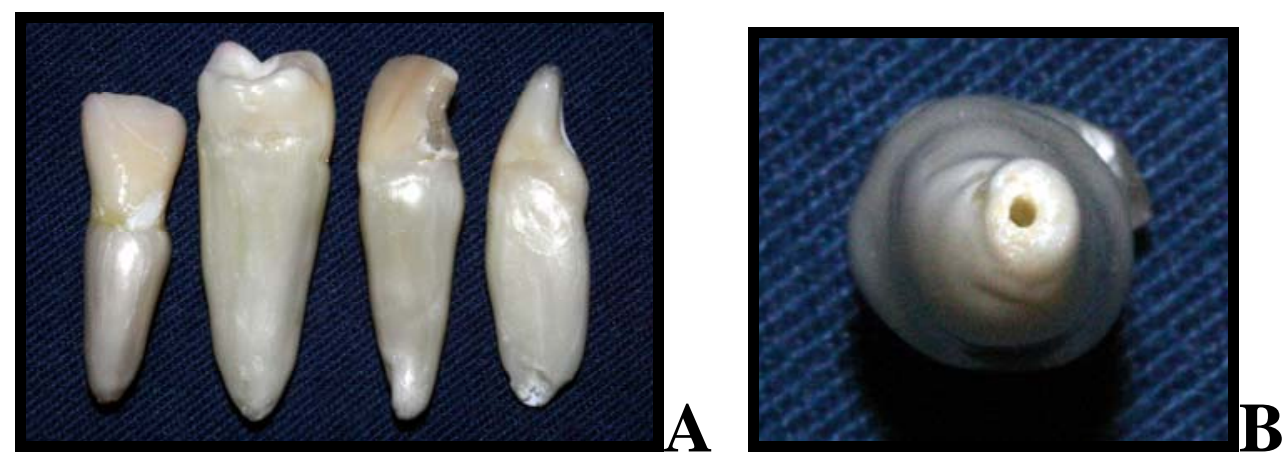

Figura 3 A e B; A: Impermeabilização das raízes com araldite e esmalte para unhas; B: Forame sem impermeabilização.

Em seguida, os canais foram preenchidos com EDTA (ácido etilenodiaminotetracético) a 17\% (Biodinâmica Química e Farmacêutica Ltda, Ibiporã, Brasil), por três minutos. Após esse tempo, o EDTA foi neutralizado por meio de uma irrigação com 5mL de soro fisiológico (Laboratório Tayuyna, Nova Odessa, Brasil).

Na seqüência, os dentes foram divididos em 4 grupos de 30 espécimes cada, de acordo com os materiais utilizados na confecção dos tampões apicais (Quadro 1), ou seja:

Grupo 1: tampão apical feito com pasta L \& C (controle);

Grupo 2: tampão apical com o cimento MTA-Angelus ${ }^{\circledR}$ cinza;

Grupo 3: tampão apical com o cimento $\mathrm{CPM}^{\circledR}$;

Grupo 4: tampão apical com o cimento MBPc.

Quadro 1. Grupos e número de espécimes, em função dos materiais utilizados.

\begin{tabular}{|c|c|c|}
\hline GRUPO & MATERIAL & $\begin{array}{c}\text { NÚMERO DE } \\
\text { ESPÉCIMES }\end{array}$ \\
\hline 1 & Pasta L \& C $^{\circledR}$ & 30 \\
\hline 2 & MTA-Angelus $^{\circledR}$ cinza & 30 \\
\hline 3 & CPM $^{\circledR}$ & 30 \\
\hline 4 & MBPc & 30 \\
\hline
\end{tabular}


Após a secagem dos canais com cones de papel absorvente (Tanariman Industrial Ltda, Manacapuru, Brasil) foram confeccionados os tampões apicais. A extensão dos tampões foi a mesma para todos os materiais, ou seja, 5mm. Todos os materiais foram manipulados seguindo-se as instruções dos fabricantes/idealizador.

A confecção do tampão com a pasta L \& C (Dentsply Indústria e Comércio Ltda, Petrópolis, Brasil) diferiu da confecção com os demais materiais (cimentos). Inicialmente foi feita uma pasta, de acordo com as instruções de uso e, com auxílio de uma espiral Lentulo (Dentsply-Maillefer Instuments SA, Ballaigues, Suíça), a mesma foi levada ao canal radicular de forma a preenchê-lo completamente. Essa pasta permaneceu preenchendo o canal até momentos antes da fase seguinte do experimento, isto é, a obturação definitiva do canal radicular. Durante esse período os dentes permaneceram armazenados em estufa a $37^{\circ} \mathrm{C}$, em ambiente com $100 \%$ de umidade relativa.

O MTA-Angelus ${ }^{\circledR}$ cinza (Angelus Soluções Odontológicas, Londrina, Brasil) foi manipulado e, então, aplicado no canal radicular utilizando-se uma espiral Lentulo em baixa rotação, que era levada ao canal até 3mm aquém do forame apical. A compactação do material foi feita com uma lima tipo K número 90 com parte da mesma envolta em algodão (Figura 4). Para a retirada do excesso do material das paredes do canal foi utilizada uma lima tipo $\mathrm{K}$ número 70 com parte envolta em algodão umedecido. Nos casos em que ocorreu extravasamento do material, este foi removido até que o tampão ficasse rente ao forame apical. 

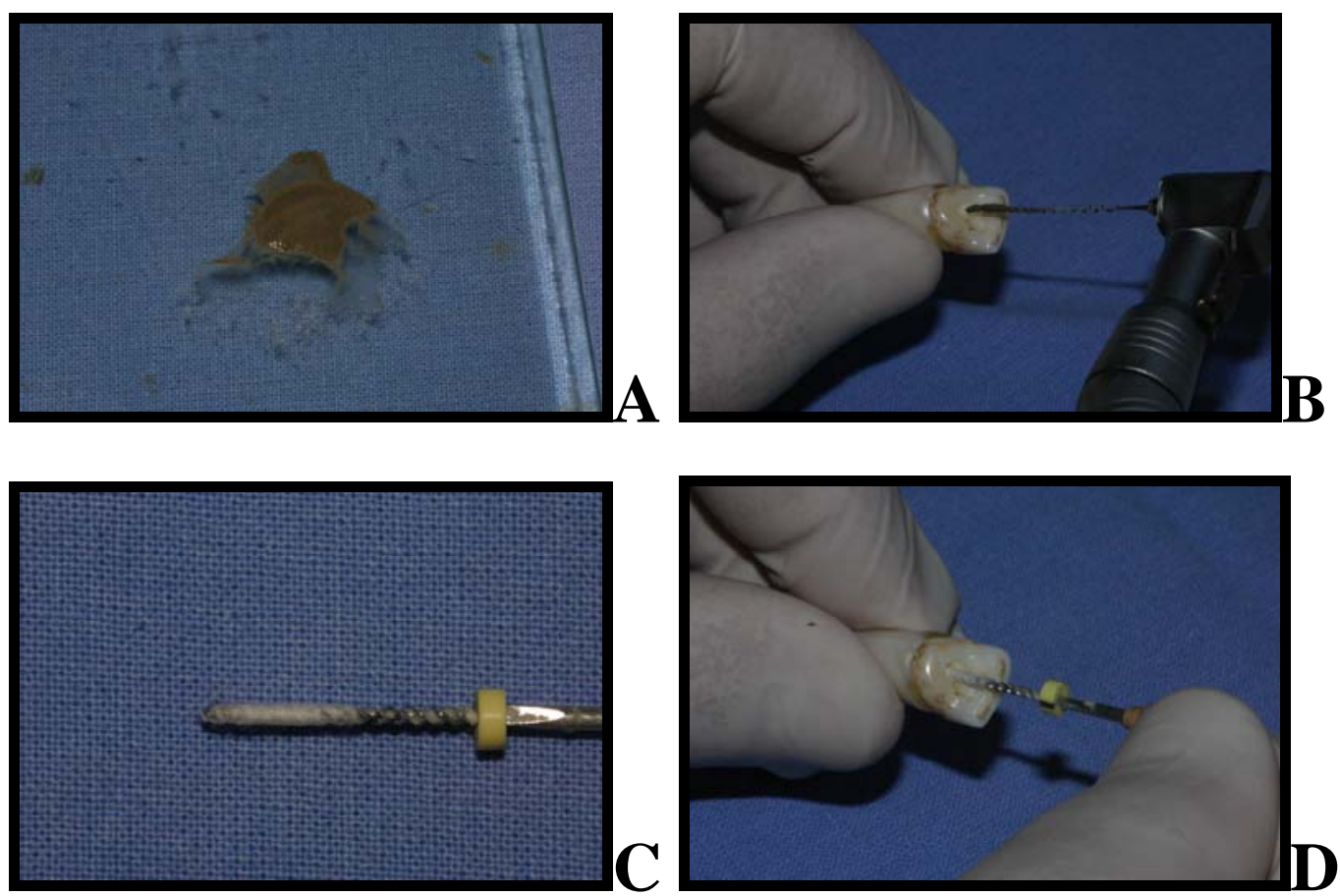

Figura 4 A - D; A: MTA-Angelus ${ }^{\circledR}$ cinza após a manipulação; B: Colocação do cimento no canal radicular com espiral Lentulo; C: Parte da lima envolta em algodão; D: Compactação do cimento.

O CPM ${ }^{\circledR}$ (Egeo S.R.L., Buenos Aires, Argentina) também foi manipulado de acordo com as instruções do fabricante e levado ao canal radicular, também, por meio de uma espiral Lentulo. A compactação do $\mathrm{CPM}^{\circledR}$ foi realizada de forma semelhante à do MTA e, quando houve extravasamento, o excesso também foi removido.

Com relação ao MBPc, o mesmo foi utilizado de acordo com o seu idealizador, que consistiu na mistura de quatro partes de pasta base e uma parte de pasta catalisadora. Após a homogeneização das pastas, obteve-se um cimento com consistência de “massa de vidraceiro" que foi levado ao canal radicular por meio de uma lima tipo K número 70. Para tal, uma porção do cimento era colocada sobre uma placa de vidro e, com uma espátula número 24 apoiada sobre o cimento, eram realizados movimentos tais, fazendo com que a porção fosse tomando a forma de um "cilindro". Na seqüência, prendeu-se um pequeno “cilindro” na ponta da lima tipo K e esta foi introduzida no canal radicular. Ao atingir o comprimento desejado, rotacionou-se a lima no sentido anti-horário para que o "cilindro" de cimento fosse depositado no terço apical do canal. A compactação foi feita com compactadores manuais do tipo Paiva e 
limas tipo K números 80 e 90, e quando houve extravasamento o excesso também foi removido até que o tampão ficasse rente ao forame apical (Figura 5). Cuidou-se, sempre, para que durante a remoção, o cimento não fosse comprimido contra o ápice radicular.
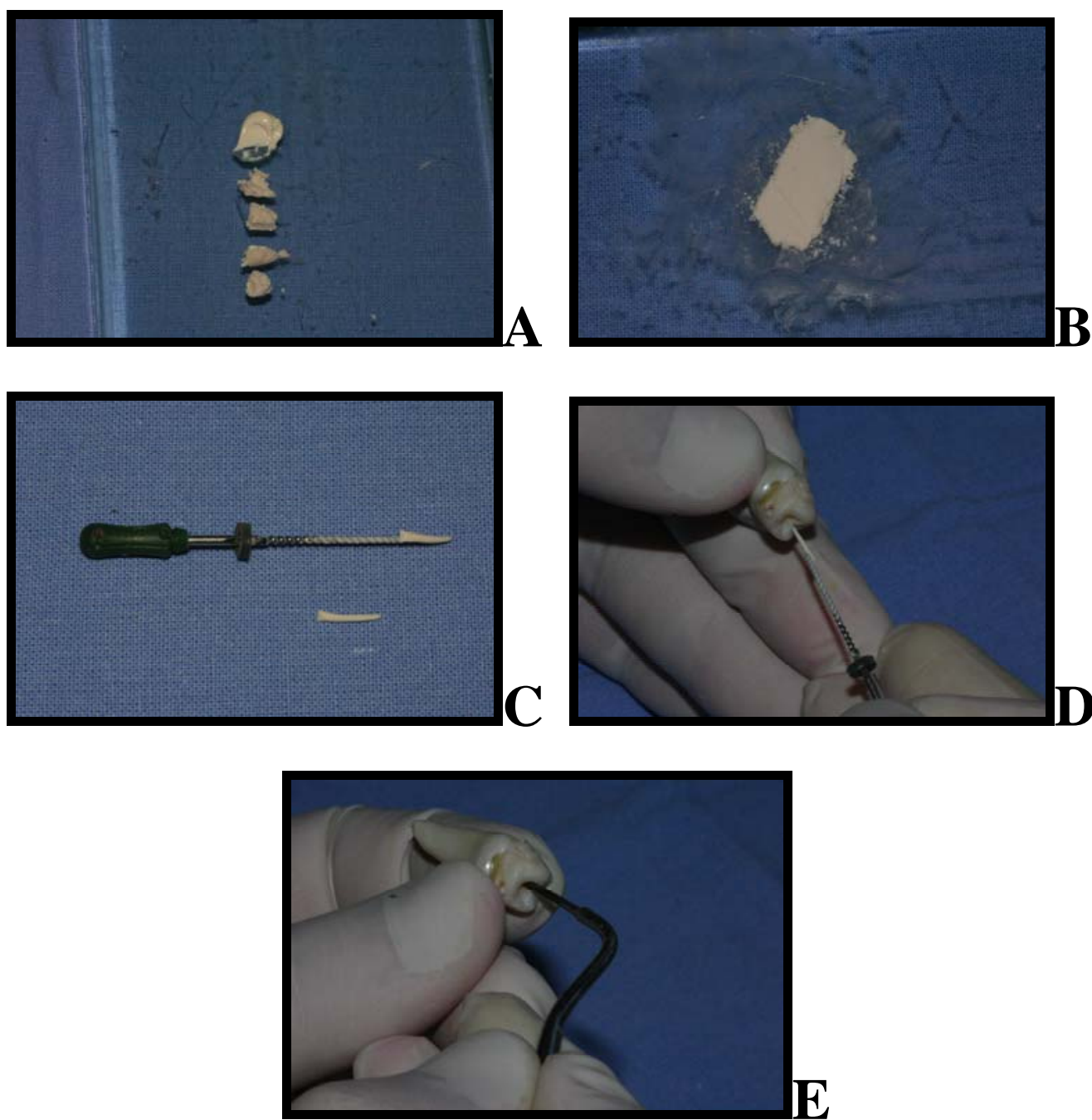

Figura 5 A - E; A: Proporcionamento do cimento MBPc; B: Homogeneização do cimento; C: Confecção dos “cilindros” de cimento; D: Inserção no canal radicular; E: Compactação com compactador manual.

Para a confirmação das medidas e das posições dos tampões foram realizadas radiografias de todos os dentes de todos os grupos envolvidos.

Após a confecção dos tampões nos dentes dos grupos 2, 3 e 4, as porções remanescentes dos canais radiculares foram preenchidas com uma pasta aquosa de hidróxido de cálcio (Odontopharma Indústria e Comércio Ltda, Porto Alegre, Brasil) e soro fisiológico, permanecendo até o momento da obturação dos canais. Todos os 120 
dentes permaneceram armazenados em estufa à $37^{\circ} \mathrm{C}$, em ambiente com $100 \%$ de umidade relativa por, pelo menos, 48 horas, para, então, realizar-se a obturação dos canais.

Imediatamente antes da obturação a pasta de hidróxido de cálcio dos canais dos dentes dos grupos 2, 3 e 4 foi removida por meio de irrigação com soro fisiológico e limas tipo K número 100.

Já, nos dentes do grupo 1 (pasta L \& C), a pasta foi retirada parcialmente, em pequenas porções, até que restassem apenas os $5 \mathrm{~mm}$ finais (tampão apical). Antes da obturação cada grupo foi dividido em 3 subgrupos, em função das técnicas obturadoras utilizadas: técnica da condensação lateral, técnica híbrida de Tagger e técnica de injeção de guta-percha plastificada, utilizando-se o sistema Ultrafil (Hygenic, Coltène Whaledent Inc., New Jersey, Estados Unidos da América) de acordo com o Quadro 2.

Quadro 2. Subgrupos e número de espécimes, em função das técnicas obturadoras utilizadas.

\begin{tabular}{|c|c|c|}
\hline SUBGRUPOS & $\begin{array}{c}\text { TÉCNICA } \\
\text { OBTURADORA }\end{array}$ & $\begin{array}{l}\text { NÚMERO DE } \\
\text { ESPÉCIMES }\end{array}$ \\
\hline 1.1 Pasta L \& C & Condensação lateral & 10 \\
\hline 1.2 Pasta L \& C & Híbrida de Tagger & 10 \\
\hline 1.3 Pasta L \& C & Ultrafil & 10 \\
\hline 2.1 MTA-Angelus ${ }^{\circledR}$ cinza & Condensação lateral & 10 \\
\hline 2.2 MTA-Angelus ${ }^{\circledR}$ cinza & Híbrida de Tagger & 10 \\
\hline 2.3 MTA-Angelus $\left.{ }^{(}\right)$cinza & Ultrafil & 10 \\
\hline $3.1 \mathrm{CPM}^{\circledR}$ & Condensação lateral & 10 \\
\hline $3.2 \mathrm{CPM}^{\circledR}$ & Híbrida de Tagger & 10 \\
\hline $3.3 \mathrm{CPM}^{(\circledR)}$ & Ultrafil & 10 \\
\hline 4.1 MBPC & Condensação lateral & 10 \\
\hline 4.2 MBPc & Híbrida de Tagger & 10 \\
\hline $4.3 \mathrm{MBPc}$ & Ultrafil & 10 \\
\hline
\end{tabular}

O cimento utilizado para a obturação dos canais foi o Sealer 26 (Dentsply Indústria e Comércio Ltda, Petrópolis, Brasil).

Para a realização da técnica da condensação lateral, foram utilizados cones principais de guta-percha número 80 (Tanariman Industrial Ltda, Manacapuru, Brasil) e cones acessórios R7 (Tanariman Industrial Ltda, Manacapuru, Brasil). Os cones principais tiveram as pontas cortadas, até que os mesmos ficassem adaptados às paredes dos canais, apoiados nos tampões apicais. O cone principal foi levado ao canal radicular 
juntamente com o cimento endodôntico e, utilizando-se uma lima tipo K número 30 (Dentsply-Maillefer Instuments SA, Ballaigues, Suíça) para abrir espaços, foram inseridos cerca de 5 a 6 cones acessórios no canal. Os cones foram cortados com um condensador de Paiva aquecido, e a obturação foi condensada verticalmente, com outro condensador.

Para a técnica híbrida de Tagger, os procedimentos iniciais foram os mesmos da técnica da condensação lateral. Porém, foram inseridos cerca de 3 a 4 cones acessórios no canal radicular. Um compactador de guta-percha número 80 (DentsplyMaillefer Instuments SA, Ballaigues, Suíça) foi selecionado. O compactador, acoplado ao contra-ângulo, foi introduzido no canal até encontrar-se resistência, acionando-se, então, o contra-ângulo, com giro no sentido horário. Após a plastificação da gutapercha, o compactador foi levado em direção apical até 4mm do tampão apical, permanecendo, aí, por 1 segundo, sendo, então, retirado, ainda acionado. Com um condensador manual, a guta-percha plastificada foi condensada, e o excesso desse material foi retirado com um condensador aquecido.

A técnica de injeção de guta-percha utilizou o sistema Ultrafil. Este sistema é composto por agulhas carregadas com guta-percha, uma seringa injetora e um plastificador. Existem três tipos de guta-percha, quanto à viscosidade: a regular set (baixa viscosidade), com tempo de endurecimento de 30 minutos; a firm set (viscosidade moderada), que endurece após 4 minutos, e a endoset (alta viscosidade), com tempo de endurecimento de 2 minutos. A guta-percha utilizada para a obturação dos canais radiculares foi a firm set. A agulha foi acoplada à seringa injetora, e o conjunto, levado ao plastificador, que atingiu a temperatura de $70^{\circ} \mathrm{C}$. O cimento endodôntico foi levado ao canal radicular com uma lima tipo $K$ antes da injeção da guta-percha. Após a plastificação da guta-percha, a mesma foi injetada no canal radicular com o acionamento do êmbolo da seringa, até o preenchimento de toda a porção remanescente do canal. Terminado o preenchimento, foi realizada a condensação vertical do material obturador.

Realizadas as obturações, as coroas dos dentes foram impermeabilizadas pela imersão das mesmas em cera derretida e, sobre esta, foram aplicadas duas camadas de esmalte para unhas. Os 10 dentes de cada subgrupo, devidamente identificados, tiveram suas coroas fixadas em discos de cera utilidade (Asfer Indústria Química Ltda, São Caetano do Sul, Brasil) e foram colocados em recipientes plásticos, deixando-se os ápices livres e voltados para cima. A solução corante de Rodamina B (Labsynth 
Produtos para Laboratórios Ltda, Araçatuba, Brasil) a 0,2\%, pH 7,0 foi colocada nos recipientes até recobrir completamente os ápices de todos os dentes (Figura 6).
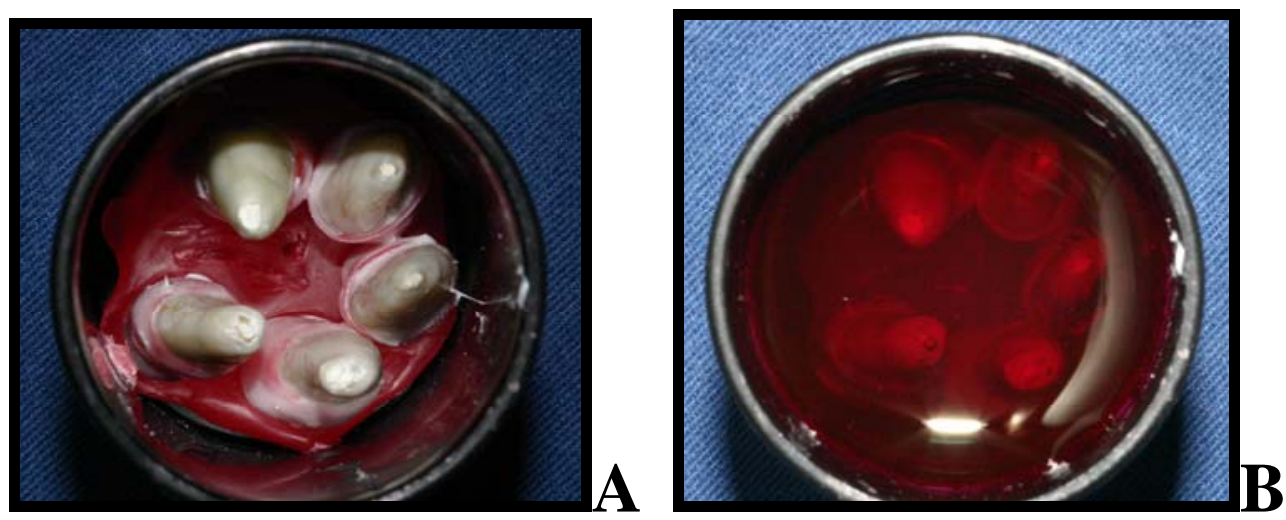

Figura 6 A e B; A: Dentes fixados em cera utilidade com os ápices voltados para cima; B: Rodamina B a 0,2\% recobrindo completamente os ápices.

Os recipientes foram levados à estufa a $37^{\circ} \mathrm{C}$, onde permaneceram por 48 horas. Após este período os dentes foram retirados do corante, lavados em água corrente por 24 horas, a impermeabilização foi, então, removida com uma espátula LeCron, os dentes escovados e, novamente, lavados por mais 12 horas.

Após a secagem dos dentes, estes foram desgastados longitudinalmente, na face mesial ou na distal, utilizando-se discos de carburundum, de modo a expor o tampão apical e a obturação.

A seguir, foram realizadas fotografias de todos os espécimes. Estes, em conjuntos de 5 elementos, foram apoiados sobre uma tira de cera utilidade e fotografados com uma máquina fotográfica digital Canon EOS Rebel, acoplada a uma estativa. Junto aos dentes, também, foi fotografado um segmento de régua plástica milimetrada (Figura 7). 


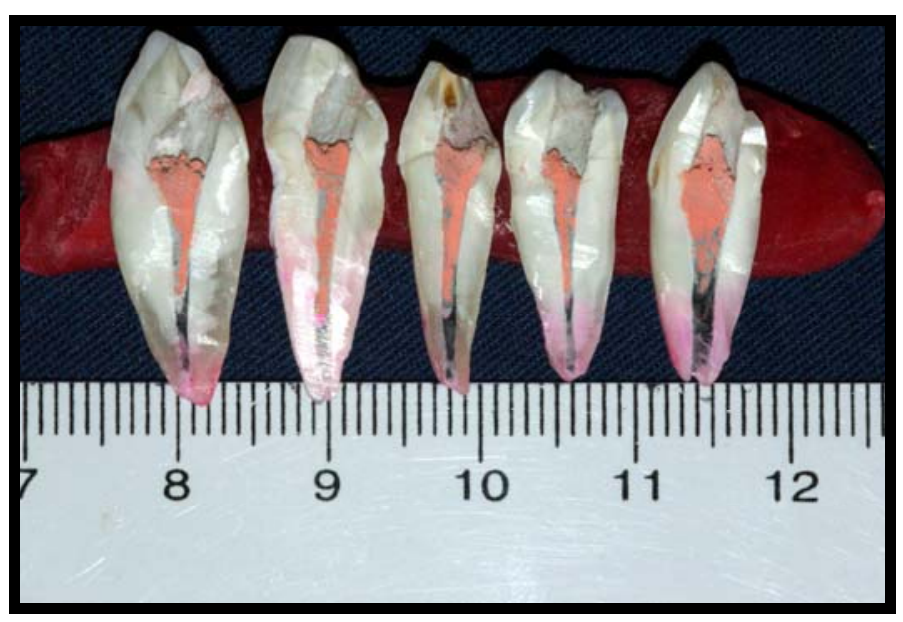

Figura 7: Fotografia dos dentes e do segmento da régua milimetrada para análise da infiltração de Rodamina B.

Para a análise da capacidade de selamento dos materiais testados, as fotografias foram levadas ao software Image Tool 3.0. A imagem do segmento da régua serviu de parâmetro para as medições. Primeiramente, foi feita a calibração das medidas, onde um traço era feito sobre a régua, de modo a se obter quantos "pixels" representavam $1 \mathrm{~mm}$. Obtida esta medida, a mensuração da infiltração da solução de Rodamina B a 0,2\% foi feita de forma linear, considerando-se, como medida de infiltração, o traço de maior extensão do corante, na interface tampão apical-parede dentinária, desde a porção mais apical do material até a sua porção mais cervical. Ao se determinar a extensão da infiltração, os valores eram, automaticamente, transformados de “pixels” para milímetros (Figura 8). 


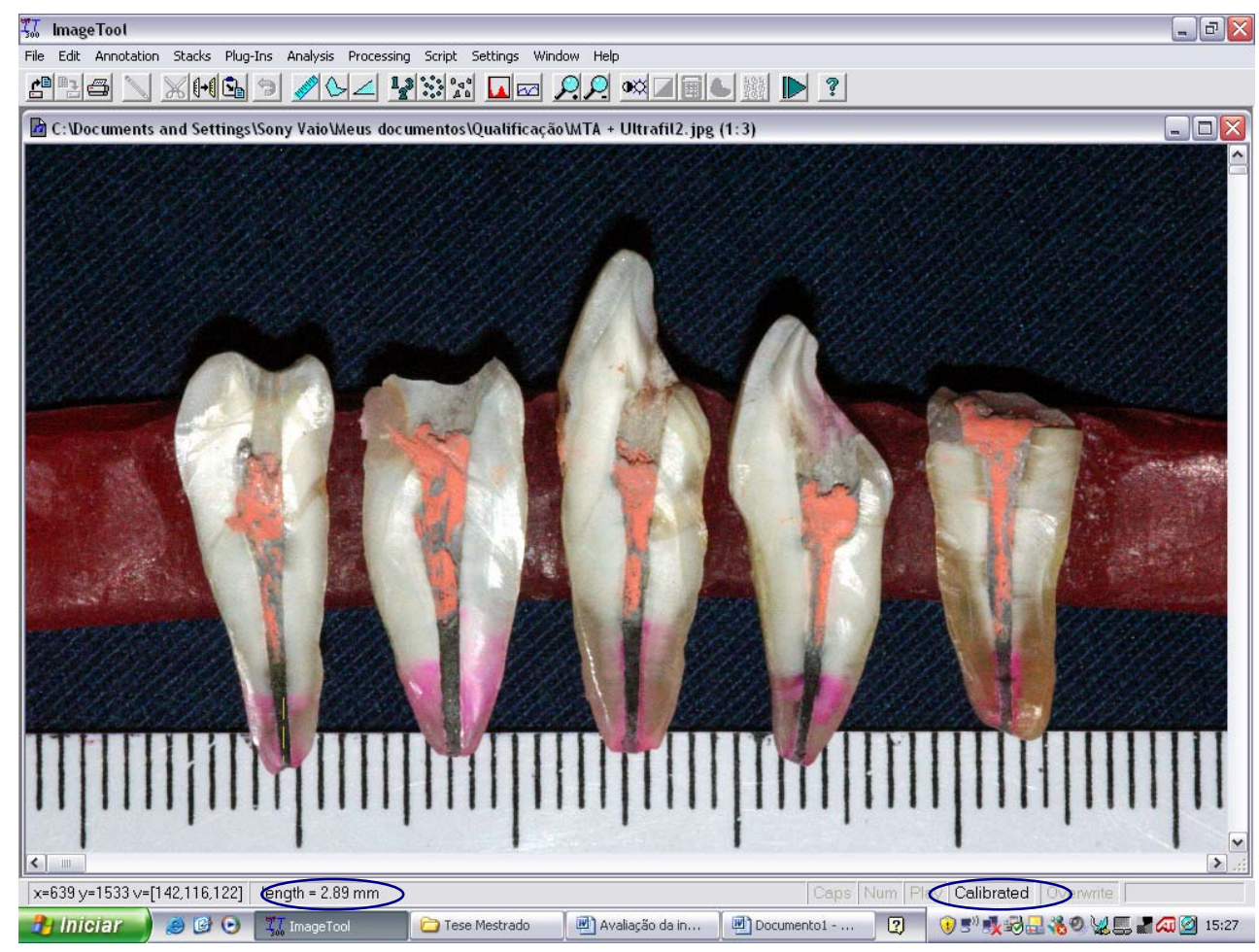

Figura 8: Medida da infiltração de Rodamina B feita no software Image Tool 3.0.

Três observadores, devidamente calibrados, realizaram a mensuração da infiltração nas fotografias, atuando de forma independente um do outro.

Os resultados obtidos foram tabulados, convertidos para porcentagem e submetidos ao teste estatístico não-paramétrico de Kruskal-Wallis, para a determinação de possíveis diferenças entre os materiais testados e, ao teste de Dunn, para a confirmação da significância da diferença entre os grupos.

\subsection{Preparo dos espécimes para microscopia eletrônica de varredura}

\subsubsection{Manobras prévias e montagem}

Para a realização do teste de adaptação marginal às paredes dentinárias dos tampões apicais foram utilizados os mesmos dentes submetidos ao teste de infiltração de Rodamina B a 0,2\%, com exceção dos dentes do grupo 1 (pasta L \& C), que não foram submetidos a este teste. Assim, os 90 espécimes (hemipartes) dos grupos 2, 3 e 4 (relativos aos cimentos MTA-Angelus ${ }^{\circledR}$ cinza, $\mathrm{CPM}^{\circledR}$ e MBPc, respectivamente), foram seccionados transversalmente a $7 \mathrm{~mm}$ do ápice (Figura 9), obtendo-se segmentos que 
continham os tampões (5mm) e parte da obturação, guta-percha e cimento endodôntico $(2 \mathrm{~mm})$.

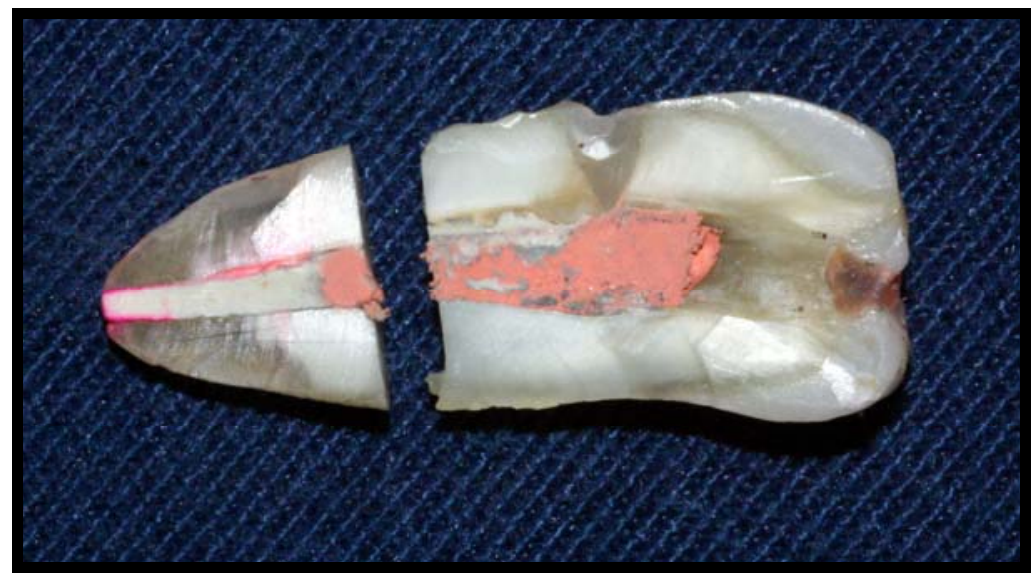

Figura 9: Hemiparte do dente seccionada transversalmente a 7mm do ápice.

Em seguida, para a realização da metalização, esses segmentos foram fixados, com esmalte para unhas, em bases cilíndricas de metal (“stub”), de modo que a parte a ser analisada no M.E.V. ficasse voltada para o observador (Figura 10).

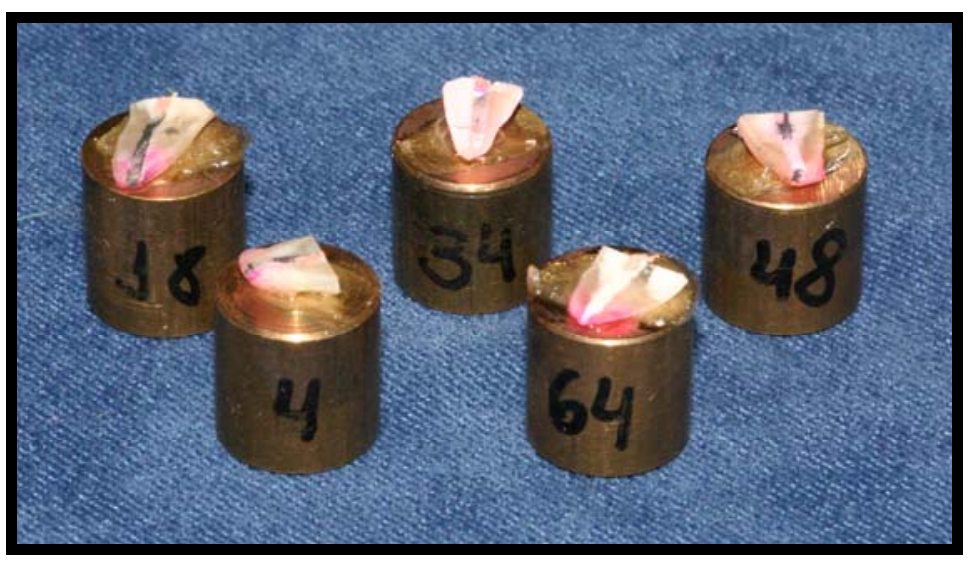

Figura 10: Fixação dos segmentos apicais para metalização.

\subsubsection{Metalização}

O conjunto foi levado ao aparelho metalizador DENTON VACUUM DESK IV, e os segmentos foram, então, recobertos com uma camada de ouro de 30 a 40nm de espessura (Figura 11). 


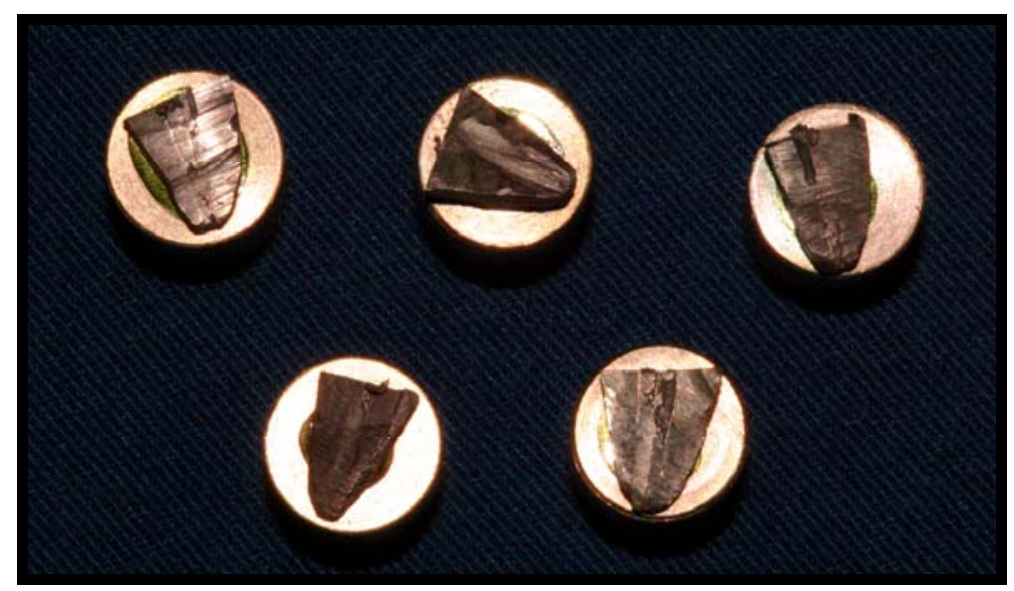

Figura 11: Segmentos apicais metalizados.

\subsubsection{Fotomicrografias em microscopia eletrônica de varredura e análise da adaptação dos materiais às paredes dentinárias}

Os segmentos, já metalizados, foram levados ao microscópio eletrônico de varredura (M.E.V.), modelo JEOL JSM-T220 A, operando com 10kV, para a realização das fotomicrografias que foram obtidas com uma máquina fotográfica MAMIYA 50A MRH, acoplada ao próprio microscópio. Foram utilizados filmes Neopan 100, ACROS (Fuji Photo Film Co. Ltda, Tóquio, Japão), preto e branco (Figura 12), obtendo-se fotomicrografias com aumentos de 35X e 150X.

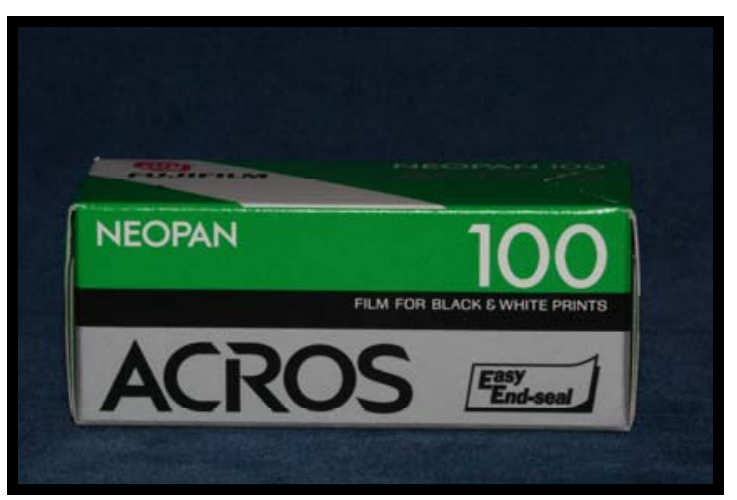

Figura 12: Filme Neopan 100, ACROS, preto e branco.

Com o aumento de 35X conseguiu-se uma visão panorâmica da adaptação do tampão apical às paredes dentinárias, enquanto que o aumento de 150X permitiu observar os locais em que havia espaços entre o tampão e as paredes dentinárias ou, então, a perfeita adaptação entre eles (Figuras 13, 14 e 15). 

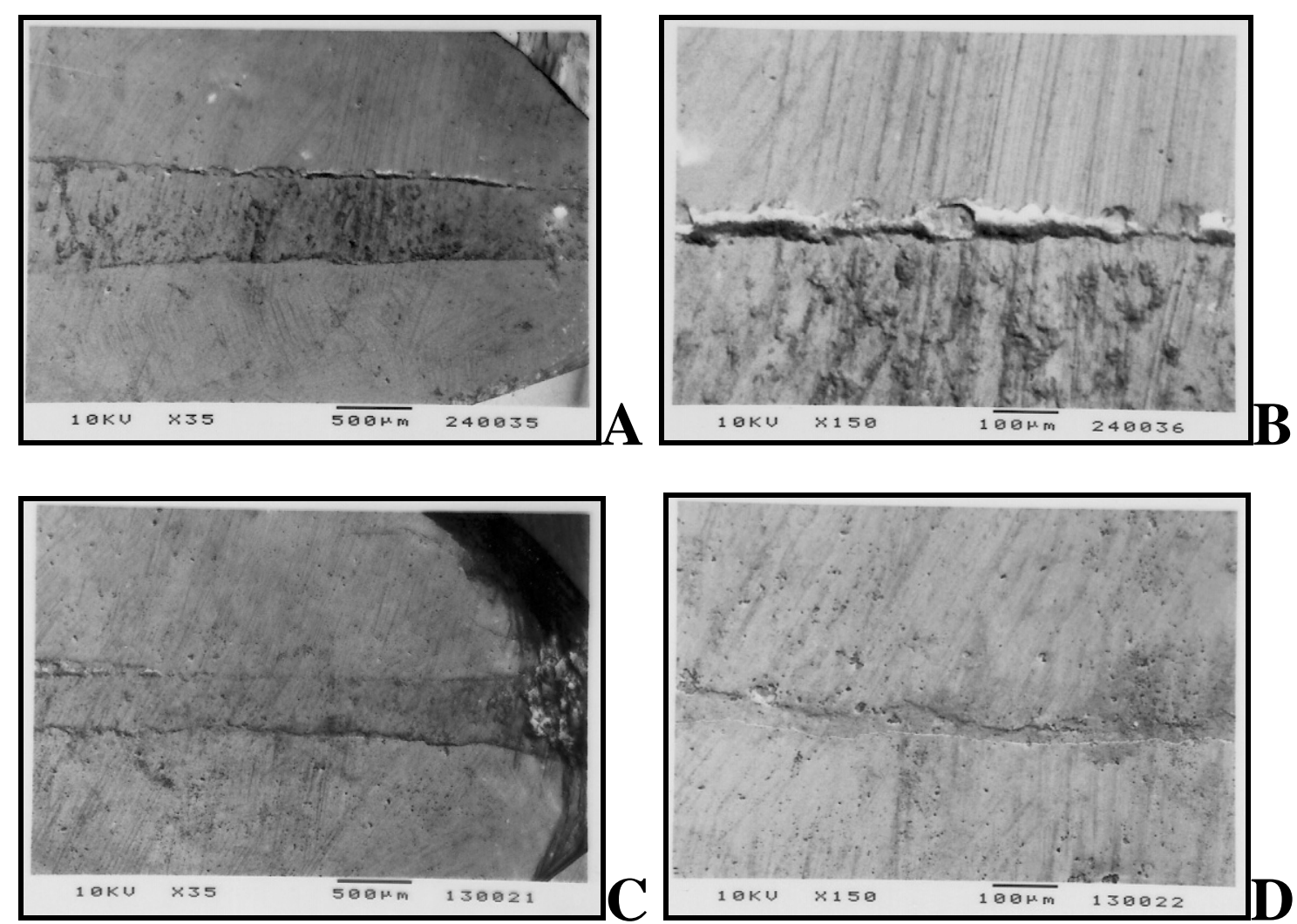

Figura 13 A - D: A: Tampão apical feito com MTA-Angelus ${ }^{\circledR}$ cinza; B: Fotomicrografia mostrando a desadaptação do tampão em relação à parede dentinária; C: Tampão apical feito com MTA-Angelus ${ }^{\circledR}$ cinza; D: Fotomicrografia mostrando a adaptação do tampão à parede dentinária. 

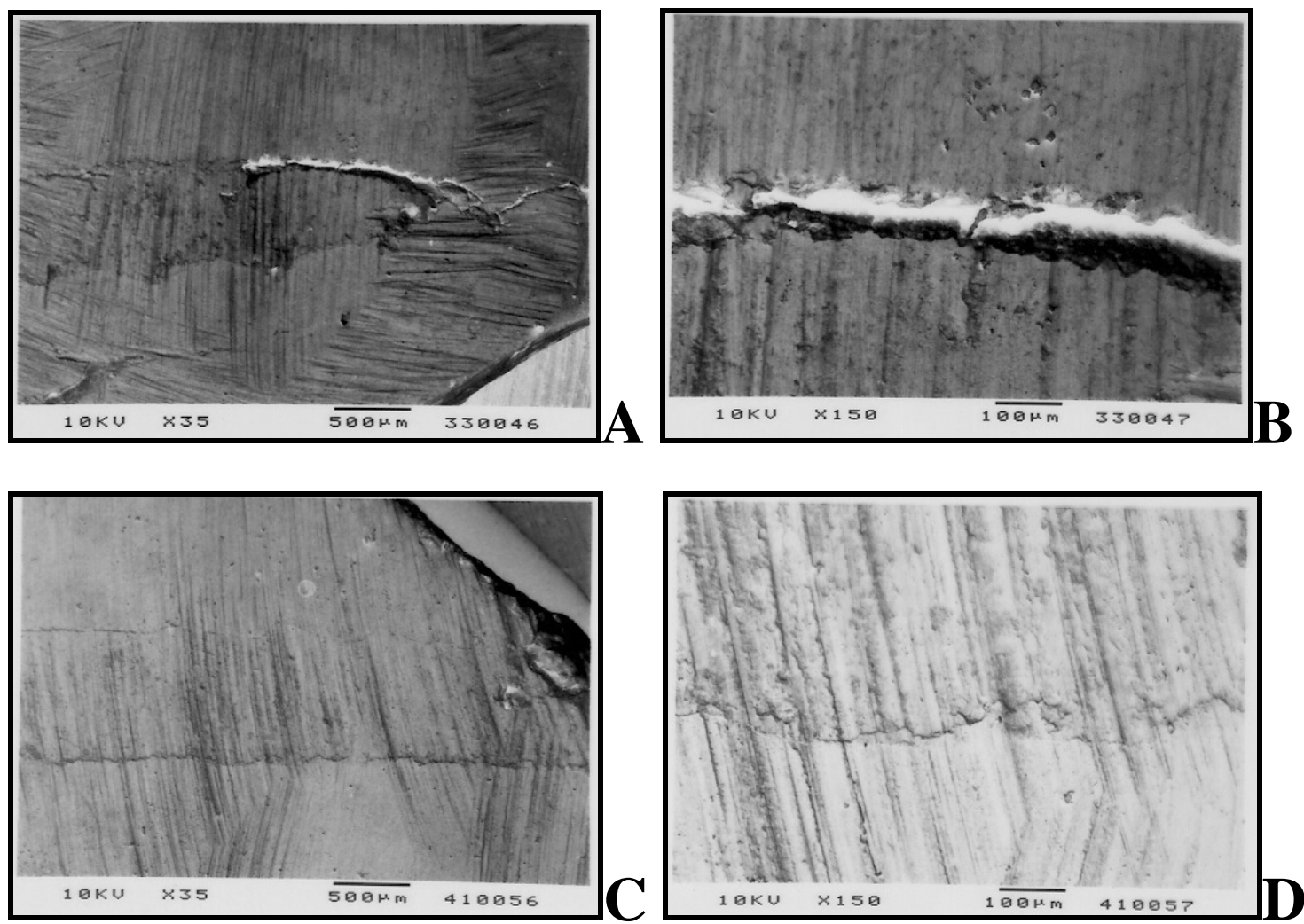

Figura 14 A - D: A: Tampão apical feito com $\mathrm{CPM}^{\circledR}$; B: Fotomicrografia mostrando a desadaptação do tampão em relação à parede dentinária; C: Tampão apical feito com $\mathrm{CPM}^{\circledR}$; D: Fotomicrografia mostrando a adaptação do tampão à parede dentinária. 

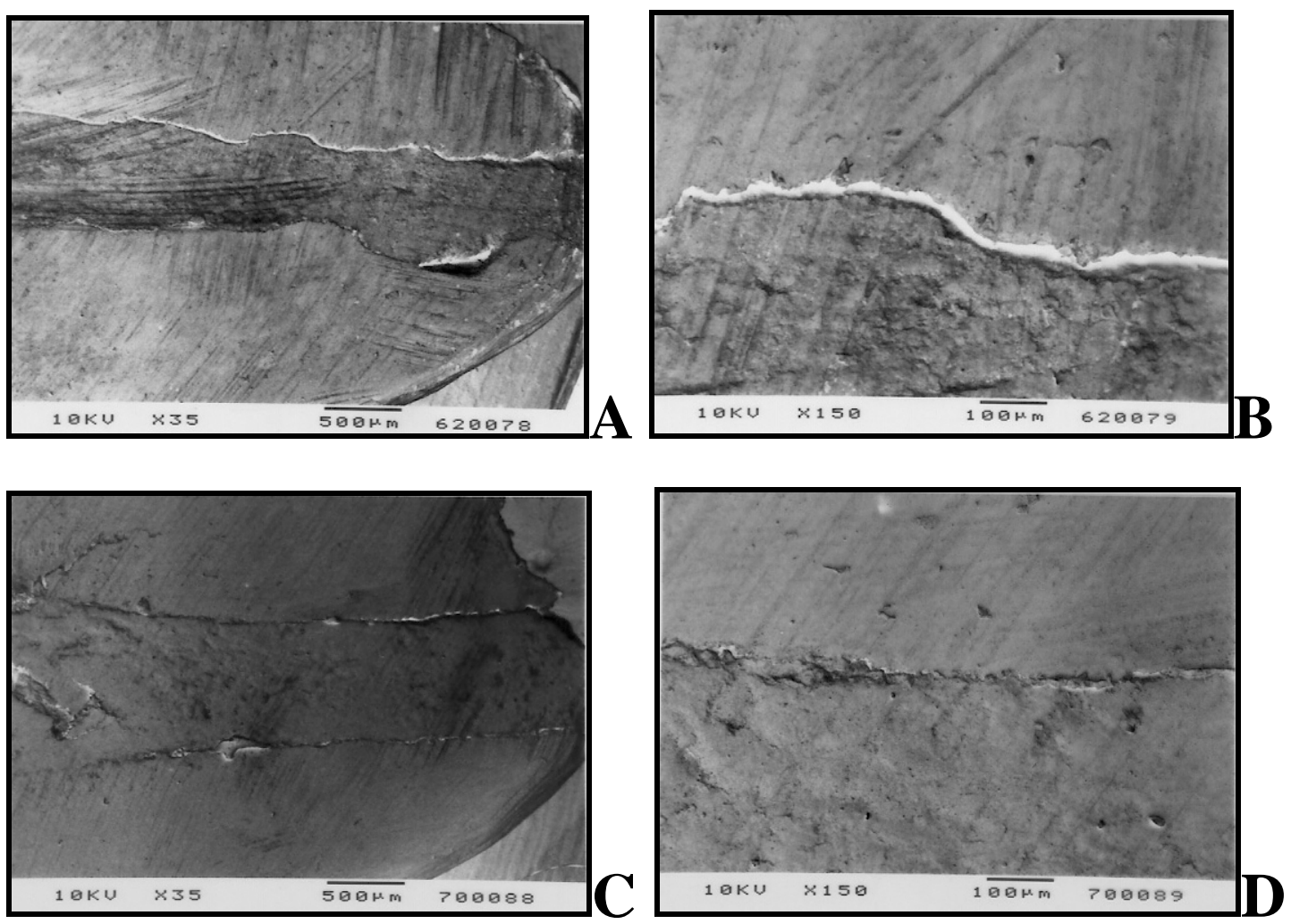

Figura 15 A - D: A: Tampão apical feito com MBPc; B: Fotomicrografia mostrando a desadaptação do tampão em relação à parede dentinária; C: Tampão apical feito com MBPc; D: Fotomicrografia mostrando a adaptação do tampão à parede dentinária.

Para a análise da adaptação marginal dos cimentos testados, as fotomicrografias com aumento de 35X foram levadas ao software Image Tool 3.0 e a mensuração da desadaptação foi feita de forma linear, medindo-se, em micrometros, a extensão da mesma. A medida foi realizada da seguinte maneira: como as fotomicrografias com aumento de 35X apresentam uma referência (traço) com 500 $\mu$ m de extensão, a mesma foi utilizada para se realizar a calibração das medidas, determinando quantos “pixels” corresponderiam à 500 $\mu$ m. Após a obtenção dessa medida, um traço foi feito ao longo da desadaptação, quando esta existia, e os valores eram convertidos, automaticamente, de "pixels" para micrometros, determinando a extensão linear da desadaptação (Figura 16).

Três observadores, devidamente calibrados, realizaram a leitura das fotomicrografias, atuando de forma independente um do outro.

Os resultados obtidos foram tabulados e submetidos ao teste estatístico nãoparamétrico de Kruskal-Wallis, para a determinação de possíveis diferenças entre os 
materiais testados e, ao teste de Dunn, para a confirmação da significância da diferença entre os grupos.

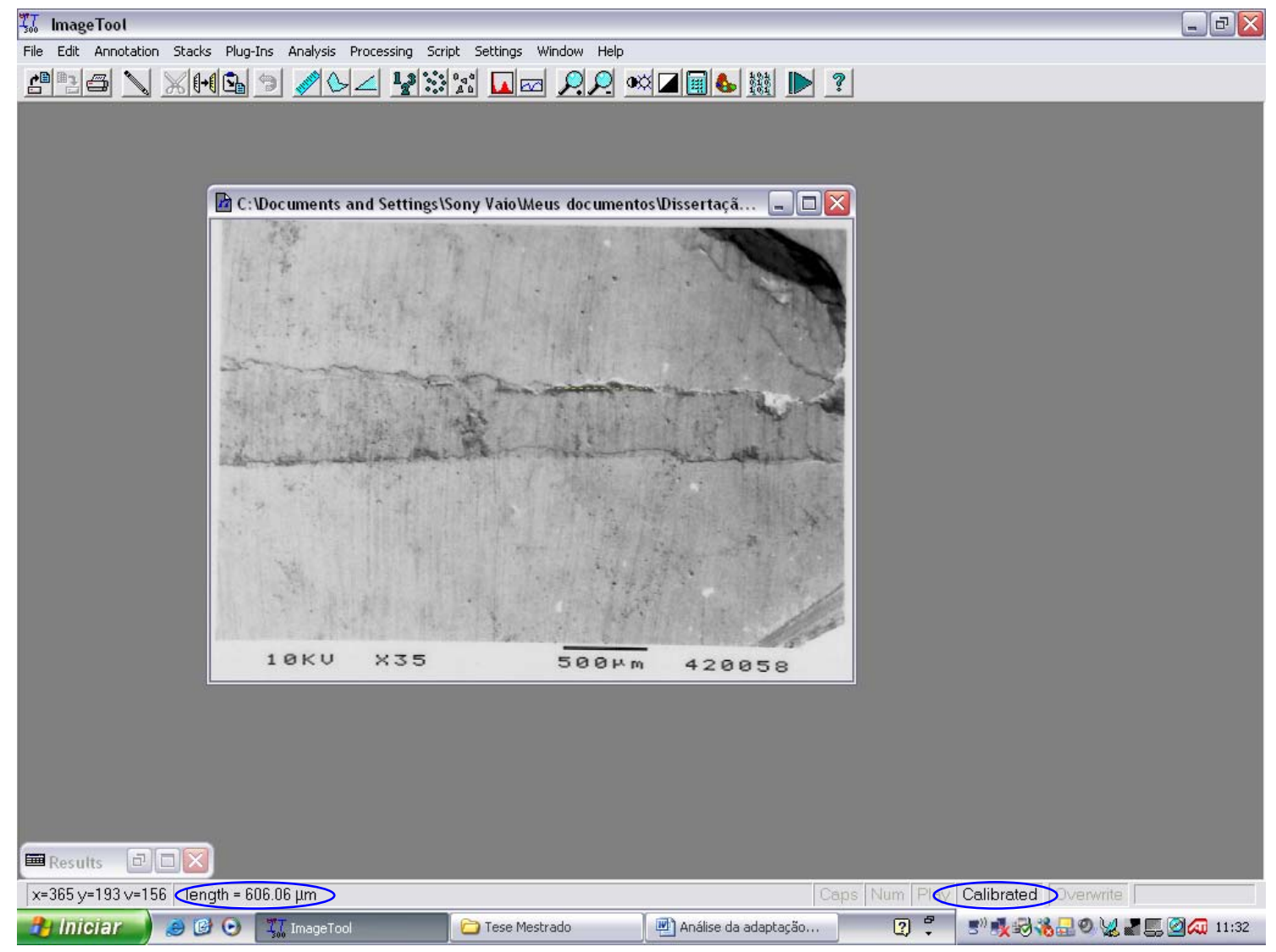

Figura 16: Medida da desadaptação marginal do tampão apical.

\subsection{Materiais utilizados}

\subsubsection{Pasta L \& C}

Pasta de hidróxido de cálcio com veículo oleoso. Apresenta embalagem contendo um frasco com 12 gramas de pó e um frasco com 10 mililitros de líquido.

A sua fórmula apresenta a seguinte composição:

Pó: Hidróxido de cálcio, Carbonato de bismuto, Breu.

Líquido: Óleo de oliva purificado. 


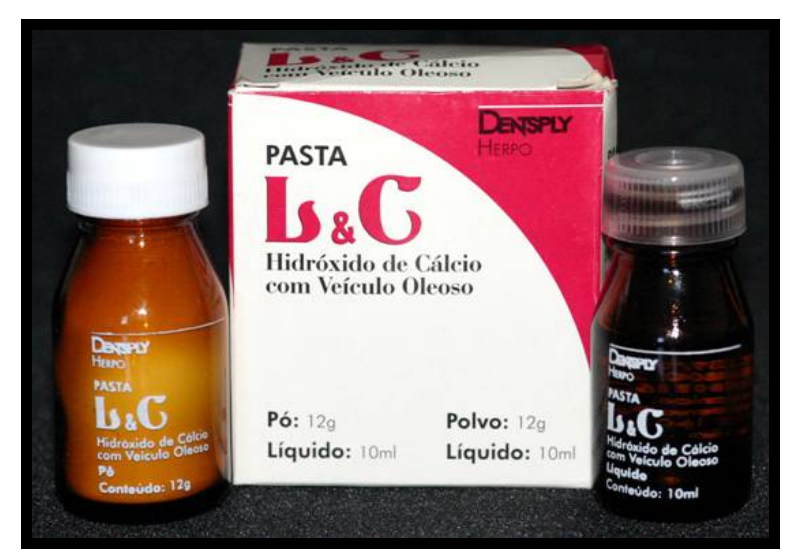

Figura 17: Pasta L \& C.

Para a utilização da pasta L \& C, foram seguidas as instruções do fabricante, que implicam na colocação de duas ou três gotas do líquido em uma placa de vidro e, com uma espátula, vai-se incorporando o pó ao líquido, espalhando-se até se conseguir uma consistência cremosa e adesiva.

\subsubsection{Cimento MTA - Angelus ${ }^{\circledR}$ cinza}

Sua embalagem é composta por um frasco contendo 2 gramas de pó e um frasco com 3 mililitros de água destilada. Segundo o fabricante, o tempo de presa inicial é de, aproximadamente, 10 minutos, e o tempo final é de 15 minutos.

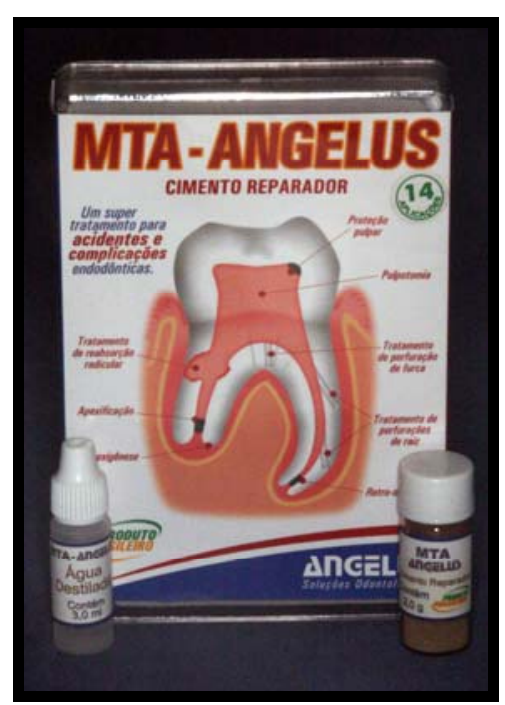

Figura 18: Cimento MTA-Angelus ${ }^{\circledR}$ cinza 
A sua fórmula apresenta a seguinte composição:

Pó: Dióxido de silício, Óxido de potássio, Alumina, Óxido de sódio, Óxido férrico, Trióxido de enxofre, Óxido de cálcio, Óxido de bismuto, Óxido de magnésio e resíduos insolúveis (sílica cristalina, óxido de cálcio e sulfato de potássio e sódio).

Líquido: Água destilada.

A proporção inicialmente utilizada nos experimentos foi a recomendada pelo fabricante, ou seja, uma medida do pó de MTA-Angelus para cada gota de água destilada. Porém, para se obter uma consistência mais pastosa, uma gota de água destilada era deixada de lado na placa de vidro e, durante a homogeneização dos componentes, a espátula era tocada nessa gota, e continuava-se a espatulação até o material atingir a consistência desejada.

\subsubsection{Cimento CPM ${ }^{\circledR}$}

Sua embalagem é composta por um frasco contendo 2 gramas de pó e um frasco com 5 mililitros de solução fisiológica estéril. O tempo de presa inicial, segundo o fabricante, é de, aproximadamente, 10 minutos e o tempo final é de 30 minutos.

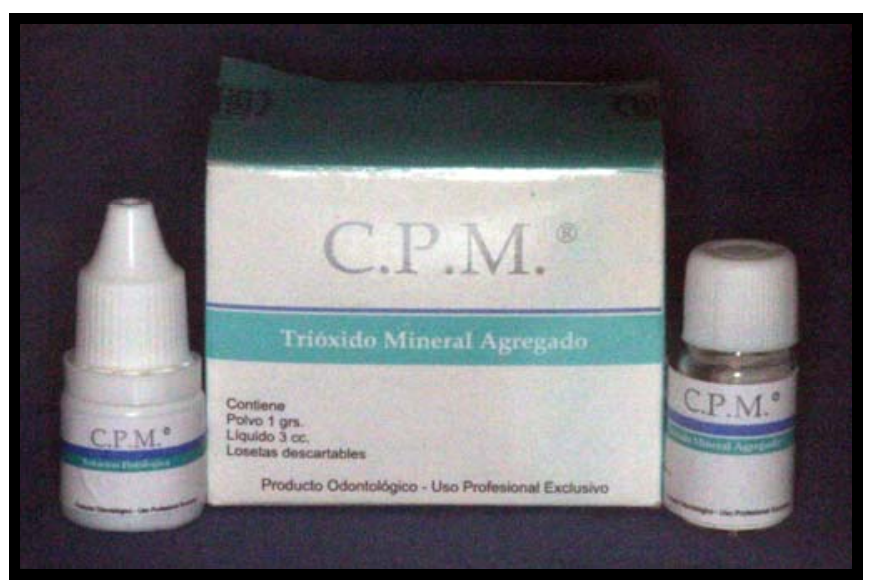

Figura 19: Cimento $\mathrm{CPM}^{\circledR}$

Sua fórmula apresenta a seguinte composição:

Pó: Dióxido de silício, Óxido de potássio, Alumina, Trióxido de enxofre, Óxido de cálcio, Óxido de bismuto, Óxido de magnésio; Carbonato de cálcio, Bióxido de silício, Trióxido de bismuto, Sulfato de bário e resíduos insolúveis (sílica cristalina, óxido de cálcio e sulfato de potássio e sódio).

Líquido: Solução fisiológica estéril. 
A proporção utilizada nos experimentos foi a recomendada pelo fabricante, ou seja, três partes de pó e uma gota de solução fisiológica. A homogeneização foi feita até se obter um cimento de consistência de massa de vidraceiro.

\subsubsection{Cimento MBPc}

Cimento experimental resinoso com hidróxido de cálcio, desenvolvido pelo Prof. Dr. Ivaldo Gomes de Moraes na disciplina de Endodontia da Faculdade de Odontologia de Bauru - USP. Apresenta embalagem contendo dois frascos, um a pasta base e outro a pasta catalisadora.

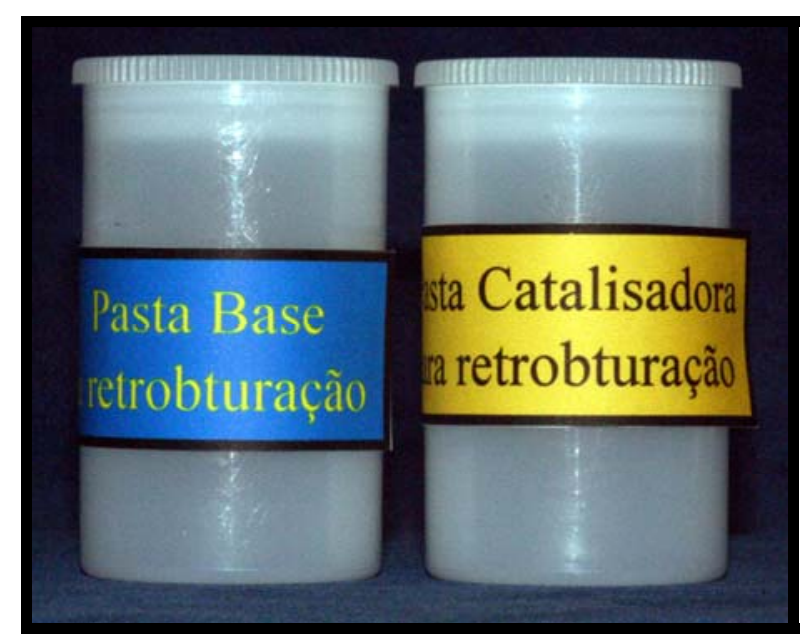

Figura 20: Cimento MBPc.

A sua fórmula apresenta a seguinte composição:

Pasta base: Hidróxido de cálcio; Subnitrato de bismuto; Resina epóxica.

Pasta catalisadora: Sulfato de bário; Subnitrato de bismuto; Endurecedor para resina epóxica; Poliol de poliuretana vegetal (mamona).

O tempo de presa inicial é de aproximadamente 2 horas, e o final, de 3 horas e 45 minutos. A proporção utilizada nos experimentos foi de quatro partes da pasta base para uma parte da pasta catalisadora, resultando em um cimento espesso, com consistência semelhante à massa de vidraceiro. 


\section{5 - RESULTADOS}




\section{RESULTADOS}

Todos os grupos apresentaram infiltração de Rodamina B a 0,2\%. A Tabela 1 apresenta as médias, calculadas em porcentagem, dos doze subgrupos utilizados para o teste de infiltração.

Tabela 1: Médias de infiltração de Rodamina B a 0,2\%, em porcentagem, considerando-se os materiais usados para a confecção dos tampões apicais e as técnicas obturadoras utilizadas.

\begin{tabular}{|c|c|c|}
\hline Materiais & Técnica Obturadora & Média de infiltração(\%) \\
\hline 1.1 Pasta L \& C & Condensação lateral & 98,40 \\
\hline 1.2 Pasta L \& C & Híbrida de Tagger & 98,40 \\
\hline 1.3 Pasta L \& C & Ultrafil & 98,60 \\
\hline Média & & 98,46 \\
\hline 2.1 MTA-Angelus ${ }^{\circledR}$ cinza & Condensação lateral & 65,40 \\
\hline 2.2 MTA-Angelus ${ }^{\circledR}$ cinza & Híbrida de Tagger & 59,80 \\
\hline 2.3 MTA-Angelus ${ }^{\circledR}$ cinza & Ultrafil & 78,00 \\
\hline Média & & 67,73 \\
\hline $3.1 \mathrm{CPM}^{\circledR}$ & Condensação lateral & 73,60 \\
\hline $3.2 \mathrm{CPM}^{(\mathbb{R}}$ & Híbrida de Tagger & 85,00 \\
\hline $3.3 \mathrm{CPM}^{\circledR}$ & Ultrafil & 83,40 \\
\hline Média & & 80,66 \\
\hline 4.1 MBPс & Condensação lateral & 67,80 \\
\hline 4.2 MBPс & Híbrida de Tagger & 24,40 \\
\hline 4.3 MBPс & Ultrafil & 27,60 \\
\hline Média & & 39,93 \\
\hline
\end{tabular}

As Tabelas 2, 3, 4, 5, 6 e 7 demonstram os resultados obtidos com os testes de Kruskal-Wallis e de Dunn, quando comparadas as técnicas de obturação realizadas, independentemente do material utilizado para a confecção do tampão apical. 
Tabela 2: Avaliação da infiltração de Rodamina B a 0,2\% pelo teste não-paramétrico de Kruskal-Wallis, quando considerada apenas a técnica da condensação lateral.

\begin{tabular}{cccc}
\hline Materiais & Mediana & Soma de Postos & Posto Médio \\
& & & \\
\hline Pasta L \& C & 100,000000 & 309,000000 & 30,9000000 \\
\hline MTA-Angelus $^{(}$cinza & 65,5000000 & 158,500000 & 15,8500000 \\
\hline CPM $^{(B)}$ & 75,0000000 & 176,000000 & 17,6000000 \\
\hline MBPc & 56,4000000 & 176,500000 & 17,6500000 \\
\hline $\begin{array}{l}\text { Hc = } 11.08770 \\
\text { Quiquadrado com } 3 \text { graus de liberdade }\end{array}$ & Probabilidade $=0.011260$
\end{tabular}

Tabela 3: Comparação, pelo teste de Dunn, entre os materiais usados como tampão apical, para se determinar o nível de significância entre eles, considerando a técnica da condensação lateral.

\begin{tabular}{|c|c|c|c|}
\hline Comparação & Diferença & Valor crítico & Interpretação \\
\hline $\mathrm{CPM}^{\circledR}$ X Pasta L \& C & $-13,300000$ & 13,4316952 & NS \\
\hline $\mathrm{CPM}^{\circledR} \mathrm{X}$ MBPc & $-0,0500000$ & 13,4316952 & NS \\
\hline CPM $^{\circledR}$ X MTA-Angelus ${ }^{\circledR}$ cinza & 1,75000000 & 13,4316952 & NS \\
\hline Pasta L \& C X MBPc & 13,2500000 & 13,4316952 & NS \\
\hline Pasta L \& C X MTA-Angelus ${ }^{\circledR}$ cinza & 15,0500000 & 13,4316952 & $\mathbf{S}$ \\
\hline MBPc X MTA-Angelus ${ }^{\circledR}$ cinza & 1,80000000 & 13,4316952 & NS \\
\hline
\end{tabular}

Nível de significância $\mathrm{p}<0,05$ 
Tabela 4: Avaliação da infiltração de Rodamina B a 0,2\% pelo teste não-paramétrico de Kruskal-Wallis, quando considerada apenas a técnica híbrida de Tagger.

\begin{tabular}{cccc}
\hline Materiais & Mediana & Soma de Postos & Posto Médio \\
& & & \\
\hline Pasta L \& C & 100,000000 & 320,500000 & 32,0500000 \\
\hline MTA-Angelus $^{\circledR}$ cinza & 49,7000000 & 176,500000 & 17,6500000 \\
\hline CPM $^{\circledR}$ & 89,5000000 & 252,000000 & 25,2000000 \\
\hline MBPc & 19,6000000 & 71,0000000 & 7,10000000 \\
\hline $\begin{array}{l}\text { Hc }=26.00315 \\
\text { Quiquadrado com 3 graus de liberdade }\end{array}$ & Probabilidade $=0.000009$
\end{tabular}

Tabela 5: Comparação, pelo teste de Dunn, entre os materiais usados como tampão apical, para se determinar o nível de significância entre eles, considerando a técnica híbrida de Tagger.

\begin{tabular}{|c|c|c|c|}
\hline Comparação & Diferença & Valor crítico & Interpretação \\
\hline $\mathrm{CPM}^{\circledR} \mathrm{X}$ Pasta L \& C & $-6,8500000$ & 13,4316952 & NS \\
\hline $\mathrm{CPM}^{\circledR} \mathrm{X}$ MBPc & 18,1000000 & 13,4316952 & S \\
\hline $\mathrm{CPM}^{\circledR}$ X MTA-Angelus ${ }^{\circledR}$ cinza & 7,55000000 & 13,4316952 & NS \\
\hline Pasta L \& C X MBPc & 24,9500000 & 13,4316952 & S \\
\hline Pasta L \& C X MTA-Angelus ${ }^{\circledR}$ cinza & 14,4000000 & 13,4316952 & $\mathbf{S}$ \\
\hline MBPc X MTA-Angelus ${ }^{\circledR}$ cinza & $-10,550000$ & 13,4316952 & NS \\
\hline
\end{tabular}

Nível de significância $\mathrm{p}<0,05$. 
Tabela 6: Avaliação da infiltração de Rodamina B a 0,2\% pelo teste não-paramétrico de Kruskal-Wallis, quando considerada apenas a técnica de injeção de guta-percha.

\begin{tabular}{cccc}
\hline Materiais & Mediana & Soma de Postos & Posto Médio \\
& & & \\
\hline Pasta L \& C & 100,000000 & 309,000000 & 30,9000000 \\
\hline MTA-Angelus $^{\circledR}$ cinza & 73,6000000 & 209,500000 & 20,9500000 \\
\hline CPM $^{\circledR}$ & 96,4000000 & 242,500000 & 24,2500000 \\
\hline MBPc & 23,6000000 & 59,0000000 & 5,90000000 \\
\hline $\begin{array}{l}\text { Hc }=26.59584 \\
\text { Quiquadrado com 3 graus de liberdade }\end{array}$ & Probabilidade $=0.000007$
\end{tabular}

Tabela 7: Comparação, pelo teste de Dunn, entre os materiais usados como tampão apical, para se determinar o nível de significância entre eles, utilizando a técnica de injeção de guta-percha.

\begin{tabular}{|c|c|c|c|}
\hline Comparação & Diferença & Valor crítico & Interpretação \\
\hline $\mathrm{CPM}^{\circledR}$ X Pasta L \& C & $-6,6500000$ & 13,4316952 & NS \\
\hline $\mathrm{CPM}^{\circledR}$ X MBPc & 18,3500000 & 13,4316952 & $\mathbf{S}$ \\
\hline $\left.\mathrm{CPM}^{(}\right)$X MTA-Angelus $\left.{ }^{(}\right)$cinza & 3,30000000 & 13,4316952 & NS \\
\hline Pasta L \& C X MBPc & 25,0000000 & 13,4316952 & $\mathrm{~S}$ \\
\hline Pasta L \& C X MTA-Angelus ${ }^{\circledR}$ cinza & 9,9500000 & 13,4316952 & NS \\
\hline 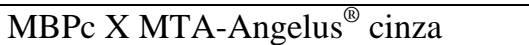 & $-15,050000$ & 13,4316952 & $\mathbf{S}$ \\
\hline
\end{tabular}

Nível de significância $\mathrm{p}<0,05$.

As Tabelas 8, 9, 10, 11, 12, 13, 14 e 15 demonstram os resultados obtidos com os testes de Kruskal-Wallis e de Dunn, quando comparados os materiais utilizados para a confecção do tampão apical, independentemente da técnica de obturação realizada. 
Tabela 8: Avaliação da infiltração de Rodamina B a $0,2 \%$ pelo teste não-paramétrico de Kruskal-Wallis, quando considerado apenas o tampão apical feito com a pasta L \& C.

\begin{tabular}{cccc}
\hline $\begin{array}{c}\text { Técnicas } \\
\text { Obturadoras }\end{array}$ & Mediana & Soma de Postos & Posto Médio \\
\hline Condensação lateral & 100,000000 & 142,500000 & 14,2500000 \\
\hline Híbrida de Tagger & 100,000000 & 154,500000 & 15,4500000 \\
\hline Ultrafil & 100,000000 & 168,000000 & 16,8000000 \\
\hline
\end{tabular}

Hc $=0.860483$

Quiquadrado com 2 graus de liberdade $\quad$ Probabilidade $=0.650351$

Tabela 9: Comparação, pelo teste de Dunn, entre as técnicas obturadoras realizadas, para se determinar o nível de significância entre elas, considerando-se a pasta L \& C.

\begin{tabular}{lccc}
\hline \multicolumn{1}{c}{ Comparação } & Diferença & Valor crítico & Interpretação \\
\hline Condensação lateral X Híbrida de Tagger & $-1,2000000$ & 9,22768417 & NS \\
\hline Condensação lateral X Ultrafil & $-2,5500000$ & 9,22768417 & NS \\
\hline Híbrida de Tagger X Ultrafil & $-1,3500000$ & 9,22768417 & NS \\
\hline
\end{tabular}

Nível de significância $\mathrm{p}<0,05$.

Tabela 10: Avaliação da infiltração de Rodamina B a 0,2\% pelo teste não-paramétrico de Kruskal-Wallis, quando considerado apenas o tampão apical feito com o MTAAngelus ${ }^{\circledR}$ cinza.

$\begin{array}{llll}\text { Técnicas } & \text { Mediana } & \text { Soma de Postos } & \text { Posto Médio }\end{array}$

\section{Obturadoras}

\begin{tabular}{cccc}
\hline Condensação lateral & 65,5000000 & 150,000000 & 15,000000 \\
\hline Híbrida de Tagger & 49,7000000 & 127,500000 & 12,7500000 \\
\hline Ultrafil & 73,6000000 & 187,500000 & 18,7000000
\end{tabular}

Hc $=2.390109$

Quiquadrado com 2 graus de liberdade $\quad$ Probabilidade $=0.302687$ 
Tabela 11: Comparação, pelo teste de Dunn, entre as técnicas obturadoras realizadas, para se determinar o nível de significância entre elas, considerando-se o MTA-Angelus ${ }^{\circledR}$ cinza.

\begin{tabular}{lccc}
\hline \multicolumn{1}{c}{ Comparação } & Diferença & Valor crítico & Interpretação \\
\hline Condensação lateral X Híbrida de Tagger & 2,25000000 & 9,22768417 & NS \\
\hline Condensação lateral X Ultrafil & $-3,7500000$ & 9,22768417 & NS \\
\hline Híbrida de Tagger X Ultrafil & $-6,0000000$ & 9,22768417 & NS \\
\hline
\end{tabular}

Nível de significância $\mathrm{p}<0,05$.

Tabela 12: Avaliação da infiltração de Rodamina B a 0,2\% pelo teste não-paramétrico de Kruskal-Wallis, quando considerado apenas o tampão apical feito com o CPM ${ }^{\circledR}$.

\begin{tabular}{cccc}
\hline $\begin{array}{c}\text { Técnicas } \\
\text { Obturadoras }\end{array}$ & Mediana & Soma de Postos & Posto Médio \\
\hline Condensação lateral & 75,0000000 & 113,500000 & 11,350000 \\
\hline Híbrida de Tagger & 89,5000000 & 169,500000 & 16,9500000 \\
\hline Ultrafil & 96,4000000 & 182,000000 & 18,2000000 \\
\hline $\begin{array}{l}\text { Hc = 3.566705 } \\
\text { Quiquadrado com 2 graus de liberdade }\end{array}$ & Probabilidade $=0.168073$
\end{tabular}

Tabela 13: Comparação, pelo teste de Dunn, entre as técnicas obturadoras realizadas, para se determinar o nível de significância entre elas, considerando-se o CPM ${ }^{\circledR}$.

\begin{tabular}{lccc}
\hline \multicolumn{1}{c}{ Comparação } & Diferença & Valor crítico & Interpretação \\
\hline Condensação lateral X Híbrida de Tagger & $-5,6000000$ & 9,22768417 & NS \\
\hline Condensação lateral X Ultrafil & $-6,8500000$ & 9,22768417 & NS \\
\hline Híbrida de Tagger X Ultrafil & $-1,2500000$ & 9,22768417 & NS \\
\hline
\end{tabular}

Nível de significância $\mathrm{p}<0,05$ 
Tabela 14: Avaliação da infiltração de Rodamina B a 0,2\% pelo teste não-paramétrico de Kruskal-Wallis, quando considerado apenas o tampão apical feito com o MBPc.

\begin{tabular}{cccc}
\hline $\begin{array}{c}\text { Técnicas } \\
\text { Obturadoras }\end{array}$ & Mediana & Soma de Postos & Posto Médio \\
\hline Condensação lateral & 56,4000000 & 235,000000 & 23,500000 \\
\hline Híbrida de Tagger & 19,6000000 & 107,500000 & 10,7500000 \\
\hline Ultrafil & 23,6000000 & 122,500000 & 12,2500000 \\
\hline
\end{tabular}

Hc $=12.55180$

Quiquadrado com 2 graus de liberdade $\quad$ Probabilidade $=0.001881$

Tabela 15: Comparação, pelo teste de Dunn, entre as técnicas obturadoras realizadas, para se determinar o nível de significância entre elas, considerando-se o MBPc.

\begin{tabular}{lccc}
\hline \multicolumn{1}{c}{ Comparação } & Diferença & Valor crítico & Interpretação \\
\hline Condensação lateral X Híbrida de Tagger & 12,7500000 & 9,22768417 & $\mathbf{S}$ \\
\hline Condensação lateral X Ultrafil & 11,2500000 & 9,22768417 & $\mathbf{S}$ \\
\hline Híbrida de Tagger X Ultrafil & $-1,5000000$ & 9,22768417 & NS \\
\hline
\end{tabular}

Nível de significância $\mathrm{p}<0,05$

Para a realização do teste de adaptação, o grupo 1 (Pasta L \& C) foi excluído, deixando-se apenas os grupos 2, 3 e 4, cujos tampões apicais foram confeccionados com os cimentos MTA-Angelus ${ }^{\circledR}$ cinza, CPM $^{\circledR}$ e MBPc, respectivamente. Também foram aplicados os testes de Kruskal-Wallis e de Dunn para a análise dos resultados. Porém, no teste de Kruskal-Wallis ainda foram incluídos os valores do $1^{\circ}$ e do $3^{\circ}$ quartis, para determinar que cinqüenta por cento dos valores obtidos encontram-se nesse intervalo. Deve ser ressaltado que, mesmo com dois espécimes do subgrupo 2.1 (MTA-Angelus ${ }^{\circledR}$ cinza + condensação lateral) e três do subgrupo $3.3\left(\mathrm{CPM}^{\circledR}+\right.$ Ultrafil) perdendo os tampões durante o desgaste longitudinal da raiz, os resultados não foram prejudicados. 
As tabelas 16, 17, 18, 19, 20 e 21 apresentam os resultados obtidos, quando comparados os cimentos utilizados para a confecção dos tampões, de acordo com cada técnica obturadora utilizada.

Tabela 16: Avaliação da adaptação marginal, pelo teste não-paramétrico de KruskalWallis, quando considerada apenas a técnica da condensação lateral.

\begin{tabular}{ccccc}
\hline Materiais & Média ( $\boldsymbol{\mu m})$ & Mediana & $\mathbf{1}^{\mathbf{0}}$ Quartil & $\mathbf{3}^{\mathbf{0}}$ Quartil \\
\hline MTA-Angelus $^{\circledR}$ cinza & 371,54 & 0,00 & 0,00 & 221,99 \\
\hline CPM $^{\circledR}$ & 448,96 & 0,00 & 0,00 & 898,86 \\
\hline MBPc & 306,00 & 0,00 & 0,00 & 539,02
\end{tabular}

$\mathrm{Hc}=0.345823$

Quiquadrado com 2 graus de liberdade

Probabilidade $=0.841211$

Tabela 17: Comparação, pelo teste de Dunn, entre os cimentos usados como tampão apical, para se determinar o nível de significância entre eles, considerando-se a técnica de condensação lateral.

\begin{tabular}{lccc}
\hline \multicolumn{1}{c}{ Comparação } & Diferença & Valor crítico & Interpretação \\
\hline CPM $^{\circledR}$ X MBPc & 1,40000000 & 8,80679164 & NS \\
\hline CPM $^{\circledR}$ X MTA-Angelus ${ }^{\circledR}$ cinza & 1,75000000 & 9,34101314 & NS \\
\hline MBPc X MTA-Angelus $^{\circledR}$ cinza & 0,35000000 & 9,34101314 & NS \\
\hline
\end{tabular}

Nível de significância $\mathrm{p}<0,05$. 
Tabela 18: Avaliação da adaptação marginal, pelo teste não-paramétrico de KruskalWallis, quando considerada apenas a técnica híbrida de Tagger.

\begin{tabular}{ccccc}
\hline Materiais & Média ( $\mathbf{\mu m})$ & Mediana & $\mathbf{1}^{\mathbf{0}}$ Quartil & $\mathbf{3}^{\mathbf{0}}$ Quartil \\
\hline MTA-Angelus $^{(\circledR)}$ cinza & 474,68 & 0,00 & 0,00 & 427,99 \\
\hline CPM $^{(8)}$ & 375,46 & 0,00 & 0,00 & 562,18 \\
\hline MBPc & 525,58 & 0,00 & 0,00 & 323,85 \\
\hline
\end{tabular}

Hc $=0.099873$

Quiquadrado com 2 graus de liberdade $\quad$ Probabilidade $=0.951289$

Tabela 19: Comparação, pelo teste de Dunn, entre os cimentos usados como tampão apical, para se determinar o nível de significância entre eles, considerando-se a técnica híbrida de Tagger.

\begin{tabular}{lccc}
\hline \multicolumn{1}{c}{ Comparação } & Diferença & Valor crítico & Interpretação \\
\hline $\mathrm{CPM}^{\circledR}$ X MBPc & 0,85000000 & 9,22768417 & NS \\
\hline CPM $^{\circledR}$ X MTA-Angelus ${ }^{\circledR}$ cinza & 0,95000000 & 9,22768417 & NS \\
\hline MBPc X MTA-Angelus $^{\circledR}$ cinza & 0,10000000 & 9,22768417 & NS \\
\hline
\end{tabular}

Nível de significância $\mathrm{p}<0,05$.

Tabela 20: Avaliação da adaptação marginal, pelo teste não-paramétrico de KruskalWallis, quando considerada apenas a técnica de injeção de guta-percha.

\begin{tabular}{ccccc}
\hline Materiais & Média $(\boldsymbol{\mu m})$ & Mediana & $\mathbf{1}^{\mathbf{0}}$ Quartil & $\mathbf{3}^{\mathbf{0}}$ Quartil \\
\hline MTA-Angelus $^{\circledR}$ cinza & 334,67 & 0,00 & 0,00 & 533,47 \\
\hline CPM $^{\circledR}$ & 124,84 & 0,00 & 0,00 & 0,00 \\
\hline MBPc & 592,08 & 0,00 & 0,00 & 1194,46 \\
\hline
\end{tabular}

Hc $=1.201926$

Quiquadrado com 2 graus de liberdade

Probabilidade $=0.548283$ 
Tabela 21: Comparação, pelo teste de Dunn, entre os cimentos usados como tampão apical, para se determinar o nível de significância entre eles, considerando-se a técnica de injeção de guta-percha.

\begin{tabular}{lccc}
\hline \multicolumn{1}{c}{ Comparação } & Diferença & Valor crítico & Interpretação \\
\hline CPM $^{\circledR}$ X MBPc & $-3,0857142$ & 9,36399229 & NS \\
\hline CPM $^{\circledR}$ X MTA-Angelus ${ }^{\circledR}$ cinza & $-3,0857142$ & 9,36399229 & NS \\
\hline MBPc X MTA-Angelus $^{\circledR}$ cinza & 0,00000000 & 8,49768454 & NS \\
\hline
\end{tabular}

Nível de significância $\mathrm{p}<0,05$.

As Tabelas 22, 23, 24, 25, 26 e 27 apresentam os resultados obtidos, quando analisados os cimentos utilizados para a confecção dos tampões apicais, em função das técnicas de obturação utilizadas.

Tabela 22: Avaliação da adaptação marginal, pelo teste não-paramétrico de KruskalWallis, quando considerado apenas o cimento MTA-Angelus ${ }^{\circledR}$ cinza.

\begin{tabular}{cccc}
\hline $\begin{array}{c}\text { Técnicas } \\
\text { Obturadoras }\end{array}$ & Mediana & Soma de Postos & Posto Médio \\
& & & \\
\hline Condensação lateral & 0,00000000 & 110,000000 & 13,7500000 \\
\hline Híbrida de Tagger & 0,00000000 & 144,000000 & 14,4000000 \\
\hline Ultrafil & 0,00000000 & 152,000000 & 15,2000000 \\
\hline $\begin{array}{l}\text { Hc }=0.204057 \\
\text { Quiquadrado com 2 graus de liberdade }\end{array}$ & Probabilidade $=0.903003$
\end{tabular}

Tabela 23: Comparação, pelo teste de Dunn, entre as técnicas obturadoras utilizadas, para se determinar o nível de significância entre elas, de acordo com o cimento MTAAngelus ${ }^{\circledR}$ cinza.

\begin{tabular}{lccc}
\hline \multicolumn{1}{c}{ Comparação } & Diferença & Valor crítico & Interpretação \\
\hline Condensação lateral X Híbrida de Tagger & $-0,6500000$ & 9,34101314 & NS \\
\hline Condensação lateral X Ultrafil & $-1,4500000$ & 9,34101314 & NS \\
\hline Híbrida de Tagger X Ultrafil & $-0,8000000$ & 8,80679164 & NS \\
\hline
\end{tabular}

Nível de significância $\mathrm{p}<0,05$ 
Tabela 24: Avaliação da adaptação marginal, pelo teste não-paramétrico de KruskalWallis, quando considerado apenas o cimento $\mathrm{CPM}^{\circledR}$.

\begin{tabular}{cccc}
\hline $\begin{array}{c}\text { Técnicas } \\
\text { Obturadoras }\end{array}$ & Mediana & Soma de Postos & Posto Médio \\
\hline Condensação lateral & 0,00000000 & 152,000000 & 15,2000000 \\
\hline Híbrida de Tagger & 0,00000000 & 147,000000 & 14,7000000 \\
\hline Ultrafil & 0,00000000 & 79,0000000 & 11,2857142
\end{tabular}

Hc $=1.597448$

Quiquadrado com 2 graus de liberdade $\quad$ Probabilidade $=0.449902$

Tabela 25: Comparação, pelo teste de Dunn, entre as técnicas obturadoras utilizadas, para se determinar o nível de significância entre elas, de acordo com o cimento CPM ${ }^{\circledR}$.

\begin{tabular}{lccc}
\hline \multicolumn{1}{c}{ Comparação } & Diferença & Valor crítico & Interpretação \\
\hline Condensação lateral X Híbrida de Tagger & 0,5000000 & 8,49768454 & NS \\
\hline Condensação lateral X Ultrafil & 3,91428571 & 9,36399229 & NS \\
\hline Híbrida de Tagger X Ultrafil & 3,41428571 & 9,36399229 & NS \\
\hline
\end{tabular}

Nível de significância $\mathrm{p}<0,05$

Tabela 26: Avaliação da adaptação marginal, pelo teste não-paramétrico de KruskalWallis, quando considerado apenas o cimento MBPc.

\begin{tabular}{cccc}
\hline $\begin{array}{c}\text { Técnicas } \\
\text { Obturadoras }\end{array}$ & Mediana & Soma de Postos & Posto Médio \\
\hline Condensação lateral & 0,00000000 & 149,000000 & 14,9000000 \\
\hline Híbrida de Tagger & 0,00000000 & 155,000000 & 15,5000000 \\
\hline Ultrafil & 0,00000000 & 161,000000 & 16,1000000 \\
\hline
\end{tabular}

$\mathrm{Hc}=0.141319$

Quiquadrado com 2 graus de liberdade $\quad$ Probabilidade $=0.931778$ 
Tabela 27: Comparação, pelo teste de Dunn, entre as técnicas obturadoras utilizadas, para se determinar o nível de significância entre elas, de acordo com cimento MBPc.

\begin{tabular}{lccc}
\hline \multicolumn{1}{c}{ Comparação } & Diferença & Valor crítico & Interpretação \\
\hline Condensação lateral X Híbrida de Tagger & $-0,6000000$ & 9,22768417 & NS \\
\hline Condensação lateral X Ultrafil & $-1,2000000$ & 9,22768417 & NS \\
\hline Híbrida de Tagger X Ultrafil & $-0,6000000$ & 9,22768417 & NS \\
\hline
\end{tabular}

Nível de significância $\mathrm{p}<0,05$ 
6 - DISCUSSÃO 


\section{Discussão}

\subsection{Das metodologias}

Como relataram LOPES; SIQUEIRA JR.; ESTRELA ${ }^{64}$ (2004), um dos cuidados que se deve ter ao se realizar o tratamento endodôntico, em dentes com rizogênese incompleta, é avaliar as condições anatômicas do canal no terço apical, que poderá apresentar parede de forma divergente, paralela ou ligeiramente convergente.

Levando esse fator em consideração, vários trabalhos apresentam diferentes maneiras de simular dentes com rizogênese incompleta. HACHMEISTER et al. ${ }^{43}$, (2002) por exemplo, utilizaram uma broca de Peeso número 2 até o forame apical e, para deixá-lo divergente, utilizaram um instrumento Profile 50.04, introduzido via apical, até que toda a parte ativa penetrasse no canal radicular, com o forame apical ficando com um diâmetro de $1.14 \mathrm{~mm}$.

Já STUART; SCHWARTZ; BEESON ${ }^{100}$, (2006), utilizaram uma broca de Peeso número 5 ultrapassando o forame apical, o que o deixou com um diâmetro de 1,5mm. AL-KAHTANI et al. ${ }^{5}$ (2005) também simularam dentes com rizogênese incompleta. Para isso, cortaram os $2 \mathrm{~mm}$ apicais das raízes, e a forma divergente do forame foi conseguida com o uso de uma broca de Gates Glidden número 3 e de um instrumento Profile 50.04, ambos via retrógrada.

Neste trabalho, a metodologia empregada baseou-se no estudo de MATT et al. ${ }^{71}$, (2004), que consistiu na utilização, primeiramente, das brocas de Gates Glidden em ordem decrescente (no sentido coroa-ápice), da número 5 à número 1, até que esta última ultrapassasse o forame apical em 1mm; em seguida, utilizou-se limas tipo $\mathrm{K}$, iniciando-se com a de número 50 e terminando com a de número 90, de modo que todas as limas ultrapassassem o forame apical em 1mm, resultando em um forame com diâmetro de 0,92mm. A única diferença entre este estudo e o de MATT et al. ${ }^{71}$ está no fato de que, enquanto, nesse último as coroas dentais foram seccionadas, tal procedimento não foi realizado neste trabalho e, sim, feitas as aberturas coronárias de todos os dentes, com a intenção de que se mantivessem as condições encontradas na realidade clínica. Além disso, o fator mais importante para a escolha desta metodologia baseou-se no fato de esta ser a única em que se realizou a instrumentação dos canais radiculares, pois, ao se utilizar os instrumentos endodônticos, iniciando-se com o de número 50 até o de número 90, considera-se que o canal foi preparado, diferentemente 
do que foi feito nos trabalhos de HACHMEISTER et al. ${ }^{43}$, que utilizaram broca de Peeso número 2, via coronária, e instrumento Profile 50.04, via apical, AL-KAHTANI et al. ${ }^{5}$, que utilizaram apenas broca de Peeso número 5, e STUART; SCHWARTZ; BEESON $^{100}$, que fizeram uso de broca de Gates Glidden número 3 e instrumento Profile 50.04, ambos via retrógrada. Como, clinicamente, a manobra do tampão apical é realizada após o preparo químico-mecânico do canal, julgou-se a metodologia proposta por MATT et al. ${ }^{71}$ como sendo a mais interessante para ser adotada nesta pesquisa.

A importância da impermeabilização externa das raízes, com o intuito de não permitir a entrada de corante pelos túbulos dentinários e canais acessórios, foi relatada por vários autores $\left(\right.$ MORAES $^{73}, 1981$, MORAES $^{74}$, 1984, SPÄNGBERG; ACIERNO; CHA ${ }^{96}$, 1989, LEE; MONSEF; TORABINEJAD ${ }^{57}$, 1993, TORABINEJAD; WATSON; PITT FORD ${ }^{110}$, 1993, CHAU et al. ${ }^{25}$, 1997, MANOCCI; VICHI; FERRARI $^{68}, 1997$, AQRABAWI $^{9}, 2000$, VINHOLES $^{113}$, 2000). A mais utilizada nos trabalhos é a impermeabilização com esmalte para unhas (MORAES ${ }^{73}, 1981$; MATLOFF et al. ${ }^{70}$, 1982; BERBERT et al. ${ }^{14}$, 1983; BARNETT et al. ${ }^{11}$, 1989), entretanto, a cera pegajosa também pode ser utilizada (DOW; INGLE ${ }^{30}$, 1955), assim como o cianoacrilato de etila (SHIMABUKO ${ }^{85}$, 1997). Neste estudo, utilizou-se a impermeabilização externa com Araldite e esmalte para unhas, a exemplo de outros trabalhos (MORAES ${ }^{74}$, 1984, SIQUEIRA JR.; GARCIA FILHO ${ }^{92}$, 1994, SIQUEIRA JR.; FRAGA; GARCIA ${ }^{91}$, 1995, BRANDÃO ${ }^{22}$, 1999, YAMASHITA et al. ${ }^{124}$, 1999, SILVA NETO ${ }^{87}$, 2002, TANOMARU FILHO; FIGUEIREDO; TANOMARU ${ }^{103}$, 2005, CONEGLIAN; BRAMANTE; OROSCO ${ }^{27}$, 2005), tendo a mesma se mostrado bastante eficiente.

Outro fator bastante importante é a maneira de se levar o material à porção apical do canal radicular e, também, como compactá-lo sem que haja extravasamento para os tecidos periapicais. TORABINEJAD; CHIVIAN $^{105}$, (1999), ao indicarem, clinicamente, o uso do MTA como tampão apical, propuseram a utilização de um portaamálgama para levá-lo ao canal radicular, enquanto a condensação do mesmo deveria ser feita com pontas de papel absorvente ou condensadores manuais. Já AMINOSHARIAE; HARTWELL; MOON ${ }^{6}$, (2003), compararam a adaptação do MTA, quando levado ao canal radicular e condensado por duas técnicas diferentes, sendo elas a condensação manual ou a ultra-sônica. Verificaram que a condensação manual foi melhor que a condensação ultra-sônica, o que difere dos resultados obtidos por WHITERSPOON; HAM ${ }^{116}$ (2001), LAWLEY et al. ${ }^{56}$ (2004) e YEUNG; LIEWEHR; 
MOON $^{126}$ (2006). Porém, segundo os últimos autores, o estudo realizado por eles difere, em muito, do feito por AMINOSHARIAE; HARTWELL; MOON ${ }^{6}$. Explicam que, enquanto o seu estudo foi quantitativo, o dos outros autores foi qualitativo, sendo que a análise foi limitada à visão superficial do material e, desta forma, espaços vazios internos poderiam passar despercebidos, enquanto que a análise quantitativa que mensurou o peso do MTA no canal promoveu uma avaliação mais precisa da densidade da obturação. Além disso, enquanto AMINOSHARIAE; HARTWELL; MOON ${ }^{6}$, primeiramente, colocavam manualmente o MTA nos canais radiculares para, somente então, utilizarem uma ponta ultra-sônica diretamente sobre o material, YEUNG; LIEWEHR; MOON ${ }^{126}$ utilizaram a ativação ultra-sônica indiretamente, pois a ponta do aparelho ativava um condensador e, este, sim, condensava o MTA. WHITERSPOON; $\mathrm{HAM}^{116}$ afirmaram que a utilização do ultra-som para ativar o condensador manual permitiu o escoamento do MTA para o ápice radicular, melhorando a sua adaptação, enquanto LAWLEY et al. ${ }^{56}$ relataram um aumento significativo na capacidade de selamento do MTA quando o ultra-som foi utilizado.

Outra maneira de se levar o MTA ao canal radicular foi proposta por BRAMANTE; BORTOLUZZI; BROON ${ }^{20}$, (2004), que utilizaram uma espiral Lentulo a $2 \mathrm{~mm}$ do comprimento de trabalho. Após o preenchimento do terço apical do canal, com a espiral Lentulo, a condensação do material é feita com uma lima tipo K compatível com o calibre do canal e com sua ponta envolta em algodão. Esta foi a técnica utilizada neste trabalho, tanto para o MTA como para o $\mathrm{CPM}^{\circledR}$, já que ambos são cimentos muito semelhantes, pois considerou-se que, com a utilização da espiral Lentulo, consegue-se levar o material ao terço apical com certa facilidade, rapidamente e com eficiência. Contudo, deve-se ressaltar que ocorreu extravasamento de material em todos os canais, durante a confecção dos tampões apicais com MTA e CPM ${ }^{\circledR}$. Já para o MBPc, como não se encontrou relato na literatura sobre o modo de inserção do material no canal radicular, foi sugerido por seu idealizador que fossem confeccionados pequenos “cilindros” de cimento e, presos à ponta de uma lima, fossem levados ao terço apical do canal radicular e ali depositados, liberando-os ao se rotacionar a lima no sentido anti-horário. O extravasamento deste cimento também ocorreu durante a confecção dos tampões apicais, em todos os canais. Em razão disso, concordamos com BERNABÉ; HOLLAND ${ }^{16}$, (2003), que afirmam que, para prevenir, clinicamente, o extravasamento de MTA durante a sua colocação em casos de forames apicais dilatados, como ocorre em dentes com rizogênese incompleta, deve ser colocada uma base apical 
de hidróxido de cálcio, em pó ou em pasta, junto aos tecidos periapicais para, em seguida, colocar-se o MTA sobre o hidróxido de cálcio, diminuindo-se o risco de sobreobturação. Esta medida também estaria indicada para o $\mathrm{CPM}^{\circledR}$ e para o $\mathrm{MBPc}$. Todavia, é importante salientar que este procedimento não foi realizado, neste estudo, porque um dos objetivos do trabalho era verificar se um tampão apical de $5 \mathrm{~mm}$ de espessura seria suficiente para se evitar a infiltração de Rodamina B e, também, se o tampão permaneceria adaptado após a obturação com três técnicas diferentes.

Aliás, a espessura do tampão apical é outro ponto muito questionável. HACHMEISTER et al. $^{43}$, (2002), afirmaram que o problema em relação à infiltração não estaria na espessura do tampão apical, e sim na maneira de condensar esse material, pois, quando usado em obturações retrógradas, a infiltração bacteriana foi significativamente menor. Basearam-se no fato de que, em obturações retrógradas, o MTA seria mais bem compactado, já que, nesses casos, ele seria condensado contra um cone de guta-percha ou uma matriz, que serviriam como suporte para esse material. Isto não é possível quando da colocação do MTA como tampão apical em dentes com rizogênese incompleta, logo, a adaptação às paredes dentinárias ficaria prejudicada. Concordamos que a colocação, não apenas do MTA, como também do $\mathrm{CPM}^{\circledR}$ e do MBPc, é muito mais difícil quando feita via coronária, em comparação à via retrógrada. Por isso, como já foi dito, julgamos ser necessária a colocação de uma base de hidróxido de cálcio ou de outro material de preenchimento como, por exemplo, o sulfato de cálcio, de 1 a 2mm de espessura, anteriormente à colocação do tampão apical com o material escolhido. Porém, consideramos que a espessura do tampão apical é de fundamental importância para o sucesso do tratamento. Várias espessuras foram testadas em diferentes estudos, variando de 1mm (HACHMEISTER et al. ${ }^{43}$, 2002; VALOIS; COSTA JR. ${ }^{111}$, 2004) até 10mm (AMINOSHARIAE; HARTWELL; $\mathrm{MOON}^{6}$, 2003). Contudo, os valores mais constantes e que apresentaram melhores resultados estão entre 3 e 5mm de espessura. Para muitos autores (KWAK; PARK; $\mathrm{OH}^{55}$, 2000; HACHMEISTER et al. ${ }^{43}$, 2002; GIULIANI et al. ${ }^{40}$, 2002; VALOIS; COSTA JR. ${ }^{111}$, 2004; BRAMANTE; BORTOLUZZI; BROON ${ }^{20}$, 2004; LAWLEY et al. $^{56}$, 2004), a utilização de um tampão apical com $4 \mathrm{~mm}$ de espessura já seria suficiente para promover um bom selamento do canal radicular. Como este estudo foi baseado na metodologia proposta por MATT et al. ${ }^{71}$, optou-se por confeccionar os tampões apicais com 5mm de espessura, pois, os resultados obtidos pelos referidos autores, assim como 
os alcançados por AL-KAHTANI et al. ${ }^{5}$, (2005) e CONEGLIAN; BRAMANTE; OROSCO $^{27}$, (2005), em seus estudos, corroboraram para esta escolha.

O momento da obturação da porção remanescente do canal radicular, após a manobra do tampão apical, também tem gerado algumas discussões. Para KWAK; PARK; $\mathrm{OH}^{55}$, 2000; WHITERSPOON; HAM ${ }^{116}$, 2001; STEINIG; REGAN; GUTMANN $^{99}$, 2003, que realizaram estudos com o MTA, a obturação poderia ser realizada na mesma sessão em que o tampão apical fosse confeccionado. Porém, no estudo realizado por MATT et al. $^{71}$, ao comparar as técnicas mediata e imediata de obturação, verificou-se que a primeira apresentou resultados superiores, com significância estatística. Além disso, casos clínicos, como os de SHABAHANG; TORABINEJAD $^{82}$, 2000; GÓMEZ ${ }^{41}$, 2000; LEVENSTEIN ${ }^{60}$, 2000; GIULIANI et al. ${ }^{40}$, 2002; LYNN; EINBENDER ${ }^{65}$, 2003; LINSUWANONT ${ }^{61}$, 2003; MAROTO et al. ${ }^{69}$, 2003, reiteram os resultados obtidos por MATT et al. ${ }^{71}$, pois, em todos os casos clínicos citados, a técnica de obturação mediata foi utilizada. Somos da opinião de que, para a realização da obturação, o cimento utilizado para a confecção do tampão apical já deva ter tomado presa e ser resistente à compressão exercida durante a execução da obturação, para evitar possíveis extravasamentos, pois, sendo cimentos, a reabsorção é dificultada. De acordo com VASCONCELOS ${ }^{112}$, (2006), o MTA-Angelus ${ }^{\circledR}$ cinza apresenta um tempo de presa inicial de cerca de 8 minutos, e final por volta de 32 minutos. Já o $\mathrm{CPM}^{\circledR}$ apresenta presa inicial de 22 minutos e presa final de 61 minutos; por fim, o MBPc apresenta cerca de 121 minutos para a presa inicial e 224 minutos para a final. Considerando tais valores e, também, o fato de que a resistência do MTA à compressão é, inicialmente, baixa, aumentando com o passar do tempo, julgamos ser mais apropriado obturar a porção remanescente do canal radicular em uma segunda sessão. Assim, em concordância com BRAMANTE; BORTOLUZZI; BROON ${ }^{20}$, (2004), que recomendaram a colocação de uma pasta aquosa de hidróxido de cálcio, preenchendo o restante do canal radicular, durante o intervalo entre as sessões. Neste trabalho, após a confecção dos tampões nos dentes dos grupos 2, 3 e 4, todos os remanescentes dos canais radiculares foram preenchidos com uma pasta aquosa de hidróxido de cálcio. Particularmente, em relação ao MTA, a pasta de hidróxido de cálcio serviria, não só para substituir a colocação de uma bolinha de algodão umedecida, como foi proposto por TORABINEJAD; CHIVIAN ${ }^{105}$, (1999), mas, também, para agir como um curativo de demora no intervalo das sessões. BRAMANTE; BORTOLUZZI; BROON ${ }^{20}$, (2004), afirmaram que a colocação da 
bolinha de algodão umedecida poderia provocar um excesso de umidade no tampão apical, comprometendo, assim, sua estabilidade, daí optar-se pelo preenchimento do restante do canal com a pasta de hidróxido de cálcio. Além disso, de acordo com BERNABÉ; HOLLAND ${ }^{16}$, (2003), a hidratação necessária para o endurecimento do MTA se faz, também, pelo contato do material com os tecidos periapicais, o que dispensaria a colocação da bolinha de algodão umedecida sobre o mesmo. Há que ser lembrado que a pasta de hidróxido de cálcio, sendo aquosa, poderá ofertar umidade ao MTA.

Quanto à escolha dos materiais utilizados neste estudo, a opção pela pasta L \& C se fez por, na literatura, encontrar-se o trabalho de LOPES; COSTA FILHO ${ }^{63}$, (1988), que utilizou tal material como tampão apical em dentes unirradiculados, despolpados e com lesões periapicais. A pasta L \& C foi introduzida no mercado por Lopes e Costa Filho, em 1984, sendo a marca patenteada e registrada por eles. Essa pasta foi idealizada em 1978, tendo por base estudos anteriores do Prof. Dr. Mário Roberto Leonardo (LOPES; COSTA FILHO ${ }^{62}$, 1984). Assim, como a pasta L \& C apresenta, na própria bula, a utilização como tampão apical como uma de suas indicações clínicas, optou-se pela inclusão desse material, como grupo controle, para a avaliação da infiltração de Rodamina B, levando-se em consideração que a utilização de tal material poderia substituir o hidróxido de cálcio em pó, clinicamente, quando a necessidade da manobra do tampão apical se fizesse presente, pois, como afirmaram FAVA; SAUNDERS ${ }^{34}$, (1999), a utilização de um veículo oleoso, na pasta L \& C, faz com que esta apresente baixa solubilidade, com liberação lenta e contínua de hidróxido de cálcio, além de incrementar as propriedades físicas do mesmo, o que dificultaria a sua remoção do canal radicular, diferentemente do que ocorre com o hidróxido de cálcio em pó.

Já, no caso do MTA cinza, a escolha se fez em razão deste material ter sido constantemente utilizado em casos clínicos que necessitaram de um tampão apical (SHABAHANG; TORABINEJAD ${ }^{82}$, 2000, GÓMEZ ${ }^{41}$, 2000, LEVENSTEIN ${ }^{60}, 2000$, GIULIANI et al. $^{40}$, 2002, LYNN; EINBENDER ${ }^{65}, 2003$, LINSUWANONT ${ }^{61}, 2003$, MAROTO et al. ${ }^{69}$, 2003, BRAMANTE; BORTOLUZZI; BROON ${ }^{20}$, 2004), com excelentes resultados. A opção pela utilização do MTA-Angelus ${ }^{\circledR}$ cinza, em detrimento ao ProRoot MTA ${ }^{\circledR}$ cinza (Dentsply/Tulsa Dental, Estados Unidos da América), deveuse à facilidade em se conseguir o primeiro material, além da intenção de se avaliar um material de fabricação nacional. 
Com relação ao $\mathrm{CPM}^{\circledR}$, tal material é apresentado com tendo as mesmas, ou melhores, propriedades físicas, químicas e biológicas em comparação ao MTA, com as mesmas indicações clínicas $\left(\mathrm{CASTRO}^{24}, 2003\right.$, BRAMANTE et al. ${ }^{21}$ ). Como esse material também é um agregado de trióxido mineral, este estudo procurou avaliar a possibilidade de utilizá-lo com tampão e, também, analisar sua capacidade seladora e sua adaptação marginal, já que não existem muitos estudos sobre o $\mathrm{CPM}^{\circledR}$.

Por fim, o MBPc foi utilizado por ser um material experimental, que teve algumas propriedades físicas e químicas já avaliadas (PAVAN ${ }^{77}, 1999$, SILVA NETO; MORAES $^{88}$, 2003, SIQUEIRA et al. ${ }^{90}$, 2004, VASCONCELOS ${ }^{112}$, 2006), com ótimos resultados, além de um trabalho que avaliou as propriedades biológicas (CINTRA et al. $\left.^{26}, 2006\right)$. Como as indicações clínicas iniciais desse material incluem apenas a sua utilização em obturações retrógradas $\left(\operatorname{PAVAN}^{77}\right.$, 1999) e perfurações radiculares (SILVA NETO; MORAES ${ }^{88}$, 2002), procurou-se avaliar a possibilidade de utilizá-lo na confecção de tampão apical.

Com relação às técnicas de obturação utilizadas neste trabalho, o uso da técnica da condensação lateral justifica-se por ser, ela, a mais utilizada clinicamente. Já a utilização da técnica de injeção de guta-percha plastificada reside no fato de que tal técnica foi bastante empregada nos casos clínicos relatados na literatura (SHABAHANG; TORABINEJAD $^{82}$, 2000, GÓMEZ ${ }^{41}$, 2000, GIULIANI et al. ${ }^{40}, 2002$, LEVENSTEIN $^{60}$, 2002, LINSUWANONT ${ }^{61}$, 2003, KRATCHMAN ${ }^{53}$, 2004, XU et al. $^{122}$, 2006), porém, com o sistema Obtura II. Optou-se pelo sistema Ultrafil pela facilidade de aquisição, e por não diferir em muito das características técnicas do sistema Obtura II. Segundo GUTMANN; WHITERSPOON ${ }^{42}$, (2000), a diferença entre os sistemas Obtura II e Ultrafil encontra-se, basicamente, na temperatura necessária para a plastificação da guta-percha a ser injetada no canal. Enquanto, no sistema Obtura II, a guta-percha é aquecida até, aproximadamente, $185^{\circ}$ a $200^{\circ} \mathrm{C}$, no sistema Ultrafil a guta-percha se plastifica a uma temperatura de, aproximadamente, $70^{\circ}$ a $90^{\circ} \mathrm{C}$. Além disso, neste sistema a guta-percha encontra-se disponível em três consistências diferentes, de acordo com a viscosidade: regular (baixa viscosidade), firm set (viscosidade moderada) e endoset (alta viscosidade). Neste estudo, a guta-percha utilizada foi a firm set, que endurece após 4 minutos. Esta técnica tem a vantagem de não exercer pressão exagerada em direção apical, desde que corretamente realizada.

Já a técnica híbrida de Tagger (TAGGER et al. ${ }^{101}$, 1984) recebeu esta denominação por consistir na associação da técnica da condensação lateral com a 
termocompactação mecânica, proposta por McSpadden. De acordo com BONETTI FILHO et al. ${ }^{18}$, (1998), a vantagem desta técnica é que ela permite ao profissional corrigir quantas vezes for necessária a obturação do canal radicular. Afirmaram, ainda, que a técnica híbrida de Tagger está indicada para todos os casos, com exceção dos dentes com rizogênese incompleta. Esta foi a razão pela qual se incluiu esta técnica neste trabalho, pois procurou-se avaliar se, com a utilização de um tampão apical, que pudesse impedir o extravasamento de material, tal técnica tornar-se-ia viável para esses casos, já que promove uma boa qualidade de selamento (TAGGER et al. ${ }^{101}$, 1984).

Quanto à forma de se analisar a capacidade seladora de materiais obturadores e/ou retrobturadores do canal radicular, várias foram relatadas e estudadas. Dentre elas, pode-se citar a avaliação da infiltração de radioisótopos (HOLLAND et al. $^{50}, 1975$, BENNER et al. ${ }^{13}, 1981$, MORAES $^{73}, 1981$, BERBERT et al. ${ }^{14}$, 1983), de endotoxinas (TANG; TORABINEJAD; KETTERING ${ }^{102}$, 2002), de bactérias (TORABINEJAD et al. ${ }^{108}$, 1995, ADAMO et al. ${ }^{3}$, 1999, HACHMEISTER et al. ${ }^{43}$, 2002, MANGIN et al. ${ }^{67}$, 2003, FERRIS; BAUMGARTNER ${ }^{38}$, 2004, LEIMBURG et al. $^{58}, 2004$, AL-KAHTANI et al. ${ }^{5}, 2005$ ), de saliva humana (AL-HEZAIMI et al. ${ }^{4}$, 2005), de um complexo protéico (VALOIS; COSTA JR. ${ }^{111}$, 2004), por meio do transporte de fluidos (BATES; CARNES; DEL RIO ${ }^{12}$, 1996), e por meio de corantes MORAES $^{73}$, 1981, MORAES ${ }^{74}$, 1984, ANJOS ${ }^{8}$, 1985, LEE; MONSEF; TORABINEJAD ${ }^{57}$, 1993, TORABINEJAD; WATSON; PITT FORD ${ }^{110}$, 1993, TORABINEJAD et al. ${ }^{106}$, 1994, BRANDÃO ${ }^{22}$, 1999, KWAK; PARK; $\mathrm{OH}^{55}$, 2000, SILVA NETO; MORAES ${ }^{88}$, 2003, VIZGIRDA et al. ${ }^{114}$, 2004, MATT et al. ${ }^{71}, 2004$, KUBO; GOMES; MANCINI ${ }^{54}$, 2005, XAVIER et al. ${ }^{121}$, 2005, CONEGLIAN; BRAMANTE; OROSCO ${ }^{27}$, 2005).

Entre os corantes utilizados, o destaque maior sempre foi para o azul de metileno, em diferentes concentrações (LEE; MONSEF; TORABINEJAD ${ }^{57}$, 1993, TORABINEJAD et al. ${ }^{106}$, 1994, BRANDÃO ${ }^{22}$, 1999, KWAK; PARK; $\mathrm{OH}^{55}$, 2000, VIZGIRDA et al. ${ }^{114}$, 2004, MATT et al. $^{71}$, 2004, BRANDÃO ${ }^{23}$, 2005). Porém, em 1998, WU; KONTAKIOTIS; WESSELINK ${ }^{117}$, após a realização de um interessante trabalho, afirmaram que o azul de metileno sofre descoloração quando em contato com alguns materiais obturadores, o que pode mostrar resultados irreais para tais materiais em estudos de infiltração. A descoloração do azul de metileno ocorre já que o mesmo é instável quando em contato com materiais alcalinos, causando a hidrólise do azul de metileno e resultando em um composto chamado thional, que é transparente. Isso 
explicaria a razão pela qual o azul de metileno é descolorido pelo hidróxido de cálcio. Com relação ao MTA, o óxido de cálcio presente neste material poderia, em contato com a água, formar o hidróxido de cálcio, o que causaria a descoloração do azul de metileno.

A mesma opinião é compartilhada por MORAES et al. ${ }^{76}$, 2000, MORAES et al. $^{75}$, 2005, TANOMARU FILHO; FIGUEIREDO; TANOMARU ${ }^{103}$, 2005, e BRANDÃO ${ }^{23}$, 2005. Assim, ao se determinar a realização do teste de infiltração de corante para avaliar a capacidade de selamento da pasta L \& C e dos cimentos MTAAngelus $^{\circledR}$ cinza, $\mathrm{CPM}^{\circledR}$ e MBPc, neste trabalho, optou-se pela Rodamina B a 0,2\% em detrimento ao azul de metileno, apoiando-se nos trabalhos citados, já que a Rodamina B não tem o seu poder de marcação influenciado por materiais alcalinos (MORAES et al. $^{75}$, 2005, TANOMARU FILHO; FIGUEIREDO; TANOMARU ${ }^{103}, \quad 2005$, BRANDÃO $\left.{ }^{23}, 2005\right)$.

Um fator que poderia afetar os resultados seria o tempo de permanência dos dentes imersos no corante, como foi demonstrado por MORAES ${ }^{74}$ (1984) e HOLLAND et al. $^{51}$ (1991), que verificaram maiores infiltrações após imersão em corante, por períodos mais longos. Estudos como os de SHIMABUKO ${ }^{85}$ (1997) e VINHOLES ${ }^{113}$ (2000) utilizaram o período de sete dias para avaliar a infiltração de Rodamina B. Já TORABINEJAD; WATSON; PITT FORD ${ }^{110}$ (1993) e MORAES $^{73}$ (1981) consideram que o período de 24 horas já é suficiente para avaliar a infiltração. Neste estudo, optouse por um período intermediário, de 48 horas, utilizado por SILVA NETO; MORAES ${ }^{88}$ (2003) e por outros autores (LEE; MONSEF; TORABINEJAD ${ }^{57}, 1993$, CHAU et al. ${ }^{25}$, 1997, MANNOCCI; VICHI; FERRARI ${ }^{68}, 1997$, YAMASHITA et al. ${ }^{124}$, 1999), embora utilizando outras soluções corantes.

$\mathrm{O}$ pH da solução corante também poderia afetar a quantidade de infiltração, como relataram WU; WESSELINK ${ }^{118}$ (1993). Este fato foi demonstrado por STARKEY; ANDERSON; PASHLEY ${ }^{98}$, (1993), que realizaram um estudo mostrando que $\mathrm{pH}$ abaixo de 5,0 causa perdas consideráveis de estrutura dental, o que não ocorre quando o pH da solução corante é de 7,0. Neste estudo, o pH utilizado para a solução corante de Rodamina B a 0,2\% foi de 7,0.

O método mais utilizado para expor a interface obturação/parede dentinária e possibilitar a medida da infiltração de corante é o seccionamento longitudinal (DAZEY; SENIA ${ }^{29}$, 1990, LEE; MONSEF; TORABINEJAD ${ }^{57}, 1993$, TORABINEJAD; WATSON; PITT FORD ${ }^{109}$, 1993, MANNOCCI; VICHI; 
FERRARI $^{68}, 1997$, CHAU et al. $^{25}$, 1997, SHIMABUKO ${ }^{85}$, 1997, BRANDÃO ${ }^{22}, 1999$, PAVAN $^{77}, 1999$, YAMASHITA et al. ${ }^{124}$, 1999, AQRABAWI ${ }^{9}, 2000$, VINHOLES $^{113}$, 2000, SILVA NETO; MORAES ${ }^{88}$, 2003). Porém, neste trabalho, optou-se pelo desgaste longitudinal, com discos de carburundum, de uma das faces proximais, até que o tampão apical e o material obturador fossem expostos, conforme estudo realizado por CONEGLIAN; BRAMANTE; OROSCO ${ }^{27}$ (2005). Contudo, durante o desgaste, houve o deslocamento de dois tampões de MTA cinza e de três de $\mathrm{CPM}^{\circledR}$. Para a análise da infiltração de Rodamina B, estes espécimes ainda foram considerados, pois foi possível visualizar a marcação do corante na dentina. Já, para a avaliação da adaptação marginal, tais espécimes foram excluídos.

A utilização do software Image Tool 3.0 para a obtenção das medidas de infiltração de Rodamina B é muito simples e fácil de ser executada, além de ser confiável, o que o torna válido. No caso da infiltração de corante, existem outras maneiras de se avaliar os resultados, destacando-se a leitura em microscopia óptica (MORAES $^{74}$, 1984, DAZEY; SENIA ${ }^{29}$, 1990, LEE; MONSEF; TORABINEJAD ${ }^{57}$, 1993, MANNOCCI; VICHI; FERRARI ${ }^{68}$, 1997, CHAU et al. ${ }^{25}$, 1997, BRANDÃO ${ }^{22}$, 1999, YAMASHITA et al. ${ }^{124}$, 1999, AQRABAWI ${ }^{9}, 2000$, VINHOLES $^{113}, 2000$, SILVA NETO; MORAES ${ }^{88}$, 2003) e um método baseado na análise da área da penetração de corante, avaliado pela captação de imagem e contagem de "pixels” por um microcomputador (SHIMABUKO ${ }^{85}$, 1997, PAVAN $^{77}$, 1999). Além disso, julgamos que a utilização do software Image Tool 3.0 é mais confiável e objetiva do que a atribuição de escores numéricos (TORABINEJAD; WATSON; PITT FORD ${ }^{110}$, 1993,

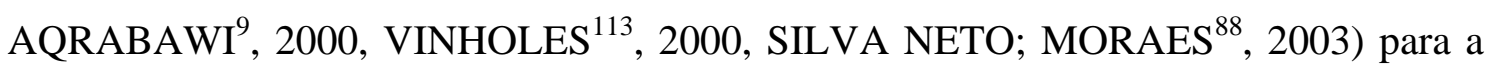
obtenção de uma média de infiltração, já que a mensuração feita com o software permite que sejam obtidos valores, em milímetros de extensão, no caso deste estudo, de quanto o corante infiltrou tornando, inclusive, o teste estatístico mais confiável.

A utilização de três examinadores, tanto para a análise da infiltração de Rodamina como da adaptação marginal, de forma independente um do outro, foi feita para que os resultados obtidos fossem considerados mais precisos, o que poderia não acontecer no caso de se utilizar apenas um examinador.

No caso da adaptação marginal, fez-se uso do microscópio eletrônico de varredura para observar diretamente a interface material/parede dentinária nos segmentos de $5 \mathrm{~mm}$ dos noventa espécimes que foram metalizados. Aliás, a metalização destes segmentos foi um ponto que gerou muita discussão, pois, conforme estudo 
realizado por TORABINEJAD et al. ${ }^{109}$, em 1995, poderiam ocorrer trincas, durante a metalização, que afetariam a obtenção dos resultados. Segundo os autores, uma maneira de se evitar tais inconvenientes seria a moldagem dos segmentos e a obtenção de réplicas de resina, que seriam levadas ao microscópio eletrônico de varredura. Porém, como outros estudos utilizaram a metalização de segmentos dentários (SILVA NETO ${ }^{87}$, 2002, SHIPPER et al. ${ }^{86}$, 2004, XAVIER et al. ${ }^{121}$, 2005), com bons resultados, optou-se, então, pela metalização dos segmentos dentários. Não ocorreu trinca em qualquer segmento que foi metalizado, o que possibilitou a mensuração da desadaptação de todos eles, com exceção dos cinco espécimes que perderam os tampões durante o desgaste longitudinal das raízes.

O software Image Tool 3.0 também foi utilizado para a avaliação da adaptação e a mensuração da desadaptação marginal dos materiais utilizados como tampão apical. As fotomicrografias foram levadas ao programa de computador, que permitiu a mensuração, de forma linear, em micrometros, da extensão da desadaptação. Diferentemente do estudo de SHIPPER et al. ${ }^{86}$, 2004, que utilizou oito pontos fixos para verificar onde ocorriam as desadaptações e, então, mensurá-las, ou ainda, dos estudos de TORABINEJAD et al. $^{109}$, 1995, e XAVIER et al. ${ }^{121}$, 2005, em que os autores determinaram quatro pontos fixos para analisar a adaptação marginal, optou-se, neste estudo, por não se determinar pontos fixos, e sim mensurar a desadaptação que existisse em qualquer ponto dos $5 \mathrm{~mm}$ do tampão apical.

Assim, para que todo o tampão apical pudesse ser visualizado nas fotomicrografias, utilizou-se um aumento de 35X e, para mostrar, tanto a adaptação quanto a desadaptação dos materiais em relação à parede dentinária, foram feitas fotomicrografias com aumento de 150X.

\subsection{Dos resultados}

\subsubsection{Da avaliação da capacidade seladora por meio da infiltração de Rodamina B.}

Os resultados foram obtidos avaliando-se, primeiramente, a infiltração que ocorreu nos materiais usados como tampões apicais, dentro de cada técnica obturadora. Posteriormente, a infiltração de Rodamina B foi avaliada dentro de cada grupo, 
buscando-se analisar a influência das técnicas obturadoras na infiltração ocorrida em cada material utilizado.

Analisando-se a Tabela 1, percebe-se que, no geral, sem considerar-se as técnicas obturadoras utilizadas, a capacidade seladora dos tampões apicais, com os diversos materiais utilizados pode ser classificada, em ordem decrescente da seguinte maneira: MBPc (com média de 39,93\% de infiltração), MTA-Angelus ${ }^{\circledR}$ cinza $(67,73 \%)$, $\mathrm{CPM}^{\circledR}$ (80,66\%) e pasta L \& C (98,46\% de infiltração, em média).

Ao se considerar a pasta $L \& C$, por tratar-se de um material que não toma presa, o selamento por ela propiciado fica prejudicado, daí, tal resultado poder ser encarado como dentro da normalidade. Contudo, MACHADO ${ }^{66}$ (2000) encontrou bom selamento com a pasta L \& C em obturações de canais radiculares, bem como FARIA ${ }^{33}$ (2004), quando comparou a pasta L \& C com o MTA e o óxido de zinco e eugenol, em retrobturações. Há que ressaltar que esses autores utilizaram como marcador da infiltração o azul de metileno que, comprovadamente, é dissolvido por materiais alcalinos, mormente pelo hidróxido de cálcio. Neste trabalho, o marcador utilizado foi a Rodamina $B$, que não sofre alteração do seu poder de marcação como o azul de metileno (MORAES et al. $^{76}$, 2000, MORAES et al. ${ }^{75}$, 2005, TANOMARU FILHO; FIGUEIREDO; TANOMARU ${ }^{103}, 2005$, e BRANDÃO ${ }^{23}$, 2005).

$\mathrm{Na}$ literatura, apenas as citações de $\mathrm{CASTRO}^{24}$ (2003) e BRAMANTE et al. $^{21}$ (2006) permitem alguma comparação do CPM ${ }^{\circledR}$ com os resultados deste trabalho. Segundo os autores o $\mathrm{CPM}^{\circledR}$ possui, além de outras, as propriedades de adesão e estabilidade dimensional ao longo do tempo. Contudo, os resultados observados com esse material, quanto ao selamento, não foram os melhores, com média de 80,66\% de infiltração, no geral. Quanto à capacidade de aderência citada por CASTRO ${ }^{24}$ (2003) e BRAMANTE et al. ${ }^{21}$ (2006), paira alguma dúvida, pois, durante o desgaste dos dentes para expor o tampão, 10\% deles (3 dentes) se soltaram, demonstrando não tão boa aderência.

Já, quanto ao MTA, seja o Pro Root MTA e o próprio MTA-Angelus ${ }^{\circledR}$ cinza, utilizado nesta pesquisa, vários autores têm salientado sua grande capacidade seladora (LEE; MONSEF; TORABINEJAD ${ }^{57}$, 1993, TORABINEJAD; WATSON; PITT FORD $^{110}$, 1993, TORABINEJAD et al. ${ }^{108}$, 1995, TORABINEJAD et al. ${ }^{109}$, 1995, BATES; CARNES; DEL RIO ${ }^{12}$, 1996, MANGIN et al. ${ }^{67}, 2003$, XAVIER et al. ${ }^{121}$, 2005). Em contrapartida, no trabalho de SILVA NETO; $\operatorname{MORAES}^{88},(2003)$, o MTA não foi considerado tão bom selador. Quando utilizado como tampão apical o MTA, 
principalmente, na espessura de 4 a $5 \mathrm{~mm}$, tem demonstrado ter grande capacidade seladora (KWAK; PARK; $\mathrm{OH}^{55}$, 2000; HACHMEISTER et al. ${ }^{43}$, 2002; GIULIANI et al. $^{40}$, 2002; VALOIS; COSTA JR. ${ }^{111}$, 2004; LAWLEY et al. ${ }^{56}$, 2004, MATT et al. ${ }^{71}$, 2004, AL-KAHTANI et al. ${ }^{5}, 2005$, CONEGLIAN; BRAMANTE; OROSCO ${ }^{27}$, 2005). Assim, os resultados observados com o MTA-Angelus ${ }^{\circledR}$ cinza, nesta pesquisa, corroboram aqueles encontrados nos trabalhos citados.

Há que ressaltar que 2 dos 30 tampões desse grupo, também, soltaram-se durante o desgaste da raiz, denotando falta de adesão dos mesmos.

Já, em relação ao MBPc, os poucos trabalhos que testaram sua capacidade seladora (SILVA NETO; MORAES ${ }^{88}$, 2003, usando Rodamina B em perfurações, e SIQUEIRA et al. ${ }^{90}$, 2004, utilizando-se da infiltração bacteriana em obturações retrógradas) têm demonstrado ser ele um bom selador. Este fato também foi constatado, nesta pesquisa, onde o MBPc ocupou o primeiro lugar, no geral, com apenas 39,93\% de infiltração, inclusive com diferenciação estatística em relação à pasta L \& C e ao CPM ${ }^{\circledR}$ quando consideradas as técnicas híbrida de Tagger e injeção de guta-percha e, em relação ao MTA-Angelus ${ }^{\circledR}$ cinza, considerando-se a técnica de injeção de guta-percha.

Assim, quando analisada a infiltração ocorrida nos espécimes que tiveram os remanescentes dos canais obturados pela técnica da condensação lateral (Tabelas 2 e 3), observa-se que não houve diferença estatisticamente significante entre os materiais, com exceção da comparação entre o cimento MTA-Angelus ${ }^{\circledR}$ cinza e a pasta L \& C, com supremacia do cimento.

Analisando-se apenas os espécimes obturados pela técnica híbrida de Tagger (Tabelas 4 e 5), novamente o MTA-Angelus ${ }^{\circledR}$ cinza, quando comparado à pasta L \& C, apresentou superioridade estatisticamente significante. Também com significância estatística foi a comparação entre os cimento MBPc e $\mathrm{CPM}^{\circledR}$ e entre o MBPc e a pasta L \& C, com superioridade para o MBPc nos dois casos.

Quando avaliados os resultados obtidos pela técnica de injeção de gutapercha plastificada, com o sistema Ultrafil (Tabelas 6 e 7), foi verificado que o MBPc foi melhor, inclusive com significância estatística, em relação aos demais materiais. Tais resultados apontam, dessa forma, que ao se confeccionar o tampão apical com o cimento MBPc, a técnica obturadora que deveria ser utilizada para o preenchimento da porção remanescente do canal radicular seria a de injeção de guta-percha plastificada. Contudo, considerando-se apenas o grupo do MBPc, a Tabela 1 mostra que, numericamente, a técnica híbrida de Tagger propiciou melhor selamento. Assim, esta 
técnica também estaria indicada quando da confecção de tampão com o MBPc. Em muitos relatos de casos clínicos encontrados na literatura (SHABAHANG; TORABINEJAD ${ }^{82}, 2000$, GÓMEZ ${ }^{41}, 2000$, GIULIANI et al. ${ }^{40}, 2002$, LEVENSTEIN $^{60}$, 2002, LINSUWANONT ${ }^{61}$, 2003, KRATCHMAN ${ }^{53}$, 2004, XU et al. ${ }^{122,123}$, 2006), a técnica obturadora utilizada foi a de injeção de guta-percha plastificada, porém o sistema utilizado foi o Obtura II e, também, em todos esses casos os tampões apicais foram feitos com MTA. Neste estudo, ao se comparar os resultados obtidos para o MTA-Angelus ${ }^{\circledR}$ cinza (Tabelas 10 e 11), variando-se as técnicas obturadoras, verificouse que não houve diferença estatisticamente significante entre elas. Contudo, a utilização do sistema Ultrafil, para esse material, foi a que apresentou os maiores índices de infiltração.

Também não se encontrou diferença estatística quando avaliados o cimento $\mathrm{CPM}^{\circledR}$ (Tabelas 12 e 13) e a pasta L \& C (Tabelas 8 e 9) variando-se as técnicas obturadoras. O único grupo que apresentou diferença estatística significante foi o que utilizou o MBPc como tampão apical. Nesse grupo, as técnicas híbrida de Tagger e de injeção de guta-percha plastificada tiveram desempenho superior à técnica da condensação lateral (Tabelas 14 e 15).

\subsubsection{Da análise da adaptação dos materiais às paredes dentinárias.}

Como já foi relatado, para a análise da adaptação dos materiais às paredes dentinárias o grupo 1 (pasta L \& C), foi excluído, já que um dos objetivos desse estudo foi avaliar a adaptação marginal apenas dos cimentos utilizados como tampões apicais.

Os resultados mostraram que, ao se comparar a adaptação marginal entre os materiais, para cada técnica obturadora utilizada não houve diferença estatisticamente significante em qualquer caso. Porém, deve ser ressaltado que, para a técnica da condensação lateral, o cimento MBPc apresentou o melhor resultado (Tabelas 16 e 17). Já, quando utilizadas as técnicas híbrida de Tagger (Tabelas 18 e 19) e a de injeção de guta-percha plastificada (Tabelas 20 e 21), o cimento CPM $^{\circledR}$ foi o que apresentou os melhores índices de adaptação marginal.

Quando comparados os resultados intra-grupos, para cada cimento, variando-se as técnicas obturadoras, também não se constatou diferença estatística significante (Tabelas 22, 23, 24, 25, 26 e 27). 
Os resultados obtidos apontam, assim, uma superioridade do cimento $\mathrm{CPM}^{\circledR}$ quanto à adaptação marginal às paredes dentinárias, mesmo não sendo detectada diferença estatisticamente significante entre os grupos.

\subsection{Considerações gerais}

Na realização de uma pesquisa, dessa natureza, muitas variáveis estão presentes. Procurou-se eliminar o máximo delas, porém, muitas permaneceram.

Cuidados foram tomados para que apenas um operador realizasse todas as etapas operatórias, buscando sempre que o cansaço não interferisse nos procedimentos. Assim, procurou-se que, para cada material, para cada técnica operatória, as condições fossem sempre as mesmas, isto é, para a confecção dos tampões, por exemplo, estipulou-se um determinado período de tempo, evitando que o cansaço pudesse interferir na qualidade dos mesmos.

Não há dúvidas de que alguma dificuldade existe para a colocação, principalmente dos cimentos, na altura do terço apical, de maneira que se possa ter o material bem condensado, tomando contato com as paredes dos canais, formando um tampão compacto, inclusive, com a dificuldade imposta pelo forame aberto. Pelas fotomicrografias percebe-se que, no geral, os tampões foram bem confeccionados, no entanto, a desadaptação observada sempre esteve presente na região mais apical, demonstrando a falta de um anteparo durante a condensação dos cimentos.

Sendo os cimentos MTA-Angelus ${ }^{\circledR}$ cinza e $\mathrm{CPM}^{\circledR}$ pastosos no momento da inserção, o uso de espiral Lentulo e a conseqüente compactação com lima envolta em algodão facilitaria o contato do material com as paredes do canal. Entretanto, o cimento MBPc possui uma consistência espessa, não se espalha facilmente dentro do canal, devendo ser condensado para entrar em contato com as paredes do canal. A falta de um anteparo é algo prejudicial. Outra observação interessante, com esse cimento, é que a porção (cilindro) a ser levada ao terço apical deve ter um diâmetro menor do que o do canal. Por ser um material consistente, ao possuir o mesmo diâmetro do canal, agiria como um êmbolo, impedindo um refluxo do ar aprisionado nos terços médio a apical do canal, fato que impediria a adaptação do tampão no local desejado. Todavia, tomandose os devidos cuidados, a sua colocação é bastante simples. 
Especificamente, em relação ao cimento MBPc, a análise da Tabela 1 permite observar que há uma discrepância muito grande em relação à infiltração observada quando da técnica da condensação lateral e as outras duas (híbrida de Tagger e Ultrafil).

Ao se comparar a técnica da condensação lateral, que sabidamente exerce pressão do material obturador em direção apical, com a técnica de injeção de gutapercha era de se esperar um melhor resultado para a primeira, o que não ocorreu. Entretanto, numericamente, a técnica híbrida de Tagger, contra-indicada em casos de arrombamento de forames ou ápices incompletos, foi a que proporcionou o melhor resultado. Isto também ocorreu no grupo do MTA-Angelus ${ }^{\circledR}$ cinza, porém, com esse material, a infiltração marginal da Rodamina B, permitida pelos tampões, pelo menos numericamente, foi menor nos casos obturados com a técnica da condensação lateral, em relação à Ultrafil, diferentemente da do grupo do MBPc.

Outra observação interessante, que pode ser levantada em relação às metodologias utilizadas, nesta pesquisa, é a questão da correlação entre a capacidade seladora (infiltração marginal) e a adaptação dos tampões, considerando-se os cimentos utilizados.

Alguns autores (STABHOLTZ et al. ${ }^{97}$, 1985, SILVA $\mathrm{NETO}^{87}$, 2002) afirmaram haver uma correlação entre infiltração e adaptação marginal, pois, segundo eles, maiores desadaptações dos materiais às paredes dentinárias resultariam em maiores índices de infiltração. Nesse estudo, tal correlação não existiu, assim como nos trabalhos de ABDAL; RETIEF ${ }^{1}$, 1982, YOSHIMURA; MARSHALL, TINKLE ${ }^{127}$, 1990, e XAVIER et al. ${ }^{121}$, 2005. Os resultados mostraram que o cimento MBPc foi o que apresentou os menores índices de infiltração. Contudo, ao se analisar os resultados do teste de adaptação, o cimento que apresentou os melhores resultados foi o $\mathrm{CPM}^{\circledR}$, e esse mesmo cimento apresentou os piores índices de infiltração de Rodamina B, sendo superior, apenas, ao grupo controle (pasta L \& C).

Também não é possível afirmar que as técnicas obturadoras tenham influenciado os resultados, tanto de infiltração como de adaptação marginal. No caso do teste de infiltração, o único grupo que apresentou diferença estatística significante, quando comparadas as técnicas obturadoras, foi o cimento MBPc (Tabela 15). Nos demais grupos não houve diferença significante, o que nos faz acreditar que, realmente, não há correlação entre infiltração e adaptação marginal, pois o MBPc teve o maior índice de infiltração registrado quando utilizou-se a técnica de condensação lateral, e 
este mesmo material apresentou seu melhor índice de adaptação quando esta mesma técnica obturadora foi utilizada.

No teste de adaptação, não houve diferença estatística significante em qualquer grupo, mostrando que as técnicas obturadoras não influenciaram a adaptação dos cimentos às paredes dentinárias.

No tocante à correlação entre a infiltração marginal e a adaptação, vale conjecturar sobre as limitações dos métodos de avaliação. Assim, embora a avaliação, tanto da infiltração quanto da adaptação, tenha sido realizada nos mesmos locais, não há como afirmar que aquilo que se vê ao microscópio eletrônico de varredura seja o que ocorreu em toda a circunferência do canal. Adaptações melhores em alguns pontos podem ter ocorrido, mesmo nos casos onde se observou desadaptação ao M.E.V. Dessa maneira, como o selamento é a reprodução do ocorrido em toda a circunferência do canal, aquela desadaptação local, talvez, não seja o retrato fiel do que ocorreu em toda a área do tampão. Assim, fica, realmente, difícil que haja uma correlação entre a infiltração e a adaptação marginal.

Sem dúvida, o entendimento daquilo tudo que a pesquisa está revelando, ainda, está um tanto limitado. Assim, novas pesquisas deverão ser conduzidas no futuro, para que as dúvidas possam ser sanadas. 


\section{7 - CONCLUSÕES}




\section{CONCLUSÕES}

Considerando as metodologias utilizadas neste estudo e os resultados obtidos, podem ser apresentadas as seguintes conclusões:

7.1 O cimento MBPc apresentou os menores índices de infiltração de Rodamina B a 0,2\%, com diferença estatística significante para os demais materiais;

7.2 O cimento $\mathrm{CPM}^{\circledR}$ apresentou os melhores resultados quando avaliada a adaptação às paredes do canal radicular, porém sem significância estatística;

7.3 As três técnicas obturadoras utilizadas não influenciaram a capacidade seladora e nem a adaptação dos tampões apicais; 
ANEXOS 
ANEXO 1: Valores expressos, em porcentagem (\%), da infiltração marginal de Rodamina B a 0,2\% nos espécimes cujos tampões apicais foram confeccionados com a pasta L \& C, e média geral de cada subgrupo, em função das técnicas obturadoras utilizadas.

\begin{tabular}{|c|c|c|c|}
\hline \multirow[t]{2}{*}{ Espécimes } & \multicolumn{3}{|c|}{ Técnicas Obturadoras } \\
\hline & Condensação lateral & Híbrida de Tagger & Ultrafil \\
\hline 1 & 93,2 & - & - \\
\hline 2 & 100,0 & - & - \\
\hline 3 & 99,2 & - & - \\
\hline 4 & 100,0 & - & - \\
\hline 5 & 100,0 & - & - \\
\hline 6 & 100,0 & - & - \\
\hline 7 & 100,0 & - & - \\
\hline 8 & 100,0 & - & - \\
\hline 9 & 91,6 & - & - \\
\hline 10 & 100,0 & - & - \\
\hline 11 & - & 96,6 & - \\
\hline 12 & - & 100,0 & - \\
\hline 13 & - & 100,0 & - \\
\hline 14 & - & 87,0 & - \\
\hline 15 & - & 100,0 & - \\
\hline 16 & - & 100,0 & - \\
\hline 17 & - & 100,0 & - \\
\hline 18 & - & 100,0 & - \\
\hline 19 & - & 100,0 & - \\
\hline 20 & - & 100,0 & - \\
\hline 21 & - & - & 100,0 \\
\hline 22 & - & - & 100,0 \\
\hline 23 & - & - & 100,0 \\
\hline 24 & - & - & 100,0 \\
\hline 25 & - & - & 100,0 \\
\hline 26 & - & - & 100,0 \\
\hline 27 & - & - & 100,0 \\
\hline 28 & - & - & 87,0 \\
\hline 29 & - & - & 100,0 \\
\hline 30 & - & - & 100,0 \\
\hline Média & 98,4 & 98,4 & 98,6 \\
\hline
\end{tabular}


ANEXO 2: Valores expressos, em porcentagem (\%), da infiltração marginal de Rodamina B a 0,2\% nos espécimes cujos tampões apicais foram confeccionados com o cimento MTA - Angelus ${ }^{\circledR}$ cinza, e média geral de cada subgrupo, em função das técnicas obturadoras utilizadas.

\begin{tabular}{|c|c|c|c|}
\hline \multirow[t]{2}{*}{ Espécimes } & \multicolumn{3}{|c|}{ Técnicas Obturadoras } \\
\hline & Condensação lateral & Híbrida de Tagger & Ultrafil \\
\hline 31 & 39,2 & - & - \\
\hline 32 & 51,0 & - & - \\
\hline 33 & 98,4 & - & - \\
\hline 34 & 95,4 & - & - \\
\hline 35 & 10,0 & - & - \\
\hline 36 & 43,6 & - & - \\
\hline 37 & 36,0 & - & - \\
\hline 38 & 80,0 & - & - \\
\hline 39 & 100,0 & - & - \\
\hline 40 & 100,0 & - & - \\
\hline 41 & - & 55,6 & - \\
\hline 42 & - & 100,0 & - \\
\hline 43 & - & 21,4 & - \\
\hline 44 & - & 30,4 & - \\
\hline 45 & - & 43,8 & - \\
\hline 46 & - & 31,8 & - \\
\hline 47 & - & 87,0 & - \\
\hline 48 & - & 40,0 & - \\
\hline 49 & - & 97,2 & - \\
\hline 50 & - & 90,4 & - \\
\hline 51 & - & - & 100,0 \\
\hline 52 & - & - & 73,6 \\
\hline 53 & - & - & 100,0 \\
\hline 54 & - & - & 68,4 \\
\hline 55 & - & - & 67,4 \\
\hline 56 & - & - & 57,8 \\
\hline 57 & - & - & 76,8 \\
\hline 58 & - & - & 100,0 \\
\hline 59 & - & - & 73,6 \\
\hline 60 & - & - & 63,2 \\
\hline Média & 65,4 & 59,8 & 78,0 \\
\hline
\end{tabular}


ANEXO 3: Valores expressos, em porcentagem (\%), da infiltração marginal de Rodamina B a 0,2\% nos espécimes cujos tampões apicais foram confeccionados com o cimento $\mathrm{CPM}^{\circledR}$, e média geral de cada subgrupo, em função das técnicas obturadoras utilizadas.

\begin{tabular}{|c|c|c|c|}
\hline \multirow[t]{2}{*}{ Espécimes } & \multicolumn{3}{|c|}{ Técnicas Obturadoras } \\
\hline & Condensação lateral & Híbrida de Tagger & Ultrafil \\
\hline 61 & 65,6 & - & - \\
\hline 62 & 100,0 & - & - \\
\hline 63 & 40,0 & - & - \\
\hline 64 & 81,2 & - & - \\
\hline 65 & 92,2 & - & - \\
\hline 66 & 84,6 & - & - \\
\hline 67 & 86,8 & - & - \\
\hline 68 & 68,8 & - & - \\
\hline 69 & 58,8 & - & - \\
\hline 70 & 58,8 & - & - \\
\hline 71 & - & 67,6 & - \\
\hline 72 & - & 83,8 & - \\
\hline 73 & - & 92,6 & - \\
\hline 74 & - & 100,0 & - \\
\hline 75 & - & 100,0 & - \\
\hline 76 & - & 100,0 & - \\
\hline 77 & - & 38,0 & - \\
\hline 78 & - & 100,0 & - \\
\hline 79 & - & 86,4 & - \\
\hline 80 & - & 82,2 & - \\
\hline 81 & - & - & 68,4 \\
\hline 82 & - & - & 100,0 \\
\hline 83 & - & - & 100,0 \\
\hline 84 & - & - & 100,0 \\
\hline 85 & - & - & 92,6 \\
\hline 86 & - & - & 100,0 \\
\hline 87 & - & - & 92,8 \\
\hline 88 & - & - & 100,0 \\
\hline 89 & - & - & 45,8 \\
\hline 90 & - & - & 43,2 \\
\hline Média & 73,6 & 85,0 & 83,4 \\
\hline
\end{tabular}


ANEXO 4: Valores expressos, em porcentagem (\%), da infiltração marginal de Rodamina B a 0,2\% nos espécimes cujos tampões apicais foram confeccionados com o cimento MBPc, e média geral de cada subgrupo, em função das técnicas obturadoras utilizadas.

\begin{tabular}{|c|c|c|c|}
\hline \multirow[t]{2}{*}{ Espécimes } & \multicolumn{3}{|c|}{ Técnicas Obturadoras } \\
\hline & Condensação lateral & Híbrida de Tagger & Ultrafil \\
\hline 91 & 100,0 & - & - \\
\hline 92 & 100,0 & - & - \\
\hline 93 & 56,4 & - & - \\
\hline 94 & 54,2 & - & - \\
\hline 95 & 49,2 & - & - \\
\hline 96 & 50,6 & - & - \\
\hline 97 & 56,4 & - & - \\
\hline 98 & 15,2 & - & - \\
\hline 99 & 95,4 & - & - \\
\hline 100 & 100,0 & - & - \\
\hline 101 & - & 9,4 & - \\
\hline 102 & - & 25,8 & - \\
\hline 103 & - & 35,2 & - \\
\hline 104 & - & 11,8 & - \\
\hline 105 & - & 34,2 & - \\
\hline 106 & - & 13,4 & - \\
\hline 107 & - & 12,2 & - \\
\hline 108 & - & 37,8 & - \\
\hline 109 & - & 13,4 & - \\
\hline 110 & - & 51,2 & - \\
\hline 111 & - & - & 41,2 \\
\hline 112 & - & - & 27,0 \\
\hline 113 & - & - & 9,4 \\
\hline 114 & - & - & 17,6 \\
\hline 115 & - & - & 22,4 \\
\hline 116 & - & - & 7,0 \\
\hline 117 & - & - & 65,8 \\
\hline 118 & - & - & 24,8 \\
\hline 119 & - & - & 18,8 \\
\hline 120 & - & - & 42,4 \\
\hline Média & 67,8 & 24,4 & 27,6 \\
\hline
\end{tabular}


ANEXO 5: Valores expressos, em micrômetros $(\mu \mathrm{m})$, da adaptação marginal do cimento MTA - Angelus ${ }^{\circledR}$ cinza, utilizado na confecção dos tampões apicais nos 3 subgrupos testados, e média geral de cada subgrupo, em função das técnicas obturadoras utilizadas.

\begin{tabular}{|c|c|c|c|}
\hline \multirow[t]{2}{*}{ Espécimes } & \multicolumn{3}{|c|}{ Técnicas Obturadoras } \\
\hline & Condensação lateral & Híbrida de Tagger & Ultrafil \\
\hline 31 & 887,95 & - & - \\
\hline 32 & 0,00 & - & - \\
\hline 33 & tampão ausente & - & - \\
\hline 34 & 0,00 & - & - \\
\hline 35 & tampão ausente & - & - \\
\hline 36 & 0,00 & - & - \\
\hline 37 & 2084,38 & - & - \\
\hline 38 & 0,00 & - & - \\
\hline 39 & 0,00 & - & - \\
\hline 40 & 0,00 & - & - \\
\hline 41 & - & 0,00 & - \\
\hline 42 & - & 960,97 & - \\
\hline 43 & - & 0,00 & - \\
\hline 44 & - & 3215,13 & - \\
\hline 45 & - & 0,00 & - \\
\hline 46 & - & 0,00 & - \\
\hline 47 & - & 0,00 & - \\
\hline 48 & - & 0,00 & - \\
\hline 49 & - & 0,00 & - \\
\hline 50 & - & 570,65 & - \\
\hline 51 & - & - & 552,23 \\
\hline 52 & - & - & 0,00 \\
\hline 53 & - & - & 992,34 \\
\hline 54 & - & - & 1324,97 \\
\hline 55 & - & - & 0,00 \\
\hline 56 & - & - & 0,00 \\
\hline 57 & - & - & 477,17 \\
\hline 58 & - & - & 0,00 \\
\hline 59 & - & - & 0,00 \\
\hline 60 & - & - & 0,00 \\
\hline Média & 371,54 & 474,68 & 334,67 \\
\hline
\end{tabular}


ANEXO 6: Valores expressos, em micrômetros $(\mu \mathrm{m})$, da adaptação marginal do cimento $\mathrm{CPM}^{\circledR}$, utilizado na confecção dos tampões apicais nos 3 subgrupos testados, e média geral de cada subgrupo, em função das técnicas obturadoras utilizadas.

\begin{tabular}{|c|c|c|c|}
\hline \multirow[t]{2}{*}{ Espécimes } & \multicolumn{3}{|c|}{ Técnicas Obturadoras } \\
\hline & Condensação lateral & Híbrida de Tagger & Ultrafil \\
\hline 61 & 0,00 & - & - \\
\hline 62 & 0,00 & - & - \\
\hline 63 & 1267,38 & - & - \\
\hline 64 & 0,00 & - & - \\
\hline 65 & 1052,34 & - & - \\
\hline 66 & 0,00 & - & - \\
\hline 67 & 0,00 & - & - \\
\hline 68 & 0,00 & - & - \\
\hline 69 & 1731,41 & - & - \\
\hline 70 & 438,48 & - & - \\
\hline 71 & - & 0,00 & - \\
\hline 72 & - & 606,06 & - \\
\hline 73 & - & 0,00 & - \\
\hline 74 & - & 0,00 & - \\
\hline 75 & - & 0,00 & - \\
\hline 76 & - & 925,67 & - \\
\hline 77 & - & 1792,31 & - \\
\hline 78 & - & 430,54 & - \\
\hline 79 & - & 0,00 & - \\
\hline 80 & - & 0,00 & - \\
\hline 81 & - & - & tampão ausente \\
\hline 82 & - & - & 0,00 \\
\hline 83 & - & - & 0,00 \\
\hline 84 & - & - & 873,88 \\
\hline 85 & - & - & 0,00 \\
\hline 86 & - & - & 0,00 \\
\hline 87 & - & - & tampão ausente \\
\hline 88 & - & - & 0,00 \\
\hline 89 & - & - & tampão ausente \\
\hline 90 & - & - & 0,00 \\
\hline Média & 448,96 & 375,46 & 124,84 \\
\hline
\end{tabular}


ANEXO 7: Valores expressos, em micrômetros $(\mu \mathrm{m})$, da adaptação marginal do cimento MBPc, utilizado na confecção dos tampões apicais nos 3 subgrupos testados, e média geral de cada subgrupo, em função das técnicas obturadoras utilizadas.

\begin{tabular}{|c|c|c|c|}
\hline \multirow[t]{2}{*}{ Espécimes } & \multicolumn{3}{|c|}{ Técnicas Obturadoras } \\
\hline & Condensação lateral & Híbrida de Tagger & Ultrafil \\
\hline 91 & 0,00 & - & - \\
\hline 92 & 718,70 & - & - \\
\hline 93 & 0,00 & - & - \\
\hline 94 & 0,00 & - & - \\
\hline 95 & 0,00 & - & - \\
\hline 96 & 0,00 & - & - \\
\hline 97 & 1276,95 & - & - \\
\hline 98 & 0,00 & - & - \\
\hline 99 & 1068,06 & - & - \\
\hline 100 & 0,00 & - & - \\
\hline 101 & - & 0,00 & - \\
\hline 102 & - & 0,00 & - \\
\hline 103 & - & 0,00 & - \\
\hline 104 & - & 0,00 & - \\
\hline 105 & - & 0,00 & - \\
\hline 106 & - & 1569,21 & - \\
\hline 107 & - & 430,67 & - \\
\hline 108 & - & 0,00 & - \\
\hline 109 & - & 3258,64 & - \\
\hline 110 & - & 0,00 & - \\
\hline 111 & - & - & 0,00 \\
\hline 112 & - & - & 2653,64 \\
\hline 113 & - & - & 1674,26 \\
\hline 114 & - & - & 0,00 \\
\hline 115 & - & - & 0,00 \\
\hline 116 & - & - & 0,00 \\
\hline 117 & - & - & 0,00 \\
\hline 118 & - & - & 0,00 \\
\hline 119 & - & - & 1592,61 \\
\hline 120 & - & - & 0,00 \\
\hline Média & 306,37 & 525,85 & 592,08 \\
\hline
\end{tabular}




\section{REFERÊNCIAS}




\section{REFERÊNCIAS}

1. Abdal AK, Retief H. The apical seal via the retro surgical approach - I. A preliminary study. Oral Surg. 1982 June; 53(6):614-621.

2. Abedi HR, Ingle JI. Mineral trioxide aggregate: a review of a new cement. J Calif Dent Assoc. 1995 Dec; 23(12):36-39.

3. Adamo HL, Buruiana R, Schertzer L, Boylan RJ. A comparison of MTA, Super-EBA, composite and amalgam as root-end filling materials using a bacterial microleakage model. Int Endod J. 1999 May; 32(3):197-203.

4. Al-Hezaimi K, Naghshbandi J, Oglesby S, Simon JHS, Rotstein I. Human saliva penetration of root canals obturated with two types of mineral trioxide aggregate cements. J Endod. 2005 June; 31(6):453-456.

5. Al-Kahtani A, Shostad S, Schifferle R, Bhambhani S. In vitro evaluation of microleakage of an orthograde apical plug of mineral trioxide aggregate in permanente teeth with simulated immature apices. J Endod. 2005 Feb;31(2):117-119.

6. Aminoshariae A, Hartwell GR, Moon PC. Placement of mineral trioxide aggregate using two different techniques. J Endod. 2003 Oct; 29(10):679-682.

7. Andreasen JO, Munksgaard EC, Bakland LK. Comparison of fracture resistance in root canals of immature sheep teeth after filling with calcium hydroxide or MTA. Dent Traumatol. 2006 June; 22(3):154-156.

8. Anjos NM. Avaliação “in vitro” do potencial de infiltração de corantes, em função do tempo e do veículo usado, em obturações de canais radiculares. [dissertação]. Bauru (SP): Faculdade de Odontologia de Bauru, Universidade de São Paulo, 1985. 
9. Aqrabawi J. Sealing ability of amalgam, Super-EBA cement, and MTA when used as retrograde filling materials. Br Dent J. 2000 Mar; 188(5):266-268.

10. Araújo RA, Bueno CES, Delboni MG, Rocha DGP. Avaliação do selamento apical após retrobturações com a utilização de duas diferentes marcas de MTA. J Bras Endod. 2004 Abr/Jun; 5(17):150-156.

11. Barnett F, Trope M, Rooney J, Tronstad L. In vivo sealing ability of calcium hydroxide-containing root canal sealers. Endod Dent Traumatol. 1989 Feb; 5(1):23-26.

12. Bates CF, Carnes DL, del Rio CE. Longitudinal sealing ability of mineral trioxide aggregate as a root-end filling material. J Endod. 1996 Nov; 22(11):575-578.

13. Benner MD, Peters DD, Grower M, Bernier WE. Evaluation of a new thermoplastic gutta-percha obturation technique using ${ }^{45}$ Ca. J Endod. 1981 Nov; 7(11):500-508.

14. Berbert A, Moraes IG, Bramante CM, Bernardineli N, Coradazzi JL. Extrusão de cimento e infiltração apical de ${ }^{131}$ INa em obturações de canais, com e sem condensação lateral. Estomat Cult 1983 Jan/Jun; 13(1):24-29.

15. Berger CR, Lima LBC, Possagno R. Tratamento endodôntico em dentes permanentes com rizogênese incompleta, utilizando hidróxido de cálcio com veículo oleoso. Rev Bras Odontol. 2001 Mar/Abr; 58(2):95-98.

16. Bernabé PFE, Holland R. MTA e cimento Portland: considerações sobre as propriedades físicas, químicas e biológicas. In: Cardoso RJA, Machado MEL. Odontologia arte e conhecimento. São Paulo: Artes Médicas; 2003, p.225-264. 
17. Bittencourt AZ, Mallmann J, Rezende EV. Comportamento da polpa após pulpotomia e recobrimento com materiais à base de hidróxido de cálcio e de óxido de zinco e eugenol. Rev Bras Odontol. 1997 Mai/Jun; 54(3):138-142.

18. Bonetti Filho I, Leonardo RT, Leonardo MR, Leal JM. Obturação dos canais radiculares - técnicas de termoplastificação de guta-percha. In: Leonardo MR, Leal JM. Endodontia - tratamento de canais radiculares. 3a ed. São Paulo: Panamericana; 1998. p.625-642.

19. Brady JE, Himel VT, Weir JC. Periapical response to an apical plug of dentin filings intentionally placed after root canal overinstrumentation. J Endod 1985 Aug; 11(8):323-329.

20. Bramante CM, Bortoluzzi EA, Broon NJ. Agregado trióxido mineral (MTA) como plug apical para la obturación de conductos radiculares: descripción de la técnica y caso clínico. Endodoncia 2004 Jul-Sept; 22(3):155-161.

21. Bramante CM, Bramante AS, Moraes IG, Bernardineli N, Garcia RB. CPM es MTA: nuevos materiales de uso em endodoncia - experiencias clinicas en el manejo de los materiales. Rev Fac Odontol. 2006 17:7-10.

22. Brandão CG. Propriedades físico-químicas dos cimentos endodônticos resinosos Sealer 26, e dos experimentais Sealer Plus e MBP, comparadas às do óxido de zinco e eugenol. [dissertação]. Bauru (SP): Faculdade de Odontologia de Bauru, Universidade de São Paulo; 1999.

23. Brandão CG. Confiabilidade dos testes de infiltração apical com azul de metileno, rodamina B e sistema de transporte de fluído em obturações de canais após o uso de curativo de hidróxido de cálcio. [tese]. Bauru (SP): Faculdade de Odontologia de Bauru, Universidade de São Paulo; 2005.

24. Castro G. Trióxidos minerales agregados - CPM y EndoCPMsealer [monografia]. Buenos Aires: Centro de Investigaciones Odontológicas; 2003. 
25. Chau JYM, Hutter JW, Mork TO, Nicoll BK. An in vitro study of furcation perforation repair using calcium phosphate cement. J Endod. 1997 Sept; 23(9):588-592.

26. Cintra LTA, Moraes IG, Bernabé PFE, Gomes-Filho JE, Bramante CM, Garcia $\mathrm{RB}$, et al. Evaluation of the tissue response to MTA and MBPc: microscopic analysis of implants in alveolar bone of rats. J Endod. 2006 June; 32(6):556559.

27. Coneglian PZA, Bramante CM, Orosco FA. Avaliação in vitro da capacidade de selamento de plugs de MTA cinza, MTA branco e cimento Portland branco. In: Anais da $18^{\mathrm{a}}$ Jornada Odontológica de Bauru "Prof. Dr. José Valdes Conti”; 2005 agosto 23-26; Bauru, SP. 2005. p.3.

28. Coviello J, Brilliant JD. A preliminary clinical study on the use of tricalcium phosphate as an apical barrier. J Endod 1979 Jan; 5(1):6-13.

29. Dazey S, Senia S. An in vitro comparison of sealing ability of materials placed in lateral root perforations. J Endod. 1990 Jan; 16(1):19-23.

30. Dow PR, Ingle JI. Isotope determination of root canal failure. Oral Surg Oral Med Oral Pathol Oral Radiol Endod. 1995 Sept; 79(9):1100-1104.

31. ElDeeb ME, Thuc-Quyen NT, Jensen JR. The dentinal plug: its effect on confining substances to the canal and on the apical seal. J Endod. 1983 Sept; 9(9):355-359.

32. El-Meligy OA, Avery DR. Comparison of apexification with mineral trioxide aggregate and calcium hydroxide. Pediatr Dent. 2006 May/June; 28(3):248253. 
33. Faria TM. Avaliação do selamento apical após retrobturação com MTA, pasta L \& C e óxido de zinco e eugenol (in vitro). [monografia]. Rio de Janeiro: Curso de Especialização em Endodontia da Odontoclínica Central do Exército; 2003. apud Siqueira Jr. JF, Rôças IN, Lopes HP. Materiais obturadores. In: Lopes HP, Siqueira Jr. JF. Endodontia - biologia e técnica. 2a ed. Rio de Janeiro: Guanabara Koogan; 2004. p.619-643.

34. Fava LRG, Saunders WP. Calcium hydroxide pastes: classification and clinical indications. Int Endod J. 1999 Aug; 32(4):257-282.

35. Felippe MCS, Felippe WT, Marques MM, Antoniazzi JH. The effect of renewal of calcium hydroxide on the apexification and periapical healing of teeth with incomplete root formation. Int Endod J. 2005 July; 38(7):436-442.

36. Felippe WT, Felippe MCS, Rocha JC. The effect of mineral trioxide aggregate on the apexification and periapical healing of teeth with incomplete root formation. Int Endod J. 2006 Jan; 39(1):2-9.

37. Ferreira ALC. Estudo comparativo da capacidade seladora dos cimentos endodônticos, a saber: AH Plus e N-Rickert e da pasta L \& C. [monografia]. Rio de Janeiro: Curso de Especialização em Endodontia do Instituto de Odontologia da PUC-RJ; 2001. apud Siqueira Jr. JF, Rôças IN, Lopes HP. Materiais obturadores. In: Lopes HP, Siqueira Jr. JF. Endodontia - biologia e técnica. 2a ed. Rio de Janeiro: Guanabara Koogan; 2004. p.619-643.

38. Ferris DM, Baumgartner C. Perforation repair comparing two types of mineral trioxide aggregate. J Endod. 2004 June; 30(6):422-424.

39. Fidel RAS, Carvalho RG, Varela CH, Letra A, Fidel SR. Complicated crow fracture: a case report. Braz Dent J. 2006 Jan/Mar; 17(1):83-86.

40. Giuliani V, Baccetti T, Pace R, Pagavino G. The use of MTA in teeth with necrotic pulps and open apices. Dent Traumatol. 2002 Aug; 18(4): 217-221. 
41. Gómez MM. Utilización del agregado de trióxido mineral (MTA) como barrera apical em dientes com el ápice abierto. Endodoncia 2000 Jul-Sept; 18(3):131139.

42. Gutmann JL, Whiterspoon DE. Obturação do sistema de canais radiculares limpo e modelado. In: Cohen S, Burns RC. Caminhos da polpa. 7a ed. Rio de Janeiro: Guanabara Koogan; 2000. p.243-341.

43. Hachmeister DR, Schindler WG, Walker WA, Thomas DD. The sealing ability and retention characteristics of mineral trioxide aggregate in a model of apexification. J Endod. 2002 May; 28(5):386-390.

44. Ham KA, Whiterspoon DE, Gutmann JL, Ravindranatah S, Gait TC, Opperman LA. Preliminary evaluation of BMP-2 expression and histological characteristics during apexification with calcium hydroxide and mineral trioxide aggregate. J Endod. 2005 Apr; 31(4):275-279.

45. Harbert H. Generic tricalcium phosphate plugs: an adjunct in endodontics. J Endod. 1991 Mar; 17(3):131-134.

46. Harbert H. One-step apexification without calcium hydroxide. J Endod. 1996 Dec; 22(12):690-692.

47. Hayashi M, Shimizu A, Ebisu S. MTA for obturation of mandibular central incisors with open apices: case report. J Endod. 2004 Feb; 30(2):120-122.

48. Holland GR. Periapical response to apical plugs of dentin and calcium hydroxide in ferret canines. J Endod. 1984 Feb; 10(2):71-74.

49. Holland R, De Souza V, Nery MJ, de Mello W, Bernabé PFE, Otoboni Filho JA. Tissue reactions following apical plugging of the root canal with infected dentin chips - a histologic study in dogs' teeth. Oral Surg. 1980 Apr; 49(4):366-369. 
50. Holland R, De Souza V, Pannain R, Nery MJ, Bernabé PFE, Mello W. Infiltração marginal de ${ }^{131} \mathrm{INa}$ em obturações de canais radiculares com o auxílio de cones de prata ou guta-percha. Rev Assoc Paul Cirurg Dent. 1975 Mar/Abr; 29(2):36-38.

51. Holland R, De Paula EC, Pereira ANS, De Souza V, Saliba O. Infiltração marginal dos cimentos resinosos. Rev Gaúcha Odontol. 1991 Nov/Dez; 39(6):413-416.

52. Jacobsen EL, Bery PF, BeGole EA. The effectiveness of apical dentin plugs in sealing endodontically treated teeth. J Endod. 1985 July; 11(7):289-293

53. Kratchman SI. Perforation repair and one-step apexification procedures. Dent Clin North Am. 2004 Jan; 48(1):291-307.

54. Kubo CH, Gomes APM, Mancini MNG. In vitro evaluation of apical sealing in root apex treated with demineralization agents and retrofiled with mineral trioxide aggregate through marginal dye leakage. Braz Dent J. 2005 Sept/Dec; 16(3):187-191.

55. Kwak KI, Park DS, Oh S. The effect of obturation timing and thickness of mineral trioxide aggregate matrix on sealing ability. (Abstract) J Endod. 2000 Sept; 26(9):557.

56. Lawley GR, Schindler WG, Walker WA, Kolodrubetz D. Evaluation of ultrasonically placed MTA and fracture resistance with intracanal composite resin in a model of apexification. J Endod. 2004 Mar; 30(3):167-172.

57. Lee SJ, Monsef M, Torabinejad M. Sealing ability of a mineral trioxide aggregate for repair of lateral root perforations. J Endod. 1993 Nov; 19(11):541-544. 
58. Leimburg ML, Angeretti A, Ceruti P, Lendini M, Pasqualini D, Berutti E. MTA obturation of pulpless teeth with open apices: bacterial leakage as detected by polymerase chain reaction assay. J Endod. 2004 Dec; 30(12):883-886.

59. Leonardo MR, Silva LAB. Medicação tópica entre-sessões, “curativo de demora” em biopulpectomia e necropulpectomias I e II. In: Leonardo MR, Leal JM. Endodontia - tratamento de canais radiculares. 3a ed. São Paulo: Panamericana; 1998. p.491-534.

60. Levenstein H. Obturating teeth with wide open apices using mineral trioxide aggregate: a case report. South Afr Dent J. 2002 July; 57(7):270-273.

61. Linsuwanont P. MTA apexification combined with conventional root canal retreatment. Aust Endod J. 2003 Apr; 29(1):45-49.

62. Lopes HP, Costa Filho AS. Tratamento endodôntico dos dentes com rizogênese incompleta e necrose pulpar. Rev Bras Odontol. 1984 Mar/Abr; 41(2):2-12.

63. Lopes HP, Costa Filho AS. Uso do hidróxido de cálcio com veículo oleoso como tampão apical em dentes despolpados com lesões periapicais. Rev Gaúcha Odontol. 1988 Mar/Abr; 36(2):133-138.

64. Lopes HP, Siqueira Jr JF, Estrela C. Tratamento endodôntico em dentes com rizogênese incompleta. In: Lopes HP, Siqueira Jr JF. Endodontia - biologia e técnica. 2a ed. Rio de Janeiro: Guanabara Koogan; 2004. p.707-725.

65. Lynn EA, Einbender S. The use of mineral trioxide aggregate to create an apical stop in previously traumatized adult tooth with blunderbuss canal. N Y State Dent J. 2003 Feb; 69(2):30-32. 
66. Machado SWC. Avaliação do selamento marginal apical promovido pelos cimentos endodônticos EndoFill, Sealer 26 e pela pasta L \& C. [monografia]. Rio de Janeiro: Curso de Especialização em Endodontia da Odontoclínica Central do Exército; 2000. apud Siqueira Jr. JF, Rôças IN, Lopes HP. Materiais obturadores. In: Lopes HP, Siqueira Jr. JF. Endodontia - biologia e técnica. 2a ed. Rio de Janeiro: Guanabara Koogan; 2004. p.619-643.

67. Mangin C, Yesilsoy C, Nissan R, Stevens R. The comparative sealing ability of hydroxiapatite cement, mineral trioxide aggregate, and super ethoxybenzoic acid as root-end filling materials. J Endod. 2003 Apr; 29(4):261-264.

68. Mannocci F, Vichi A, Ferrari M. Sealing ability of several restorative materials used for repair of lateral root perforations. J Endod. 1997 Oct; 23(10):639-641.

69. Maroto M, Barbería E, Planells P, Vera V. Treatment of a non-vital immature incisor with mineral trioxide aggregate (MTA). Dent Traumatol. 2003 June; 19(3):165-169.

70. Matloff IR, Jensen MS, Singer L, Tabibi A. A comparison of methods used in root canal sealability studies. Oral Surg. 1982 Feb; 53(2):203-208.

71. Matt GD, Thorpe JR, Strother JM, McClanahan SB. Comparative study of white and gray mineral trioxide aggregate (MTA) simulating a one-or-two-step apical barrier technique. J Endod. 2004 Dec; 30(12):876-879.

72. Menezes R, Bramante CM, Letra A, Carvalho VG, Garcia RB. Histologic evaluation of pulpotomies in dog using two types of mineral trioxide aggregate and regular and white Portland cements as wound dressings. Oral Surg Oral Med Oral Pathol Oral Radiol Endod. 2004 Sept; 98(3):376-379.

73. Moraes IG. Infiltração marginal nas obturações de canais radiculares em função de agentes irrigadores e cimentos obturadores. [dissertação]. Bauru (SP): Faculdade de Odontologia de Bauru, Universidade de São Paulo; 1981. 
74. Moraes IG. Propriedades físicas de cimentos epóxicos experimentais para obturação de canais radiculares, baseados no AH26. [tese]. Bauru (SP): Faculdade de Odontologia de Bauru, Universidade de São Paulo; 1984.

75. Moraes IG, Moraes FG, Mori GG, Gonçalves SB. Influence of calcium hydroxide on dyes for dentin labeling, analized by means of a new methodology. J Appl Oral Sci. 2005 Jul/Sept; 13(3):218-221.

76. Moraes IG, Nunes E, Berbert A, Duarte MAH, Betti LV. Influência do hidróxido de cálcio e do EDTA na marcação da infiltração marginal de azul de metileno em obturação de canais radiculares. Rev FOB 2000; Jan/Jun; 1/2:3744.

77. Pavan NNO. Análise da infiltração marginal em obturações retrógradas realizadas com polímero de mamona, epóxico experimental, cimento de óxido de zinco e eugenol reforçado (Super-EBA) e ionômero de vidro (FUJI II LC). [dissertação]. Bauru (SP): Faculdade de Odontologia de Bauru, Universidade de São Paulo; 1999.

78. Pitts DL, Jones JE, Oswald RJ. A histological comparison of calcium hydroxide plugs and dentin plugs used for control of gutta-percha root canal filling material. J Endod. 1984 July; 10(7):283-293.

79. Rocha WC. Avaliação dos efeitos da infiltração microbiana, por via coronária, em dentes de cães submetidos à obturação retrógrada com MTA. [tese]. Araçatuba (SP): Faculdade de Odontologia de Araçatuba, Universidade Estadual Paulista; 2003.

80. Rossmeisl R, Reader A, Melfi R, Marquard J. A study of freeze-dried (lyophilized) dentin used as an apical barrier in adult monkey teeth. Oral Surg. 1982 Mar; 53(3):303-310. 
81. Rossmeisl R, Reader A, Melfi R, Marquard J. A study of freeze-dried (lyophilized) cortical bone used as an apical barrier in adult monkey teeth. J Endod. 1982 May; 8(5):219-226.

82. Shabahang S, Torabinejad M. Treatment of teeth with open apices using mineral trioxide aggregate. Pract Periodont Aesthet Dent. 2000 Apr; 12(3):315220.

83. Shabahang S, Torabinejad M, Boyne PP, Abedi H, McMillan P. A comparative study of root-end induction using osteogenic protein-1, calcium hydroxide, and mineral trioxide aggregate in dogs. J Endod. 1999 Jan; 25(1):1-5.

84. Sheehy EC, Roberts GJ. Use of calcium hydroxide for apical barrier formation and healing in non-vital immature permanent teeth: a review. Br Dent J. 1997 Oct; 183(7):241-246.

85. Shimabuko DM. Avaliação “in vitro” do selamento marginal obtido quando do uso de associações de materiais no tratamento de perfurações de furca de molares humanos. [dissertação]. São Paulo (SP): Faculdade de Odontologia, Universidade de São Paulo; 1997.

86. Shipper G, Grossman ES, Botha AJ, Cleaton-Jones PE. Marginal adaptation of mineral trioxide aggregate (MTA) compared with amalgam as a root-end filling material: a low-vacuum (LV) versus high-vacuum (HV) SEM study. Int Endod J. 2004 May; 37(5):325-336.

87. Silva Neto UX. Capacidade seladora e adaptação marginal proporcionadas por alguns materiais quando utilizados em perfurações na região de furca de molares humanos. [dissertação]. Bauru (SP): Faculdade de Odontologia de Bauru, Universidade de São Paulo; 2002. 
88. Silva Neto UX; Moraes IG. Capacidade seladora proporcionada por alguns materiais quando utilizados em perfurações na região de furca de molares humanos extraídos. J Appl Oral Sci. 2003 Jan/Mar; 11(1):27-33.

89. Silva Neto UX et al. Infiltração marginal em obturações retrógradas realizadas com Pro Root MTA, MTA-Angelus e Super-EBA. JBE 2003 Mar/Abr; 4(13):149-152.

90. Siqueira DCR, Taveira AB, Baldi JB, Torres AS, Moraes IG. Avaliação da infiltração bacteriana de cimentos utilizados na retrobturação. [Suplemento] Braz Oral Res. 2004 Set; 18:162.

91. Siqueira Jr. JF, Fraga RC, Garcia PF. Evaluation of sealing ability, pH and flow rate of three calcium hydroxide-based sealers. Endod Dent Traumatol. 1995 Oct; $11(5): 225-228$.

92. Siqueira Jr. JF, Garcia Filho PF. Avaliação “in vitro” das propriedades seladoras de três cimentos endodônticos à base de hidróxido de cálcio. Rev Bras Odontol. $1994 \mathrm{Jan} / \mathrm{Fev} ;$ 51(1):37-40.

93. Siqueira Jr. JF, Lopes HP, Elias CN. Obturação do sistema de canais radiculares. In: Lopes HP, Siqueira Jr JF. Endodontia - biologia e técnica. 2a ed. Rio de Janeiro: Guanabara Koogan; 2004. p.645-692.

94. Siqueira Jr. JF, Rôças IN, Lopes HP. Materiais obturadores. In: Lopes HP, Siqueira Jr. JF. Endodontia - biologia e técnica. 2a ed. Rio de Janeiro: Guanabara Koogan; 2004. p.619-643.

95. Sluyk SR, Moon PC, Hartwell GR. Evaluation of setting properties and retention characteristics of mineral trioxide aggregate when used as a furcation perforation repair material. J Endod. 1998 Nov; 24(11):768-771. 
96. Spängberg LSW, Acierno TG, Cha BY. Influence of entrapped air on the accuracy of leakage studies using dye penetration methods. J Endod. 1989 Nov; 15(11):548-551.

97. Stabholtz A, Shani J, Friedman S, Abed J. Marginal adaptation of retrograde fillings and its correlation with sealability. J Endod. 1985 May;11(5):218-223.

98. Starkey DL, Anderson RW, Pashley DH. An evaluation of the effect of methylene blue dye pH on apical leakage. J Endod. 1993 Sept; 19(9): 435-439

99. Steinig TH, Regan JD, Gutmann JL. The use and predictable placement of mineral trioxide aggregate in one-visit apexification cases. Aust Endod J. 2003 Apr; 29(1):34-42.

100. Stuart CH, Schwartz SA, Beeson TJ. Reinforcement of immature roots with a new resin filling material. J Endod. 2006 Apr; 32(4):350-353.

101. Tagger M, Tamse A, Katz A, Korzen BH. Evaluation of the apical seal produced by a hybrid root canal filling method, combining lateral condensation and thermatic compaction. J Endod. 1984 July; 10(7): 299-303.

102. Tang HM, Torabinejad M, Kettering JD. Leakage evaluation of root end filling materials using endotoxina. J Endod. 2002 Jan; 28(1):5-7.

103. Tanomaru Filho M, Figueiredo FA, Tanomaru JMG. Effect of diferent dye solutions on the evaluation of the sealing ability of mineral trioxide aggregate. Bras Oral Res. 2005 Apr/June; 19(2):119-122.

104. Tittle K, Farley J, Linkhardt T, Torabinejad M. Apical closure induction using bone growth factors and mineral trioxide aggregate. [Abstract] J Endod. 1996; 22(4):198. 
105. Torabinejad M, Chivian N. Clinical applications of mineral trioxide aggregate. J Endod. 1999 Mar; 25(3):197-205.

106. Torabinejad M, Higa RK, McKendry DJ, Pitt Ford TR. Dye leakage of four root end filling materials: effects of blood contamination. J Endod. 1994 Apr; 20(4):159-163.

107. Torabinejad M, Hong CU, McDonald F, Pitt Ford TR. Physical and chemical properties of a new root-end filling material. J Endod. 1995 July; 21(7):349353.

108. Torabinejad M, Rastegar AF, Kettering JD, Pitt Ford TR. Bacterial leakage of mineral trioxide aggregate as a root-end filling material. J Endod. 1995 Mar; 21(3):109-112.

109. Torabinejad M, Smith PW, Kettering JD, Pitt Ford TR. Comparative investigation of marginal adaptation of mineral trioxide aggregate and other commonly used root-end filling materials. J Endod. 1995 June; 21(6):295-299.

110. Torabinejad M, Watson TF, Pitt Ford TR. Sealing ability of a mineral trioxide aggregate when used as a root end filling material. J Endod. 1993 Dec; 19(12):591-595.

111. Valois CRA, Costa Jr ED. Influence of the thickness of mineral trioxide aggregate on sealing ability of root-end filling in vitro. Oral Surg Oral Med Oral Pathol Oral Radiol Endod. 2004 Jan; 97(1):108-111.

112. Vasconcelos BC. Avaliação de algumas propriedades físico-químicas de cimentos retro-obturadores à base de agregado trióxido mineral e de um cimento epóxico experimental. [dissertação]. Bauru (SP): Faculdade de Odontologia de Bauru, Universidade de São Paulo; 2006. 
113. Vinholes JIAM. Tratamento das perfurações na região de furca: estudo comparativo. [dissertação]. Pelotas (RS): Faculdade de Odontologia, Universidade Federal de Pelotas; 2000.

114. Vizgirda PJ, Liewehr FR, Patton WR, McPherson JC, Buxton TB. A comparison of laterally condensed gutta-percha, thermoplasticized gutta-percha, and mineral trioxide aggregate as root canal filling materials. J Endod. 2004 Feb; 30(2):103-106.

115. Weisenseel JA, Lamar Hicks M, Pelleu GB. Calcium hydroxide as an apical barrier. J Endod. 1987 Jan; 13(1):1-5.

116. Whiterspoon DE, Ham K. One-visit apexification: technique for inducing rootend barrier formation in apical closures. Pract Proced Aesthet Dent. 2001; 13(6):455-460.

117. Wu MK, Kontakiotis EG, Wesselink PR. Decoloration of $1 \%$ methylene blue solution in contact with dental filling materials. J Dent. 1998 Sept; 26(7):585589.

118. Wu MK, Wesselink PR. Endodontic leakage studies reconsidered. Part I. Methodology, application and relevance. Int Endod J. 1993 Jan; 26(1):37-43.

119. Wucherpfennig AL, Green DB. Mineral trioxide aggregate vs Porland cement: two biocompatible filling materials. (Abstract) J Endod. 1999; 25: 308.

120. Wylie Brandell D, Torabinejad M, Bakland LK, Lessard GM. Demineralized dentin, hydroxilapatite and dentin chips as apical plugs. Endod Dent Traumatol. 1986 Oct; 2(5):210-214.

121. Xavier CB, Weismann R, Oliveira MG, Demarco FF, Pozza DH. Root-end filling materials: apical microleakage and marginal adaptation. J Endod. 2005 July; 31(7):539-542. 
122. Xu Q, Lin JQ, Gu HJ, Liu JW. Clinical management of open apices teeth with mineral trioxide aggregate (MTA) as apical barrier in adults. Hua Xi Kou Qiang Yi Xue Za Zhi [abstract na internet] 2006 Aug;24(4):312-314. [citado em 10 out. 2006]. Disponível em http://www.ncbi.nlm.nih.gov/entrez/query.fcgi?db=pubmed\&cmd=Retrieve\&do pt=AbstractPlus\&list_uids=16999347\&query_hl=2\&itool=pubmed_docsum.

123. Xu Q, Lin JQ, Huang F, Liu JW. Treatment with open apices using mineral trioxide aggregate as apical barrier. Shangai Kuo Qiang Yi Xue [abstract na internet] 2006 Feb;15(1):7-10. [citado em 10 out. 2006]. Disponível em http://www.ncbi.nlm.nih.gov/entrez/query.fcgi?db=pubmed\&cmd=Retrieve\&do $\mathrm{pt}=$ AbstractPlus\&list_uids=16525599\&query_hl=2\&itool=pubmed_docsum.

124. Yamashita JC, Kuga MC, Fraga SC, Duarte MAH, Tanomaru Filho M. Cimento endodôntico AH Plus como material retroobturador: avaliação da capacidade de selamento apical, in vitro - relato de caso clínico. J Bras Odontol Clin. 1999; 18(3):70-73.

125. Yee RDJ, Newton CW, Patterson SS, Swartz ML. The effect of canal preparation on the formation and leakage characteristics of the apical dentin plug. J Endod. 1985 July; 10(7):308-317.

126. Yeung P, Liewehr FR, Moon PC. A quantitative comparison of the fill density of MTA produced by two placement techniques. J Endod. 2006 May; 32(5):456-459.

127. Yoshimura M, Marshall J, Tinkle JS. In vitro quantification of the apical sealing ability of retrograde amalgam fillings. J Endod. 1990 Jan; 16(1):9-12. 
ABSTRACT 


\section{ABSTRACT \\ Analysis of the sealing ability and marginal adaptation of apical plugs fabricated with different materials, under the influence of three root canal filling techniques}

This study evaluated the sealing ability and marginal adaptation of apical plugs fabricated with different materials, under the influence of three root canal filling techniques. The study sample was composed of 120 single-rooted permanent teeth with a single canal, either maxillary or mandibular, with intact roots and completely formed apices. After coronal opening, root canal preparation was performed by the crown-down technique with Gates Glidden burs in decreasing order, from bur \#5 to \#1; the latter always surpassed the apical foramen in $1 \mathrm{~mm}$. After this procedure, the root canals were enlarged with $\mathrm{K}$ files \#50 to \#90, therefore standardizing the foramen diameter. During instrumentation, all files surpassed the apical foramen in $1 \mathrm{~mm}$. Afterwards, the external root surfaces were impermeabilized by application of one coat of Araldite and two coats of nail enamel. Following, the teeth were divided into 4 groups with 30 specimens each, according to the materials employed to fabricate the apical plugs, with 5-mm thickness: Group 1 - L \& C paste; Group 2 - gray MTA-Angelus ${ }^{\mathrm{TM}}$ sealer; Group 3 - CPM ${ }^{\mathrm{TM}}$ sealer; and Group 4 - MBPc sealer. Each group was then divided into three subgroups with 10 teeth each, according to the root canal filling technique adopted: lateral condensation, Tagger hybrid technique, and Ultrafil system. Then, the 10 teeth from each subgroup, properly labeled, were immersed into 0.2\% Rhodamine B, pH 7.0 and placed in an oven at $37^{\circ} \mathrm{C}$ for 48 hours. After rinsing and removal of the impermeable coat, the teeth were longitudinally worn with carborundum discs on the mesial or distal aspect, with a view to expose the apical plug and root canal filling. Analysis of marginal leakage was performed with aid of digitized photographs on the software Image Tool 3.0. Leakage was measured on the most extensive trace of dye leakage at the interface between the apical plug and dentinal wall, from the most apical to the most cervical portions of material. The marginal adaptation of materials employed for fabrication of the apical plug to the dentinal walls was investigated on the same teeth submitted to the 
0.2\% Rhodamine B leakage test, except for the teeth in Group 1 (L \& C paste). For that purpose, the 90 specimens in Groups 2, 3 and 4 were transversely sectioned at $7 \mathrm{~mm}$ from the apex. These segments were gold-sputtered and analyzed by scanning electron microscopy, with achievement of photomicrographs at 35X and 150X magnifications. For analysis of the marginal adaptation of sealers, the photomicrographs at $35 \mathrm{X}$ magnification were analyzed on the software Image Tool 3.0 and the extent of misfit was measured linearly, in micrometers. The results achieved for both leakage and marginal adaptation analyses were tabulated and statistically analyzed by the KruskalWallis and Dunn's tests. The results revealed that the sealer MBPc exhibited the lowest values of leakage of $0.2 \%$ Rhodamine $B$, with statistically significant difference compared to the other materials; the sealer $\mathrm{CPM}^{\mathrm{TM}}$ presented the best results as to adaptation to the root canal walls, yet without statistical significance; the three root canal filling techniques employed did not have any influence on the sealing ability or the adaptation of apical plugs.

Key words: Sealing ability. Marginal adaptation. Apical plug. 